\title{
A Highly Efficient Nickel-Catalyzed Cross-Coupling of Succinic and Glutaric Anhydrides with Organozinc Reagents
}

\author{
Eric A. Bercot and Tomislav Rovis* \\ Department of Chemistry, Colorado State University \\ Fort Collins, Colorado 80523
}

Supporting Information

General Methods. All reactions were carried out under an atmosphere of argon in flame-dried glassware with magnetic stirring. Tetrahydrofuran, diethylether, and dichloromethane were degassed with argon and passed through two columns of neutral alumina. Toluene was degassed with argon and passed through one column of neutral alumina and one column of Q5 reactant. Column chromatography was performed on EM Science silica gel 60 (230-400 mesh). Thin layer chromatography was performed on EM Science $0.25 \mathrm{~mm}$ silica gel $60-\mathrm{F}$ plates. Visualization was accomplished with UV light, $\mathrm{KMnO}_{4}$, aqueous ceric ammonium molybdate, or bromocresol green dips followed by heating.

Anhydrides 1, 6, 8, 18, 22, 26, 32, and 42 were purchased from Aldrich Chemical Co. and used without purification. Anhydrides 30, 54, and 56 were purchased from Rieke Metals Inc. and used without further purification. Anhydrides 38, 44, and 60 were prepared from the corresponding commercially available diacids (Aldrich) using the cyclization protocol below. Saturated anhydrides 16, 20, and 24 were prepared by hydrogenation $\left(\mathrm{H}_{2}, \mathrm{Pd} / \mathrm{C}\right.$, EtOAc) of the corresponding unsaturated anhydrides. Anhydrides $\mathbf{1 0},{ }^{1} \mathbf{1 2},{ }^{2} \mathbf{1 4},{ }^{3} \mathbf{2 8},{ }^{4} \mathbf{3 6},{ }^{5} \mathbf{5 0},{ }^{6}$ and $\mathbf{5 2}^{7}$ were prepared by literature methods. $\mathrm{Ni}(\mathrm{COD})_{2}$ was purchased from Strem Chemical, Inc. and used without further purification.

Melting points were measured with a MelTemp II melting point apparatus outfitted with a Fluke 51 thermocouple and are uncorrected. Infrared spectra were obtained on a Nicolet Avatar 320 FT-IR spectrometer. ${ }^{1} \mathrm{H}$ NMR and spectra were recorded on a Varian 300, 400, or $500 \mathrm{MHz}$ spectrometer at ambient temperature. Data

\footnotetext{
${ }^{1}$ Zhu, Z.; Espenson, J. H. J. Am. Chem. Soc. 1997, 119, 3507-3512.

${ }^{2}$ Hiroshi, S.; Ohtsuka, H.; Migita, T. J. Am. Chem. Soc. 1988, 110, 2014-2015.

${ }^{3}$ Larter, R. M.; Craig, R. E.; Craig, A. C.; Mundy, B. P. J. Org. Chem. 1977, 42, 1259-1261.

${ }^{4}$ Schueler, P. E.; Rhodes, Y. E. J. Org. Chem. 1974, 39, 2063-2069.

${ }^{5}$ Dobashi, Y.; Hara, S. J. Org. Chem. 1987, 52, 2490-2496.

${ }^{6}$ Lewer, P.; MacMillan, J. J. Chem. Soc., Perkin Trans. I 1983, 7, 1417-1420.

${ }^{7}$ Paquette, L. A.; Boulet, S. L. Synthesis 2002, 888-894.
} 
are reported as follows: chemical shift in parts per million $(\delta, \mathrm{ppm})$ from an internal standard [tetramethylsilane (TMS) or chloroform $\left(\mathrm{CHCl}_{3}\right)$ taken as $7.26 \mathrm{ppm}$ ], multiplicity $(\mathrm{s}=$ singlet, $\mathrm{d}=$ doublet, $\mathrm{t}=$ triplet, $\mathrm{q}=$ quartet, and $\mathrm{m}=$ multiplet $)$, integration, and coupling constant $(\mathrm{Hz}) .{ }^{13} \mathrm{C}$ NMR were recorded on a Varian 75,100 , or $125 \mathrm{MHz}$ spectrometer at ambient temperature. Chemical shifts are reported in ppm from $\left(\mathrm{CDCl}_{3}\right)$ taken as $77.0 \mathrm{ppm}$. Mass spectra were obtained on Fisons VG Autospec. Gas chromatography was performed on a Varian Cp 3800 gas chromatograph equipped with a flame ionization detector using a Chromopack CP-Sil 8 CB (15 M X .25 mm) capillary column.

\section{Synthesis of Starting Materials}<smiles>O=C(O)C(O)C(O)C(=O)O</smiles>

S1

$$
\begin{aligned}
& \text { 1) } \mathrm{H}_{2} \mathrm{SO}_{4}, \mathrm{Ac}_{2} \mathrm{O}, \Delta \\
& \text { 2) TFAA, } \mathrm{CH}_{2} \mathrm{Cl}_{2}
\end{aligned}
$$

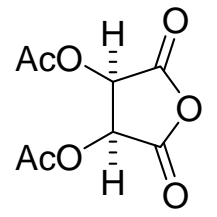

34

meso-3,4-diacetoxysuccinic anhydride (34). A flame-dried round bottom flask equipped with a reflux condenser under argon was charged with $170 \mathrm{mg}(1.13 \mathrm{mmol})$ of meso-tartaric acid (S1) in $2 \mathrm{~mL}$ of $\mathrm{Ac}_{2} \mathrm{O}$ and 2 drops of conc. $\mathrm{H}_{2} \mathrm{SO}_{4}$, then brought to reflux for 10 minutes. Upon cooling to room temperature the reaction was diluted with $\mathrm{CH}_{2} \mathrm{Cl}_{2}(20 \mathrm{~mL})$ and extracted with sat. aq. $\mathrm{Na}_{2} \mathrm{CO}_{3}(2 \mathrm{X} 5 \mathrm{~mL})$. The basic layers were combined and acidified with conc. $\mathrm{HCl}$. The resulting aqueous layer was extracted with EtOAc (3 X $10 \mathrm{~mL}$ ), the organic layers were combined, washed with brine, dried over $\mathrm{MgSO} 4$, filtered and concentrated to provide crude acylated diacid. The crude diacid was suspended in $4 \mathrm{~mL}$ of $\mathrm{CH}_{2} \mathrm{Cl}_{2}$ and cooled to $0{ }^{\circ} \mathrm{C}$. $1.0 \mathrm{~mL}$ (7.2 mmol) of trifluoroacetic anhydride was then added dropwise via syringe. The reaction was stirred for $1 \mathrm{~h}$ at $0{ }^{\circ} \mathrm{C}$ then concentrated to provide $183 \mathrm{mg}(75 \%)$ of the desired anhydride 34 as a colorless oil that crystallized on standing: $\mathrm{mp}=67-71^{\circ} \mathrm{C}\left(\mathrm{CH}_{2} \mathrm{Cl}_{2}\right) ; \mathrm{R}_{\mathrm{f}}=0.12(95: 5$ $\mathrm{CH}_{2} \mathrm{Cl}_{2} / \mathrm{MeOH}$ ); ${ }^{1} \mathrm{H}$ NMR (400 MHz, CDCl 3 ) $\delta 5.52$ (s, 2H), 2.20 (s, 6H); ${ }^{13} \mathrm{C}$ NMR (100 $\mathrm{MHz}, \mathrm{CDCl}_{3}$ ) d 169.2, 164.9, 65.9, 19.6; IR ( $\mathrm{NaCl}$, dep from $\left.\mathrm{CDCl}_{3}\right)$ 2947, 1802, 1755, $1377,1215,1038 \mathrm{~cm}^{-1}$. 

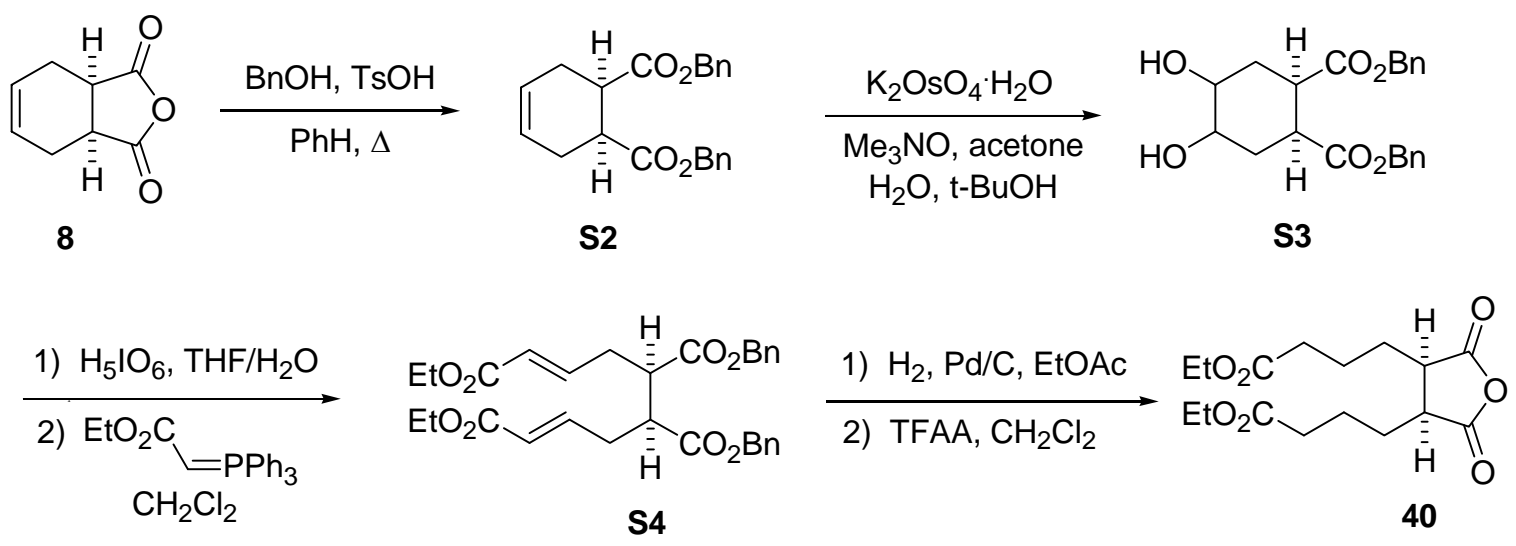

meso-3,4-di-(1-ethoxycarbonyl-propyl)-succinic anhydride (40). A flame-dried round bottom flask under argon was charged with $2.00 \mathrm{~g}$ (13.1 mmol) of anhydride $\mathbf{8}$ and 249 $\mathrm{mg}$ (1.31 mmol) of p-toluenesulfonic acid monohydrate in $40 \mathrm{~mL}$ of dry benzene. 2.8 $\mathrm{mL}$ ( $27 \mathrm{mmol}$ ) of benzyl alcohol were added via syringe then the reaction was fitted with a Dean-Stark apparatus and brought to reflux for $13 \mathrm{~h}$. Upon cooling the reaction was diluted with $\mathrm{Et}_{2} \mathrm{O}(50 \mathrm{~mL})$ and washed sequentially with sat. aq. $\mathrm{NaHCO}_{3}$ and brine, dried over $\mathrm{MgSO}_{4}$, filtered and concentrated to provide $4.28 \mathrm{~g}$ (93 \%) of meso-diester S2 as a colorless oil. A round bottom flask was charged with $1.02 \mathrm{~g}(2.90 \mathrm{mmol})$ of diester S2 in $7 \mathrm{~mL}$ of $6: 1$ acetone/water. $660 \mathrm{mg}(5.94 \mathrm{mmol})$ of trimethylamine oxide were then added in one portion followed by $11 \mathrm{mg}(0.035 \mathrm{mmol})$ potassium osmate dihydrate. 1 $\mathrm{mL}$ of $t-\mathrm{BuOH}$ was then added and the reaction stirred for $14 \mathrm{~h}$ at ambient temperature. The reaction was quenched with $5 \mathrm{~mL}$ of sat. aq. $\mathrm{NaHSO}_{3}$ and allowed to stir for $1 \mathrm{~h}$ before the addition of $50 \mathrm{~mL}$ of water. The resulting aqueous reaction mixture was extracted with $\mathrm{CH}_{2} \mathrm{Cl}_{2}$ (3 X $50 \mathrm{~mL}$ ). The organic extracts were combined, washed with brine, dried over $\mathrm{Na}_{2} \mathrm{SO}_{4}$, decanted and concentrated to yield the crude diol that was purified by column chromatography $\left(97: 3 \mathrm{CH}_{2} \mathrm{Cl}_{2} / \mathrm{MeOH}\right)$ gave $877 \mathrm{mg}(79 \%)$ of diol S3 as a viscous oil. A round bottom flask was charged with $590 \mathrm{mg}(1.53 \mathrm{mmol})$ of diol in $10 \mathrm{~mL}$ of $4: 1 \mathrm{THF} /$ water. $420 \mathrm{mg}$ (1.85 mmol) of periodic acid were added in one portion and the reaction stirred for $1 \mathrm{~h}$ at ambient temperature. The reaction was diluted with water $(20 \mathrm{~mL})$ and extracted with $\mathrm{Et}_{2} \mathrm{O}(3 \mathrm{X} 15 \mathrm{~mL})$. Organic extracts were combined, washed with brine, dried over $\mathrm{MgSO}_{4}$, filtered, and concentrated to provide crude dialdehyde as an oil that was directly used in the next step. A flame-dried round bottom flask was charged with crude dialdehyde in $15 \mathrm{~mL}$ of $\mathrm{CH}_{2} \mathrm{Cl}_{2} \cdot 1.61 \mathrm{~g}$ (4.62 $\mathrm{mmol}$ ) of (carbethoxyethylidene)triphenylphosphorane were added in one portion and the reaction stirred for $14 \mathrm{~h}$ at ambient temperature. Upon completion the reaction was diluted with EtOAc $(50 \mathrm{~mL})$ and washed with sat. aq. $\mathrm{NH}_{4} \mathrm{Cl}$, sat. aq. $\mathrm{NaHCO}_{3}$, brine, dried over MgSO4, filter, and concentrated providing crude diester. Purification by column chromatography (4:1 Hex/EtOAc) providing $337 \mathrm{mg}$ (42\% from diol) of the desired diester $\mathbf{S} \mathbf{4}$ as a colorless oil. A round bottom flask was charged with $337 \mathrm{mg}$ $(0.654 \mathrm{mmol})$ of diester $\mathbf{S} 4 \mathrm{in} 10 \mathrm{~mL}$ of EtOAc. Argon was passed through the solution for $5 \mathrm{~min}$. before the addition of $30 \mathrm{mg}(0.028 \mathrm{mmol} \mathrm{Pd})$ of $10 \%(\mathrm{wt}) \mathrm{Pd} / \mathrm{C}$. The reaction vessel was placed under an atmosphere of $\mathrm{H}_{2}$ and stirred for $12 \mathrm{~h}$ at ambient temperature. The reaction mixture was passed through a celite pad that was thoroughly washed with EtOAc and the filtrate concentrated giving crude diacid. Diacid was 
suspended in $10 \mathrm{~mL}$ of $\mathrm{CH}_{2} \mathrm{Cl}_{2}$ and cooled to $0{ }^{\circ} \mathrm{C}$ before the addition of $0.20 \mathrm{~mL}(1.4$ mmol) of trifluoroacetic anhydride via syringe. The reaction was stirred for $1 \mathrm{~h}$ at $0{ }^{\circ} \mathrm{C}$ at which time it had turned homogeneous. The reaction was concentrated supplying $200 \mathrm{mg}$ (94 \% from S4) anhydride 40 as an oil that crystallized upon standing: $\mathrm{mp}=105-106{ }^{\circ} \mathrm{C}$ $\left(\mathrm{CH}_{2} \mathrm{Cl}_{2}\right) ; \mathrm{R}_{\mathrm{f}}=0.20(1: 1 \mathrm{Hex} / \mathrm{EtOAc}) ;{ }^{1} \mathrm{H} \mathrm{NMR}\left(400 \mathrm{MHz}, \mathrm{CDCl}_{3}\right) \delta 4.12$ (q, 4H, $J=7.0$ $\mathrm{Hz}$ ), 2.72-2.70 (m, 2H), 2.35-2.31 (m, 4H), 1.76-1.50 (m, 8H), 1.24 (t, 6H, $J=7.0 \mathrm{~Hz})$;

${ }^{13} \mathrm{C}$ NMR $\left(100 \mathrm{MHz}, \mathrm{CDCl}_{3}\right) \delta 178.5,173.5,60.6,40.1$, 33.8, 29.0, 22.8, 14.2; IR $(\mathrm{NaCl}$, dep from $\mathrm{CDCl}_{3}$ ) 2989, 2958, 1732, 1697, 1416, 1292, $1196 \mathrm{~cm}^{-1}$; HRMS (FAB+) calcd for $\mathrm{C}_{16} \mathrm{H}_{25} \mathrm{O}_{7}$, 329.1600. Found 329.1608.<smiles>CCOC(=O)CC(O)CC(=O)OCC</smiles>

S5

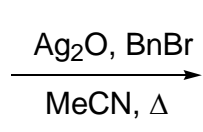

$\mathrm{MeCN}, \Delta$

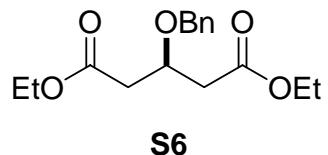

S6

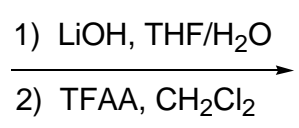

2) TFAA, $\mathrm{CH}_{2} \mathrm{Cl}_{2}$

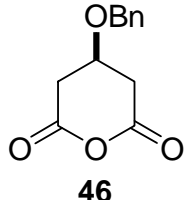

46

meso-4-(benzyloxy)-glutaric anhydride (46). A flame dried round bottom flask equipped with a reflux condenser under an argon atmosphere was charged with $1.77 \mathrm{~g}$ (7.64 mmol) of $\mathrm{Ag}_{2} \mathrm{O}$ suspended in $15 \mathrm{~mL}$ of freshly distilled MeCN. $1.00 \mathrm{~g}$ (4.91 mmol) of diethyl-3-hydroxy glutarate (S5) was added via syringe followed by the addition of $2.02 \mathrm{~g}$ (11.8 mmol) of benzyl bromide. The reaction was covered with foil and brought to reflux for $14 \mathrm{~h}$. Upon cooling, the reaction was filtered through a celite pad that was washed with EtOAc. The filtrate was concentrated and purified by column chromatography (9:1 Hex/EtOAc) yielding $351 \mathrm{mg}$ (24\%) of the desired diester $\mathbf{S 6}$ as a colorless oil. A round bottom flask was charged with $351 \mathrm{mg}(1.19 \mathrm{mmol})$ of diester S6 in $8 \mathrm{~mL}$ of 3:1 THF/water. $114 \mathrm{mg}$ ( $4.76 \mathrm{mmol})$ of LiOH was added in one portion and the reaction stirred at ambient temperature for $15 \mathrm{~h}$. $20 \mathrm{~mL}$ of water were added and the aqueous layer separated and washed with EtOAc $(1$ X $30 \mathrm{~mL})$. The aqueous layer was acidified with conc. $\mathrm{HCl}$ and extracted with EtOAc (3 X $15 \mathrm{~mL})$. Organic extracts were combined, washed with brine, dried over $\mathrm{MgSO}_{4}$, filtered, and concentrated to yield 248 mg (87 \%) of diacid as a white solid. $248 \mathrm{mg}(1.04 \mathrm{mmol})$ of diacid was suspended in 7 $\mathrm{mL}$ of $\mathrm{CH}_{2} \mathrm{Cl}_{2}$ and cooled to $0{ }^{\circ} \mathrm{C}$ before the addition of $0.30 \mathrm{~mL}(2.2 \mathrm{mmol})$ of trifluoroacetic anhydride via syringe. The reaction was stirred for $1 \mathrm{~h}$ at $0{ }^{\circ} \mathrm{C}$ and warmed to ambient temperature and stirred an additional $1 \mathrm{~h}$ before being concentrated. The crude anhydride was dissolved in $\mathrm{CHCl}_{3}(30 \mathrm{~mL})$ and washed with $5 \%$ aq. $\mathrm{NaHCO}_{3}$ (1 X $20 \mathrm{~mL}$ ). The organic layer was dried over $\mathrm{MgSO}_{4}$ and concentrated yielding 203 mg (87\%) of anhydride 46 as a white solid: $\mathrm{mp}=79-80{ }^{\circ} \mathrm{C}\left(\mathrm{CHCl}_{3}\right) ; \mathrm{R}_{\mathrm{f}}=0.27(1: 1$ Hex/EtOAc); ${ }^{1} \mathrm{H}$ NMR (400 MHz, $\mathrm{CDCl}_{3}$ ) $\delta$ 7.39-7.28 (m, 5H), 4.58 (s, 2H), 4.08 (dddd, $1 \mathrm{H}, J=3.4$, 3.4, 3.4, 3.4 Hz), 3.11 (dd, 2H, $J=16.6$, $3.6 \mathrm{~Hz}$ ), 2.74 (dd, 2H, $J=16.6,3.0$ $\mathrm{Hz}) ;{ }^{13} \mathrm{C} \mathrm{NMR}\left(100 \mathrm{MHz}, \mathrm{CDCl}_{3}\right) \delta 164.6,136.4,128.7,128.3,127.7,70.9,66.8,35.8$; IR (NaCl, dep from $\mathrm{CDCl}_{3}$ ) 2943, 2908, 1813, 1778, 1759, 1346, 1250, 1072, $1034 \mathrm{~cm}^{-1}$; HRMS (FAB+) calcd for $\mathrm{C}_{12} \mathrm{H}_{13} \mathrm{O}_{4}, 221.0814$. Found 221.0809 . 

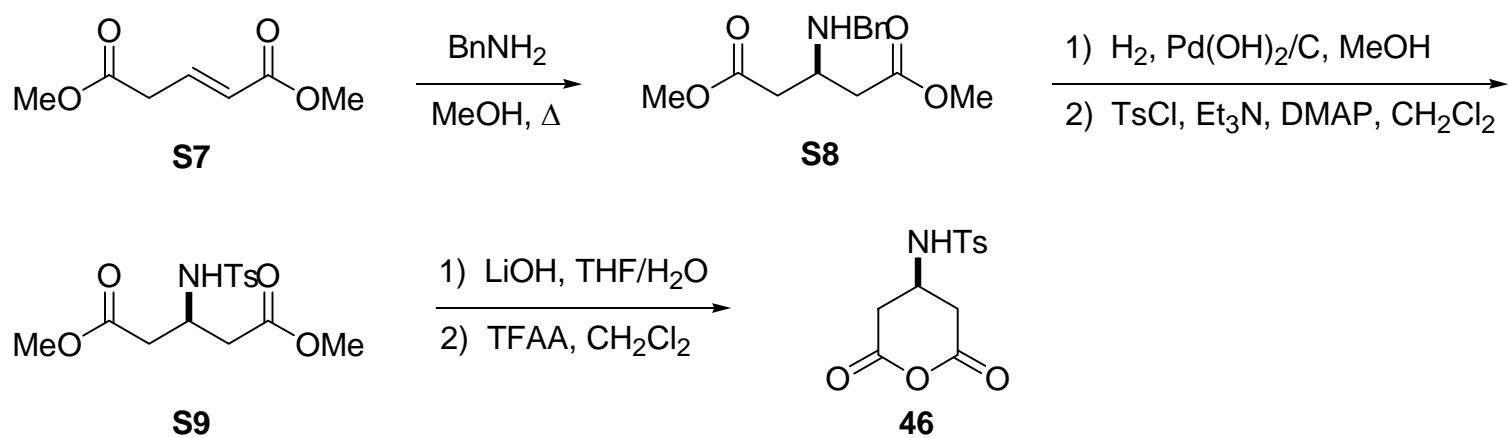

meso-4-(p-toluenesulfonamide)-glutaric anhydride (48). A flame-dried round bottom flask equipped with a reflux condenser under argon was charged with $0.70 \mathrm{~mL}$ (5.0 mmol) of dimethyl glutaconate S7 in $6 \mathrm{~mL}$ of distilled $\mathrm{MeOH}$. $0.60 \mathrm{~mL}$ (5.5 mmol) of benzyl amine was added via syringe and the reaction brought to reflux for $20 \mathrm{~h}$. The reaction was concentrated and purified by column chromatography (4:1 Hex/EtOAc) providing $1.02 \mathrm{~g}$ (77\%) of conjugate addition product $\mathbf{S 8}$ as a light brown oil. A round bottom flask was charged with $1.02 \mathrm{~g}$ ( $3.84 \mathrm{mmol}$ ) of benzylamine diester $\mathbf{S 8}$ in $15 \mathrm{~mL}$ of $\mathrm{MeOH}$. After passing argon through the solution for $15 \mathrm{~min} ., 107 \mathrm{mg}(0.0770 \mathrm{mmol}$ $\mathrm{Pd}(\mathrm{OH})_{2}, 50 \%$ wt. $\left.\mathrm{H}_{2} \mathrm{O}\right)$ of $20 \% \mathrm{Pd}(\mathrm{OH})_{2} / \mathrm{C}$ was added in one portion and the reaction was placed under an atmosphere of $\mathrm{H}_{2}$ and stirred at ambient temperature for $12 \mathrm{~h}$. The reaction was filtered through a celite pad that was thoroughly washed with EtOAc. The filtrate was concentrated to yield $657 \mathrm{mg}$ (98 \%) of amine as a colorless oil. The amine was immediately taken on to the next step. A flame-dried round bottom flask was placed under argon and charged with $657 \mathrm{mg}$ ( $3.75 \mathrm{mmol}$ ) of amine in $8 \mathrm{~mL}$ of $\mathrm{CH}_{2} \mathrm{Cl}_{2} .1 .50$ $\mathrm{mL}(10.8 \mathrm{mmol})$ of triethylamine via syringe was followed by addition of $48 \mathrm{mg}(0.39$ mmol) of 4-dimethylamino pyridine. The reaction was cooled to $0{ }^{\circ} \mathrm{C}$ and $789 \mathrm{mg}(4.14$ $\mathrm{mmol}$ ) of $p$-toluenesulfonyl chloride was added in one portion. After $15 \mathrm{~min}$. the reaction was warmed to ambient temperature and stirred an additional $1.5 \mathrm{~h}$. The reaction was diluted with $\mathrm{CH}_{2} \mathrm{Cl}_{2}(50 \mathrm{~mL})$, washed with sat. aq. $\mathrm{NH}_{4} \mathrm{Cl}$, sat. aq. $\mathrm{NaHCO}_{3}$, dried over $\mathrm{MgSO}_{4}$, filtered and concentrated to provide $1.14 \mathrm{~g}$ (93 \%) of the desired product S9 as a white solid. A round bottom flask was charged with $1.14 \mathrm{~g}$ (3.46 mmol) of diester S9 in $20 \mathrm{~mL}$ of 3:1 THF/water. $359 \mathrm{mg}(15.0 \mathrm{mmol})$ of $\mathrm{LiOH}$ was added in one portion and the reaction stirred at ambient temperature for $15 \mathrm{~h} .50 \mathrm{~mL}$ of water were added and the aqueous layer separated and washed with EtOAc $(1 \mathrm{X} 30 \mathrm{~mL})$. The aqueous layer was acidified with conc. $\mathrm{HCl}$ and extracted with EtOAc (3 X $25 \mathrm{~mL})$. Organic extracts were combined, washed with brine, dried over $\mathrm{MgSO}_{4}$, filtered, and concentrated to yield 945 mg (91 \%) of diacid as a white solid. $945 \mathrm{mg}$ (3.14 mmol) of diacid was suspended in 20 $\mathrm{mL}$ of $\mathrm{CH}_{2} \mathrm{Cl}_{2}$ and cooled to $0{ }^{\circ} \mathrm{C}$ before the addition of $0.90 \mathrm{~mL}(6.5 \mathrm{mmol})$ of trifluoroacetic anhydride via syringe. The reaction was stirred for $1 \mathrm{~h}$ at $0{ }^{\circ} \mathrm{C}$ and warmed to ambient temperature and stirred an additional $2 \mathrm{~h}$ before being concentrated, yielding $870 \mathrm{mg}$ (98\%) of anhydride 48 as a white solid: $\mathrm{mp}=161-164{ }^{\circ} \mathrm{C}\left(\mathrm{CH}_{2} \mathrm{Cl}_{2}\right) ; \mathrm{R}_{\mathrm{f}}$ $=0.26$ (1:1 Hex/EtOAc); ${ }^{1} \mathrm{H}$ NMR (400 MHz, d ${ }_{6}$-DMSO) $\delta 8.20(\mathrm{~d}, 1 \mathrm{H}, J=4.7 \mathrm{~Hz}), 7.71$ (d, $2 \mathrm{H}, J=7.9 \mathrm{~Hz}$ ), 7.43 (d, 2H, $J=7.9 \mathrm{~Hz}$ ), 3.71 (m, 1H), 2.84 (dd, 2H, $J=16.8,4.3$ $\mathrm{Hz}$ ), 2.74 (dd, $2 \mathrm{H}, J=17.1,6.0 \mathrm{~Hz}), 2.40(\mathrm{~s}, 3 \mathrm{H}) ;{ }^{13} \mathrm{C}$ NMR (100 MHz, $\left.\mathrm{d}_{6}-\mathrm{DMSO}\right) \delta$ 165.8, 143.2, 137.2, 129.9, 126.6, 43.6, 35.7, 21.0; IR ( $\mathrm{NaCl}$, dep from $\mathrm{CDCl}_{3}$ ) 3252, 2920, 1817, 1767, 1335, 1161, 1080, $1041 \mathrm{~cm}^{-1}$; HRMS (FAB+) calcd for $\mathrm{C}_{12} \mathrm{H}_{14} \mathrm{NO}_{5} \mathrm{~S}$, 284.0593. Found 284.0600. 


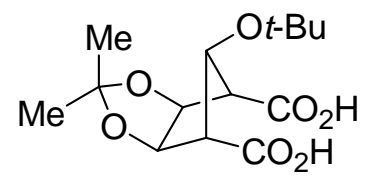

S10

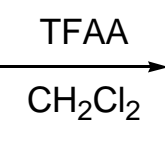

$\mathrm{CH}_{2} \mathrm{Cl}_{2}$

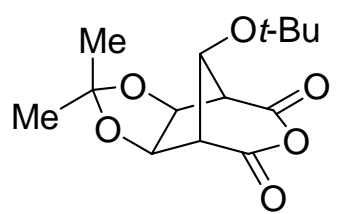

58

meso-glutaric anhydride 58. A round bottom flask was charged with $161 \mathrm{mg}(0.533$ mmol) of diacid $\mathbf{S 1 0}^{8}$ suspended in $5 \mathrm{~mL}$ of $\mathrm{CH}_{2} \mathrm{Cl}_{2}$ and cooled to $0{ }^{\circ} \mathrm{C}$ before the addition of $0.31 \mathrm{~mL}(2.2 \mathrm{mmol})$ of trifluoroacetic anhydride via syringe. The reaction was stirred for $35 \mathrm{~min}$. at $0{ }^{\circ} \mathrm{C}$ before being concentrated. The crude anhydride was dissolved in $\mathrm{CHCl}_{3}(25 \mathrm{~mL})$ and washed with $5 \%$ aq. $\mathrm{NaHCO}_{3}(1 \mathrm{X} 20 \mathrm{~mL})$. The organic layer was dried over $\mathrm{MgSO}_{4}$ and concentrated yielding $130 \mathrm{mg}$ (86 \%) of anhydride 58 as a white solid: $\mathrm{mp}=153-156{ }^{\circ} \mathrm{C}\left(\mathrm{CHCl}_{3}\right) ; \mathrm{R}_{\mathrm{f}}=0.55(1: 1 \mathrm{Hex} / \mathrm{EtOAc}) ;{ }^{1} \mathrm{H}$ NMR (400 MHz, CDCl 3 ) $\delta 4.69$ (s, 2H), 4.58 (t, 1H, J = 4.6 Hz), 3.34 (d, 2H, J = 4.3 Hz), 1.50 (s, 3H), 1.31 (s, 3H), 1.21 (s, 9H); $\left.{ }^{13} \mathrm{C} \mathrm{NMR} \mathrm{(100} \mathrm{MHz,} \mathrm{CDCl}_{3}\right) \delta 164.9,112.5$, 77.5, 76.0, 70.2, 53.5, 27.9, 25.6, 23.7; IR ( $\mathrm{NaCl}$, dep from $\mathrm{CDCl}_{3}$ ) 2985, 2970, 1821, 1778, 1365, 1192, 1107, $995 \mathrm{~cm}^{-1}$; HRMS (FAB+) calcd for $\mathrm{C}_{14} \mathrm{H}_{21} \mathrm{O}_{6}$, 285.1338. Found 285.1329.

General procedure for the alkylative monofunctionalization of cyclic anhydrides: A flame-dried round bottom flask was charged with $\mathrm{Ni}(\mathrm{COD})_{2}(0.05$ to $0.1 \mathrm{eq})$ and 2,2'dipyridyl (bpy) or (2-diphenylphosphino)ethylpyridine (PYPHOS) (0.06 to $0.12 \mathrm{eq}$ ) in an inert atmosphere $\left(\mathrm{N}_{2}\right)$ glove box. Upon removal from the glove box, 1 to $2 \mathrm{ml}$ THF was added via syringe and the solution was stirred at ambient temperature for 15 minutes. The solution was then cooled to $0{ }^{\circ} \mathrm{C}$ in an ice bath and 4-(trifluoromethyl)styrene or 4fluorostyrene ( 0.1 to $0.2 \mathrm{eq})$ followed by diethylzinc (1.0M solution in hexane or neat, 1.2-2.4 eq) were added via syringe. Anhydride (1 eq) in THF was added via cannula and the reaction was stirred for the time and temperature indicated. The reaction mixture was then diluted with $10 \mathrm{ml}$ of ether and quenched with $10 \mathrm{ml} 1 \mathrm{M} \mathrm{HCl}$ (aq.). The layers were separated and the aqueous layer extracted with ether (2 X $10 \mathrm{~mL})$. Organics were combined and extracted with $1 \mathrm{M} \mathrm{Na}_{2} \mathrm{CO}_{3}$ (aq.) ( $2 \mathrm{X} 5 \mathrm{~mL}$ ), the basic layers were combined and brought to $\mathrm{pH}=1-2$ with concentrated $\mathrm{HCl}$. The acidified aqueous layer was extracted with $\mathrm{Et}_{2} \mathrm{O}(3 \mathrm{X} 10 \mathrm{~mL})$ and the combined organic extracts were washed with brine, dried over $\mathrm{MgSO}_{4}$, filtered, and concentrated in vacuo. For reactions in which the product acids were not analytically pure or existed as a mixture of rotamers, the corresponding methyl ester was generated by treatment with $\mathrm{CH}_{2} \mathrm{~N}_{2}$ in $\mathrm{Et}_{2} \mathrm{O}$ or $\mathrm{TMSCHN}_{2}\left(2.0 \mathrm{M}\right.$ in $\left.\mathrm{Et}_{2} \mathrm{O}\right)$ in 1:1 $\mathrm{MeOH} / \mathrm{PhH}$ at $0{ }^{\circ} \mathrm{C}$.

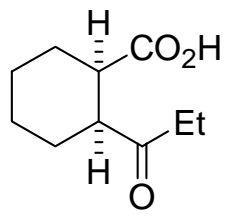

$\left(1 R^{*}, 2 S^{*}\right)$-2-propionyl-cyclohexanecarboxylic acid (2). According to the general procedure, $97.0 \mathrm{mg}(0.353 \mathrm{mmol})$ of $\mathrm{Ni}(\mathrm{COD})_{2}$ and $62.1 \mathrm{mg}$ $(0.398 \mathrm{mmol})$ of bpy in $4 \mathrm{~mL}$ of THF was treated with $50 \mu \mathrm{L}(0.34 \mathrm{mmol})$ of 4-(trifluoromethyl)styrene and $5.0 \mathrm{~mL}$ (1.0M solution in hexane, 5.0

\footnotetext{
${ }^{8}$ Ben Cheikh, A.; Craine, L. E.; Recher, S. G.; Zemlicka, J. J. Org. Chem. 1988, 53, 929-936.
} 
mmol) of $\mathrm{Et}_{2} \mathrm{Zn}$ at $0{ }^{\circ} \mathrm{C}$. $560 \mathrm{mg}$ (3.63 mmol) of anhydride 1 in $16 \mathrm{~mL}$ THF was added via cannula and the reaction was stirred for $3 \mathrm{~h}$ at $0{ }^{\circ} \mathrm{C}$. Upon work-up $625 \mathrm{mg}$ (93 \%) of desired acid 2 was isolated as a white solid: $\mathrm{mp}=71-73{ }^{\circ} \mathrm{C}\left(\mathrm{Et}_{2} \mathrm{O}\right) ;{ }^{1} \mathrm{H}$ NMR $(300 \mathrm{MHz}$, $\left.\mathrm{CDCl}_{3}\right) \delta 2.75-2.83(\mathrm{~m}, 2 \mathrm{H}), 2.52(\mathrm{dq}, 1 \mathrm{H}, J=18.0,7.3 \mathrm{~Hz}), 2.44$ (dq, $1 \mathrm{H}, J=18.0,7.3$ $\mathrm{Hz}), 1.95-2.10$ (m, 2H), 1.75-1.85 (m, 2H), 1.60 (m, 1H), 1.40 (m, 1H), 1.03 (dd, 3H, $J=$ 7.5, $7.5 \mathrm{~Hz}) ;{ }^{13} \mathrm{C}$ NMR $\left(75 \mathrm{MHz}, \mathrm{CDCl}_{3}\right) \mathrm{d}$ 212.1, 180.3, 49.1, 42.5, 33.3, 26.2, 26.0, 24.0, 23.6, 7.8; IR ( $\left.\mathrm{NaCl}, \mathrm{CDCl}_{3}\right)$ 3081, 2939, 2860, 1738, 1701, 1452, $1261 \mathrm{~cm}^{-1}$; HRMS (FAB+) calcd for $\mathrm{C}_{10} \mathrm{H}_{17} \mathrm{O}_{3}, 185.1178$. Found 185.1178.<smiles>CCC(=O)C1CCCC[C@H]1C(=O)O</smiles>

$\left(1 R^{*}, 2 R^{*}\right)$-2-propionyl-cyclohexanecarboxylic acid (7). According to the general procedure, $5.7 \mathrm{mg}(0.021 \mathrm{mmol})$ of $\mathrm{Ni}(\mathrm{COD})_{2}$ and $4.5 \mathrm{mg}$ $(0.029 \mathrm{mmol})$ of bpy in $1 \mathrm{~mL}$ of THF was treated with $5 \mu \mathrm{L}(0.042 \mathrm{mmol})$ of 4 -fluorostyrene and $45 \mu \mathrm{L}(0.44 \mathrm{mmol})$ of $\mathrm{Et}_{2} \mathrm{Zn}$ at $0{ }^{\circ} \mathrm{C} .56 \mathrm{mg}(0.36$ mmol) of anhydride 6 in $1 \mathrm{~mL}$ THF was added via cannula and the reaction was stirred for $4 \mathrm{~h}$ at $0{ }^{\circ} \mathrm{C}$. Upon work-up $58 \mathrm{mg}(87 \%)$ of desired acid 7 was isolated as a white solid: $\mathrm{mp}=109-111{ }^{\circ} \mathrm{C}\left(\mathrm{CH}_{2} \mathrm{Cl}_{2}\right) ;{ }^{1} \mathrm{H} \mathrm{NMR}\left(300 \mathrm{MHz}, \mathrm{CDCl}_{3}\right) \delta$ 2.62-2.71 (m, 2H), 2.55 (dq, 1H, $J=17.6,7.3 \mathrm{~Hz}$ ), 2.46 (dq, 1H, $J=17.6,7.1 \mathrm{~Hz}$ ), 2.13 (m, 1H), 1.95 (m, 1H), 1.77-1.80 (m, 2H), 1.08-1.35(m, 4H), 1.01 (dd, 3H, $J=7.3,7.3$ $\mathrm{Hz}) ;{ }^{13} \mathrm{C}$ NMR $\left(75 \mathrm{MHz}, \mathrm{CDCl}_{3}\right) \delta 213.6,181.5,50.9,44.0,34.4,28.9,28.7,25.5,25.3$, 7.7; IR ( $\mathrm{NaCl}, \mathrm{CDCl}_{3}$ ) 3034, 2860, 1699, 1450, 1265, 1209, $1136 \mathrm{~cm}^{-1}$; HRMS (FAB+) calcd for $\mathrm{C}_{10} \mathrm{H}_{17} \mathrm{O}_{3}, 185.1178$. Found 185.1175.<smiles>CCC(=O)C1CC=CCC1C(=O)O</smiles>

$\left(1 R^{*}, 6 S^{*}\right)-6$-propionyl-cyclohex-3-enecarboxylic acid (9). According to the general procedure, $39.0 \mathrm{mg}(0.142 \mathrm{mmol})$ of $\mathrm{Ni}(\mathrm{COD})_{2}$ and $26.5 \mathrm{mg}$ $(0.170 \mathrm{mmol})$ of bpy in $1 \mathrm{~mL}$ of THF was treated with $40 \mu \mathrm{L}(0.27 \mathrm{mmol})$ of 4-(trifluoromethyl)styrene and $2.0 \mathrm{~mL}$ (1.0M solution in hexane, 2.0 mmol) of $\mathrm{Et}_{2} \mathrm{Zn}$ at $0{ }^{\circ} \mathrm{C} .212 \mathrm{mg}(1.39 \mathrm{mmol})$ of anhydride 8 in $5 \mathrm{~mL}$ THF was added via cannula and the reaction was warmed to room temperature and stirred for $3 \mathrm{~h}$. Upon work-up $240 \mathrm{mg}$ (95\%) of desired acid 9 was isolated as a colorless oil: $\mathrm{R}_{\mathrm{f}}=$ 0.48 (1:1 EtOAc/hex); ${ }^{1} \mathrm{H}$ NMR (300 MHz, $\mathrm{CDCl}_{3}$ ) $\delta$ 5.63-5.71 (m, 2H), 3.03 (ddd, $1 \mathrm{H}, J$ = 6.4, 6.0, 3.3 Hz), 2.92 (ddd, $1 \mathrm{H}, J=6.6,6.2,3.3 \mathrm{~Hz}$ ), 2.29-2.64 (m, 7H), 1.03 (dd, 3H, $J=7.1,7.1 \mathrm{~Hz}) ;{ }^{13} \mathrm{C}$ NMR $\left(75 \mathrm{MHz}, \mathrm{CDCl}_{3}\right) \delta 211.2,179.9,125.7,124.4,46.2,39.3$, 33.0, 25.9, 25.5, 7.7; IR (NaCl, neat) 3030, 1705, 1437, $1250 \mathrm{~cm}^{-1}$; HRMS (FAB+) calcd for $\mathrm{C}_{10} \mathrm{H}_{15} \mathrm{O}_{3}, 183.1021$. Found 183.1021.<smiles>CCC(=O)C1CC(C)=C(C)CC1C(=O)O</smiles>

$\left(1 R^{*}, 6 S^{*}\right)$-3,4-Dimethyl-6-propionyl-cyclohex-3-enecarboxylic acid (11). According to the general procedure, $5.7 \mathrm{mg}(0.021 \mathrm{mmol})$ of $\mathrm{Ni}(\mathrm{COD})_{2}$ and $4.3 \mathrm{mg}(0.028 \mathrm{mmol})$ of bpy in $1 \mathrm{~mL}$ of THF was treated with $5 \mu \mathrm{L}(0.042 \mathrm{mmol})$ of 4-fluorostyrene and $50 \mu \mathrm{L}(0.49$ $\mathrm{mmol})$ of $\mathrm{Et}_{2} \mathrm{Zn}$ at $0{ }^{\circ} \mathrm{C}$. $64 \mathrm{mg}(0.36 \mathrm{mmol})$ of anhydride 10 in $1 \mathrm{~mL}$ THF was added via cannula and the reaction was stirred for $2 \mathrm{~h}$ at $0{ }^{\circ} \mathrm{C}$. Upon work-up $67 \mathrm{mg}$ (90\%) of desired acid 11 was isolated as a colorless oil: $\mathrm{R}_{\mathrm{f}}=0.45(1: 1$ Hex/EtOAc); ${ }^{1} \mathrm{H}$ NMR (400 MHz, $\left.\mathrm{CDCl}_{3}\right) \delta 2.99$ (ddd, $1 \mathrm{H}, J=6.4,6.43 .5 \mathrm{~Hz}$ ), 2.86 (ddd, 1H, $J=6.6,6.6,3.6 \mathrm{~Hz}$ ), 2.48 (q, 2H, $J=7.0 \mathrm{~Hz}$ ), 2.46-1.80 (m, 3H), 1.62 (s, 3H); 1.60 (s, 3H), 1.02 (t, 3H, $J=7.0 \mathrm{~Hz}) ;{ }^{13} \mathrm{C} \mathrm{NMR}\left(100 \mathrm{MHz}, \mathrm{CDCl}_{3}\right) \delta 211.6,180.1,124.7$, 123.3, 47.0, 40.0, 33.0, 31.9, 31.6, 19.0, 18.8, 7.6; IR ( $\mathrm{NaCl}$, neat) 3272, 2982, 2922, 
2859, 1701, 1248, $1112 \mathrm{~cm}^{-1}$; HRMS (FAB+) calcd for $\mathrm{C}_{12} \mathrm{H}_{19} \mathrm{O}_{3}, 211.1334$. Found 211.1341.<smiles>CCC(=O)[C@H]1Cc2ccccc2C[C@H]1C(C)=O</smiles>

(2R*, 3S*)-3-propionyl-1,2,3,4-tetrahydro-naphthalene-2carboxylic acid methyl ester (13). According to the general procedure, $5.1 \mathrm{mg}(0.019 \mathrm{mmol})$ of $\mathrm{Ni}(\mathrm{COD})_{2}$ and $3.4 \mathrm{mg}(0.022$ $\mathrm{mmol})$ of bpy in $1 \mathrm{~mL}$ of THF was treated with $5 \mu \mathrm{L}(0.042 \mathrm{mmol})$ of 4-fluorostyrene and $45 \mu \mathrm{L}(0.44 \mathrm{mmol})$ of $\mathrm{Et}_{2} \mathrm{Zn}$ at $0{ }^{\circ} \mathrm{C} .73 \mathrm{mg}$ $(0.36 \mathrm{mmol})$ of anhydride $12 \mathrm{in} 1 \mathrm{~mL}$ THF was added via cannula and the reaction was stirred for $4 \mathrm{~h}$ at $0{ }^{\circ} \mathrm{C}$. Upon work-up the crude acid was taken up in $2 \mathrm{~mL}$ of $\mathrm{MeOH} / \mathrm{PhH}$ (1:1) and $\mathrm{TMSCHN}_{2}\left(2.0 \mathrm{M}\right.$ in $\left.\mathrm{Et}_{2} \mathrm{O}\right)$ was added dropwise until the persistence of yellow color, several drops of AcOH were then added. The reaction was concentrated and purified by column chromotograhpy ( $9: 1 \mathrm{Hex} / \mathrm{EtOAc}$ ) providing $80 \mathrm{mg}$ (90\%) of methyl ester 13 as a colorless oil: $\mathrm{R}_{\mathrm{f}}=0.18$ (4:1 EtOAc/hex); ${ }^{1} \mathrm{H}$ NMR (400 MHz, $\left.\mathrm{CDCl}_{3}\right) \delta 7.12(\mathrm{~s}, 4 \mathrm{H}), 3.66(\mathrm{~s}, 3 \mathrm{H}), 3.32$ (dd, $\left.1 \mathrm{H}, \mathrm{J}=16.6,6.6 \mathrm{~Hz}\right), 3.26-3.07(\mathrm{~m}, 5 \mathrm{H})$, 2.62 (dq, 1H, J = 17.9, 7.2 Hz), 2.52 (dq, 1H, J = 17.9, 7.2 Hz), 1.05 (t, 3H, J = 7.2 Hz); ${ }^{13} \mathrm{C}$ NMR $\left(100 \mathrm{MHz}, \mathrm{CDCl}_{3}\right) \delta$ 210.9, 173.7, 134.2, 133.6, 129.1, 128.9, 126.2, 126.0, 51.9, 47.1, 40.3, 33.4, 29.7, 29.4, 7.6; IR (NaCl, neat) 3061, 3019, 2976, 2938, 1739, 1709, 1436, 1363, 1198, 1107, $1022 \mathrm{~cm}^{-1}$; HRMS (FAB+) calcd for $\mathrm{C}_{15} \mathrm{H}_{19} \mathrm{O}_{3}, 247.1334$. Found 247.1346.<smiles>CCC(=O)C1C(C)C=CC(C)C1C(C)=O</smiles>

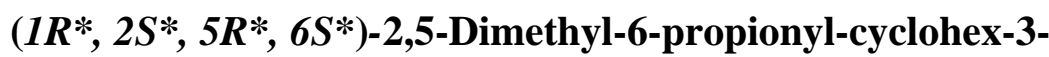
enecarboxylic acid methyl ester (15). According to the general procedure, $5.8 \mathrm{mg}(0.021 \mathrm{mmol})$ of $\mathrm{Ni}(\mathrm{COD})_{2}$ and $3.9 \mathrm{mg}(0.025 \mathrm{mmol})$ of bpy in $1 \mathrm{~mL}$ of THF was treated with $5 \mu \mathrm{L}(0.042 \mathrm{mmol})$ of $4-$ fluorostyrene and $50 \mu \mathrm{L}(0.49 \mathrm{mmol})$ of $\mathrm{Et}_{2} \mathrm{Zn}$ at $0{ }^{\circ} \mathrm{C} .67 \mathrm{mg}(0.37$ mmol) of anhydride 14 in $1 \mathrm{~mL}$ THF was added via cannula and the reaction was stirred for $3 \mathrm{~h}$ at $0{ }^{\circ} \mathrm{C}$. Upon work-up the crude acid was taken up in $2 \mathrm{~mL}$ of $\mathrm{MeOH} / \mathrm{PhH}(1: 1)$ and $\mathrm{TMSCHN}_{2}\left(2.0 \mathrm{M}\right.$ in $\left.\mathrm{Et}_{2} \mathrm{O}\right)$ was added dropwise until the persistence of yellow color, several drops of $\mathrm{AcOH}$ were then added. The reaction was concentrated and purified by column chromotograhpy (9 : $1 \mathrm{Hex} / \mathrm{EtOAc})$ providing $51 \mathrm{mg}$ (61\%) of methyl ester 15 as a colorless oil.: $\mathrm{R}_{\mathrm{f}}=0.36(4: 1 \mathrm{Hex} / \mathrm{EtOAc}) ;{ }^{1} \mathrm{H} \mathrm{NMR}\left(400 \mathrm{MHz}, \mathrm{CDCl}_{3}\right) \delta$ 5.61-5.57 (m, 1H), 5.51-5.47 (m, 1H), 3.66 (s, 3H), 3.14 (dd, 1H, $J=7.0,4.3 \mathrm{~Hz}), 2.92$ (dd, 1H, $J=$ 6.8, $4.3 \mathrm{~Hz}$ ), 2.72-2.67 (m 1H), 2.57-2.51 (m, 3H), 1.05 (d, 3H, J = 4.0 Hz), 1.03 (d, 3H, $J=7.0 \mathrm{~Hz}$ ), 1.02 (t, 3H, J = 7.0 Hz); ${ }^{13} \mathrm{C}$ NMR (100 MHz, $\left.\mathrm{CDCl}_{3}\right) \delta 211.9,173.7,130.5$, 129.4, 51.1, 51.0, 44.0, 36.4, 31.3, 30.7, 17.2, 17.0, 7.4; IR (NaCl, neat) 3016, 2972, 2880, 1730, 1715, 1456, 1436, 1373, $1159 \mathrm{~cm}^{-1}$; HRMS (FAB+) calcd for $\mathrm{C}_{13} \mathrm{H}_{21} \mathrm{O}_{3}$, 225.1491. Found 225.1489.

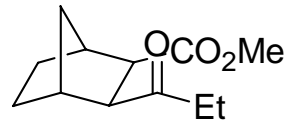

$\left(2 S^{*}, 3 R^{*}\right)$-3-propionyl-bicyclo[2.2.1]heptane-2-carboxylic methyl ester (17). According to the general procedure, $10.6 \mathrm{mg}(0.0385$ $\mathrm{mmol})$ of $\mathrm{Ni}(\mathrm{COD})_{2}$ and $6.9 \mathrm{mg}(0.044 \mathrm{mmol})$ of bpy in $1 \mathrm{~mL}$ of THF was treated with $10 \mu \mathrm{L}(0.068 \mathrm{mmol})$ of 4 -(trifluoromethyl)styrene and $0.5 \mathrm{~mL}(1.0 \mathrm{M}$ solution in hexane, $0.5 \mathrm{mmol})$ of $\mathrm{Et}_{2} \mathrm{Zn}$ at $0{ }^{\circ} \mathrm{C} .60 \mathrm{mg}(0.36 \mathrm{mmol})$ of anhydride 16 in 1 $\mathrm{mL}$ THF was added via cannula and the reaction was stirred $0{ }^{\circ} \mathrm{C}$ for $5 \mathrm{~h}$. Upon work-up the crude acid was taken up in $2 \mathrm{~mL}$ of $\mathrm{MeOH} / \mathrm{PhH}(1: 1)$ and $\mathrm{TMSCHN}_{2}\left(2.0 \mathrm{M}\right.$ in $\left.\mathrm{Et}_{2} \mathrm{O}\right)$ 
was added dropwise until the persistence of yellow color, several drops of AcOH were then added. Upon concentration, $60 \mathrm{mg}$ (79 \%) of pure methyl ester 17 were obtained: $\mathrm{R}_{\mathrm{f}}=0.38$ (4:1 Hex/EtOAc); ${ }^{1} \mathrm{H}$ NMR (400 MHz, $\left.\mathrm{CDCl}_{3}\right) \delta 3.57$ (s, 3H), 2.89 (d, 1H, J = $9.6 \mathrm{~Hz}$ ), 2.61-2.58 (m, 2H), 2.52-2.40 (m, 2H), 2.38 (s, 1H), 1.92 (d, 1H, J = $10.2 \mathrm{~Hz}$ ), 1.64-1.53 (m, 2H), 1.27-1.17 (m, 3H), 1.01 (t, 3H, $J=7.2 \mathrm{~Hz}) ;{ }^{13} \mathrm{C}$ NMR $(100 \mathrm{MHz}$, $\left.\mathrm{CDCl}_{3}\right) \delta 210.9,173.7,57.1,51.4,50.8,40.3,39.0,36.5,35.3,29.4,28.6,7.8 ; \mathrm{IR}(\mathrm{NaCl}$, $\mathrm{CDCl}_{3}$ ) 2953, 2875, 1742, 1714, 1456, 1435, 1346, 1238, 1198, $1174 \mathrm{~cm}^{-1}$; HRMS $\left(\mathrm{FAB}+\right.$ ) calcd for $\mathrm{C}_{12} \mathrm{H}_{19} \mathrm{O}_{3}, 211.1334$. Found 211.1343.

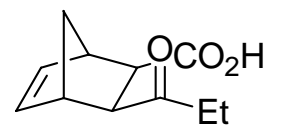

$\left(2 R^{*}, 3 S^{*}\right)$-3-propionyl-bicyclo[2.2.1]hept-5-ene-2-carboxylic acid (19). According to the general procedure, $9.8 \mathrm{mg}(0.036 \mathrm{mmol})$ of $\mathrm{Ni}(\mathrm{COD})_{2}$ and $6.8 \mathrm{mg}(0.044 \mathrm{mmol})$ of bpy in $1 \mathrm{~mL}$ of THF was treated with $10 \mu \mathrm{L}(0.068 \mathrm{mmol})$ of 4-(trifluoromethyl)styrene and $0.5 \mathrm{~mL}$ (1.0M solution in hexane, $0.5 \mathrm{mmol})$ of $\mathrm{Et}_{2} \mathrm{Zn}$ at $0{ }^{\circ} \mathrm{C} .63 \mathrm{mg}(0.39 \mathrm{mmol})$ of anhydride $18 \mathrm{in} 1 \mathrm{~mL}$ THF was added via cannula and the reaction was stirred $0{ }^{\circ} \mathrm{C}$ for $4 \mathrm{~h}$. Upon work-up $68 \mathrm{mg}$ (91\%) of desired acid 19 was isolated as an oil. Due to rotomers in NMR, the acid was converted to the corresponding methyl ester for characterization: $\mathrm{R}_{\mathrm{f}}=0.28$ (4:1 Hex/EtOAc); ${ }^{1} \mathrm{H}$ NMR (300 MHz, $\left.\mathrm{CDCl}_{3}\right) \delta$ 6.18-6.22 (m, 2H), 3.61 (s, 3H), 3.13 (m, 1H), 2.91 (m, 1H), 2.80 (dd, 1H, $J=9.5,1.6 \mathrm{~Hz}), 2.47-2.54$ (m, 3H), 2.02 (m, 1H), 1.43 (m, 1H), 1.04 (dd, 3H, $J=7.07 .0 \mathrm{~Hz}) ;{ }^{13} \mathrm{C}$ NMR (75 MHz, $\mathrm{CDCl}_{3}$ ) $\delta 211.1,173.9$, 138.0, 53.0, 51.7, 47.5, 45.9, 45.1, 45.0, 37.2, 7.9; IR ( $\left.\mathrm{NaCl}, \mathrm{CDCl}_{3}\right)$ 2977, 1739, 1713, $1240 \mathrm{~cm}^{-1}$; HRMS (FAB+) calcd for $\mathrm{C}_{12} \mathrm{H}_{17} \mathrm{O}_{3}, 209.1178$. Found 209.1179.

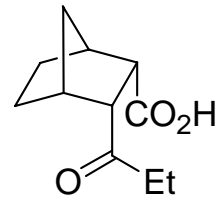

(2S*, 3R*)-3-propionyl-bicyclo[2.2.1] heptane-2-carboxylic acid (21). According to the general procedure, $10.3 \mathrm{mg}(0.0374 \mathrm{mmol})$ of $\mathrm{Ni}(\mathrm{COD})_{2}$ and $6.3 \mathrm{mg}(0.040 \mathrm{mmol})$ of bpy in $1 \mathrm{~mL}$ of THF was treated with $10 \mu \mathrm{L}$ $(0.068 \mathrm{mmol})$ of 4 -(trifluoromethyl)styrene and $0.5 \mathrm{~mL}(1.0 \mathrm{M}$ solution in hexane, $0.5 \mathrm{mmol})$ of $\mathrm{Et}_{2} \mathrm{Zn}$ at $0{ }^{\circ} \mathrm{C} .60 \mathrm{mg}(0.36 \mathrm{mmol})$ of anhydride $20 \mathrm{in} 1 \mathrm{~mL}$ THF was added via cannula and the reaction was stirred $0{ }^{\circ} \mathrm{C}$ for $3 \mathrm{~h}$. Upon work-up $62 \mathrm{mg}$ (88\%) of desired acid 21 was isolated as a white solid: $\mathrm{mp}=96-97{ }^{\circ} \mathrm{C}\left(\mathrm{Et}_{2} \mathrm{O}\right) ;{ }^{1} \mathrm{H} \mathrm{NMR}$

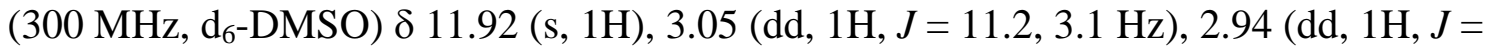
11.7, 3.7 Hz), 2.40-2.44 (m, 2H), 2.31 (dq, 1H, $J=17.2,7.5 \mathrm{~Hz}), 2.25$ (dq, $1 \mathrm{H}, J=17.0$, $7.3 \mathrm{~Hz}$ ), 1.23-1.62 (m, 6H), 0.89 (dd, 3H, $J=7.2,7.2 \mathrm{~Hz}) ;{ }^{13} \mathrm{C}$ NMR $\left(75 \mathrm{MHz}, \mathrm{d}_{6}-\right.$ DMSO) $\delta$ 209.6, 178.5, 53.6, 46.9, 40.8, 40.0, 39.9, 35.8, 24.6, 23.3, 7.7; IR (NaCl, $\mathrm{CDCl}_{3}$ ) 3095, 1734, 1709, $1205 \mathrm{~cm}^{-1}$; HRMS (FAB+) calcd for $\mathrm{C}_{11} \mathrm{H}_{17} \mathrm{O}_{3}, 197.1178$. Found 197.1179.

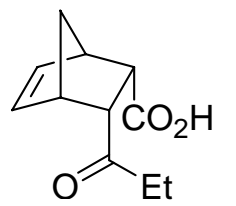

(2S*, 3R*)-3-propionyl-bicyclo[2.2.1]hept-5-ene-2-carboxylic acid (23). According to the general procedure, $10.0 \mathrm{mg}(0.0364 \mathrm{mmol})$ of $\mathrm{Ni}(\mathrm{COD})_{2}$ and $6.6 \mathrm{mg}(0.042 \mathrm{mmol})$ of bpy in $1 \mathrm{~mL}$ of THF was treated with $10 \mu \mathrm{L}$ $(0.068 \mathrm{mmol})$ of 4 -(trifluoromethyl)styrene and $0.5 \mathrm{~mL}(1.0 \mathrm{M}$ solution in hexane, $0.5 \mathrm{mmol})$ of $\mathrm{Et}_{2} \mathrm{Zn}$ at $0{ }^{\circ} \mathrm{C}$. $60 \mathrm{mg}(0.37 \mathrm{mmol})$ of anhydride $22 \mathrm{in} 1 \mathrm{~mL}$ THF was added via cannula and the reaction was stirred $0{ }^{\circ} \mathrm{C}$ for $4 \mathrm{~h}$. Upon work-up $68 \mathrm{mg}$ (96\%) of desired acid 23 was isolated as an oil. Due to rotomers in NMR, the acid was converted to the corresponding methyl ester for characterization: $\mathrm{R}_{\mathrm{f}}=0.20$ (4:1 Hex/EtOAc); ${ }^{1} \mathrm{H}$ NMR (300 MHz, $\mathrm{CDCl}_{3}$ ) $\delta 6.31$ (dd, $1 \mathrm{H}, J=5.5,3.3 \mathrm{~Hz}$ ), 6.07 (dd, 1H, 
$J=5.8,3.3 \mathrm{~Hz}$ ), 3.58 (s, 3H), 3.46 (dd, $1 \mathrm{H}, J=9.3,3.4 \mathrm{~Hz}$ ), 3.19 (dd, $1 \mathrm{H}, J=9.3,3.7$ $\mathrm{Hz}$ ), 3.12-3.17 (m, 2H), 2.47 (dq, $1 \mathrm{H}, J=17.6,7.4 \mathrm{~Hz}), 2.38$ (dq, $1 \mathrm{H}, J=17.7,7.1 \mathrm{~Hz}$ ), 1.33 (m, 1H), 1.00 (dd, 3H, $J=7.1,7.1 \mathrm{~Hz}$ ); ${ }^{13} \mathrm{C} \mathrm{NMR}\left(75 \mathrm{MHz}, \mathrm{CDCl}_{3}\right) \delta$ 208.9, 173.3, 135.5, 133.5, 55.1, 51.5, 48.6, 48.2, 46.8, 46.2, 36.2, 7.9; IR (NaCl, neat) 2978, 1738, 1715, 1435, $1338 \mathrm{~cm}^{-1}$; HRMS (FAB+) calcd for $\mathrm{C}_{12} \mathrm{H}_{17} \mathrm{O}_{3}, 209.1178$. Found 209.1174.

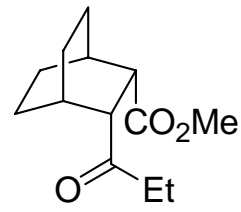

(2R*, 3S*)-3-Propionyl-bicyclo[2.2.2]oct-5-ene-2-carboxylic acid methyl ester (25). According to the general procedure, $5.1 \mathrm{mg}(0.019$ $\mathrm{mmol})$ of $\mathrm{Ni}(\mathrm{COD})_{2}$ and $3.8 \mathrm{mg}(0.024 \mathrm{mmol})$ of bpy in $1 \mathrm{~mL}$ of THF was treated with $5 \mu \mathrm{L}(0.042 \mathrm{mmol})$ of 4 -fluorostyrene and $45 \mu \mathrm{L}(0.44$ $\mathrm{mmol})$ of $\mathrm{Et}_{2} \mathrm{Zn}$ at $0{ }^{\circ} \mathrm{C}$. $65 \mathrm{mg}(0.36 \mathrm{mmol})$ of anhydride $24 \mathrm{in} 1 \mathrm{~mL}$ THF was added via cannula and the reaction was stirred $0{ }^{\circ} \mathrm{C}$ for $4 \mathrm{~h}$. Upon work-up $69 \mathrm{mg}$ (91 \%) of desired acid 25 was isolated as an oil. Due to rotomers in NMR, the acid was converted to the corresponding methyl ester for characterization: $R_{\mathrm{f}}=0.27$ (4:1 Hex/EtOAc); ${ }^{1} \mathrm{H}$ NMR (400 MHz, $\mathrm{CDCl}_{3}$ ) $\delta 3.60$ (s, 3H), 3.15 (dd, 1H, $J=10.7,2.1 \mathrm{~Hz}$ ), 2.68 (d, $1 \mathrm{H}, J=7.7 \mathrm{~Hz}$ ), 2.50-2.31 (m, 2H), 2.09-2.07 (m, 1H), 1.98 (s, 1H), 1.93-1.88 (m, 1H), 1.72-1.56 (m, 4H), 1.49-1.29 (m, 2H), 1.04 (t, 3H, $J=7.2 \mathrm{~Hz}) ;{ }^{13} \mathrm{C}$ NMR (100 $\left.\mathrm{MHz}, \mathrm{CDCl}_{3}\right) \delta 211.3,174.5,51.7,51.2$, 43.4, 34.7, 27.3, 26.2, 25.8, 21.3, 21.1, 7.9; IR $\left(\mathrm{NaCl}, \mathrm{CDCl}_{3}\right)$ 2944, 2869, 1735, 1717, 1458, 1434, 1356, $1192 \mathrm{~cm}^{-1}$; HRMS (FAB+) calcd for $\mathrm{C}_{13} \mathrm{H}_{21} \mathrm{O}_{3}, 225.1491$. Found 225.1482.

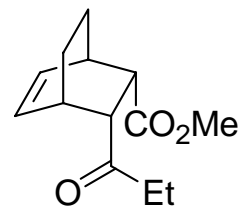

(2R*, 3S*)-3-Propionyl-bicyclo[2.2.2]oct-5-ene-2-carboxylic acid methyl ester (27). According to the general procedure, $5.0 \mathrm{mg}(0.018$ $\mathrm{mmol})$ of $\mathrm{Ni}(\mathrm{COD})_{2}$ and $3.4 \mathrm{mg}(0.022 \mathrm{mmol})$ of bpy in $1 \mathrm{~mL}$ of THF was treated with $5 \mu \mathrm{L}(0.042 \mathrm{mmol})$ of 4 -fluorostyrene and $45 \mu \mathrm{L}(0.44$ $\mathrm{mmol})$ of $\mathrm{Et}_{2} \mathrm{Zn}$ at $0{ }^{\circ} \mathrm{C}$. $65 \mathrm{mg}(0.36 \mathrm{mmol})$ of anhydride 26 in $1 \mathrm{~mL}$ THF was added via cannula and the reaction was stirred $0{ }^{\circ} \mathrm{C}$ for $4 \mathrm{~h}$. Upon work-up $64 \mathrm{mg}$ (84\%) of desired acid 27 was isolated as an oil. Due to rotomers in NMR, the acid was converted to the corresponding methyl ester for characterization: $\mathrm{R}_{\mathrm{f}}=0.27$ ( $4: 1$ Hex/EtOAc); ${ }^{1} \mathrm{H}$ NMR (400 MHz, $\left.\mathrm{CDCl}_{3}\right) \delta 6.37$ (t, $\left.1 \mathrm{H}, J=7.2 \mathrm{~Hz}\right), 6.16$ (t, $1 \mathrm{H}, J=7.2$ $\mathrm{Hz}$ ), 3.55 (s, 3H), 3.18 (dd, 1H, $J=10.8,1.6 \mathrm{~Hz}), 2.94-2.91$ (m, 2H), 2.81-2.79 (m, 1H), 2.49-2.33 (m, 2H), 1.60-1.49 (m, 2H), 1.37-1.25 (m, 2H), 1.00 (t, 3H, $J=7.2 \mathrm{~Hz}) ;{ }^{13} \mathrm{C}$ NMR $\left(100 \mathrm{MHz}, \mathrm{CDCl}_{3}\right) \delta 210.0,173.8,133.2,131.4,54.2,51.4,47.8,35.7,32.6,32.1$, 25.0, 24.5, 7.9; IR (NaCl, $\left.\mathrm{CDCl}_{3}\right)$ 30.52, 2945, 2870, 1740, 1718, 1460, 1434, 1197, 1166 $\mathrm{cm}^{-1}$; HRMS (FAB+) calcd for $\mathrm{C}_{13} \mathrm{H}_{19} \mathrm{O}_{3}, 223.1334$. Found 223.1331.

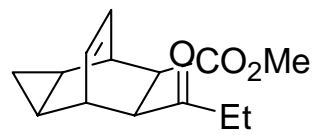

Tricyclic methyl ester 29. According to the general procedure, 11.4 $\mathrm{mg}(0.0414 \mathrm{mmol})$ of $\mathrm{Ni}(\mathrm{COD})_{2}$ and $6.8 \mathrm{mg}(0.044 \mathrm{mmol})$ of bpy in $1 \mathrm{~mL}$ of THF was treated with $10 \mu \mathrm{L}(0.084 \mathrm{mmol})$ of 4 -

fluorostyrene and $50 \mu \mathrm{L}$ of $\mathrm{Et}_{2} \mathrm{Zn}(0.49 \mathrm{mmol})$ at $0{ }^{\circ} \mathrm{C}$. $75 \mathrm{mg}(0.36 \mathrm{mmol})$ of anhydride 28 in $1.0 \mathrm{~mL}$ THF was added via cannula and the reaction was stirred for $18 \mathrm{~h}$ at $0{ }^{\circ} \mathrm{C}$. Upon work-up crude acid was taken up in $2 \mathrm{~mL}$ of $\mathrm{MeOH} / \mathrm{PhH}$ (1:1) and $\mathrm{TMSCHN}_{2}$ (2.0 $\mathrm{M}$ in $\mathrm{Et}_{2} \mathrm{O}$ ) was added dropwise until the persistence of yellow color, several drops of $\mathrm{AcOH}$ were then added. The reaction was concentrated and purified by column chromotograhpy (9 : 1 Hex/EtOAc) providing $66 \mathrm{mg}$ (68 \%) of methyl ester 29 as a 
colorless solid: $\mathrm{mp}=74-76{ }^{\circ} \mathrm{C} ; \mathrm{R}_{\mathrm{f}}=0 . .19$ (4 : $\left.1 \mathrm{Hex} / \mathrm{EtOAc}\right) ;{ }^{1} \mathrm{H}$ NMR $(400 \mathrm{MHz}$, $\left.\mathrm{CDCl}_{3}\right) \delta 5.93(\mathrm{t}, 1 \mathrm{H}, J=7.2 \mathrm{~Hz}), 5.74(\mathrm{t}, 1 \mathrm{H}, J=7.2 \mathrm{~Hz}), 3.56(\mathrm{~s}, 3 \mathrm{H}), 3.26$ (dd, $1 \mathrm{H}, J=$ 10.2, $1.9 \mathrm{~Hz}$ ), 3.18-3.16 (m, 1H), 3.05-3.03 (m, $1 \mathrm{H}), 3.02$ (dd, $1 \mathrm{H}, J=10.2,2.0 \mathrm{~Hz}$ ), 2.52-2.36 (m, 2H), 1.01 (t, 3H, $J=7.2 \mathrm{~Hz}), 0.98-0.92(\mathrm{~m}, 2 \mathrm{H}), 0.20-0.09(\mathrm{~m}, 2 \mathrm{H}) ;{ }^{13} \mathrm{C}$ NMR $\left(100 \mathrm{MHz}, \mathrm{CDCl}_{3}\right) \delta 210.4,174.1,128.5,127.0,55.2,51.7,48.9,36.4,34.6,34.1$, 10.2, 9.7, 8.1, 3.1; IR (NaCl, dep. $\mathrm{CHCl}_{3}$ ) 3059, 3014, 2978, 2951, 1734, 1711, 1430, 1372, 1196, 1047, $949 \mathrm{~cm}^{-1}$; HRMS (FAB+) calcd for $\mathrm{C}_{14} \mathrm{H}_{19} \mathrm{O}_{3}, 235.1334$. Found 235.1335 .

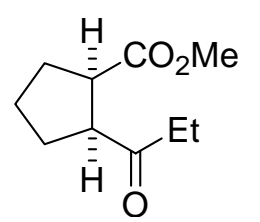

$\left(1 R^{*}, 2 S^{*}\right)$-2-Propionyl-cyclopentanecarboxylic acid methyl ester (31). According to the general procedure, $5.6 \mathrm{mg}(0.020 \mathrm{mmol})$ of $\mathrm{Ni}(\mathrm{COD})_{2}$ and $4.0 \mathrm{mg}(0.026 \mathrm{mmol})$ of bpy in $1 \mathrm{~mL}$ of THF was treated with $5 \mu \mathrm{L}(0.042 \mathrm{mmol})$ of 4 -fluorostyrene and $50 \mu \mathrm{L}$ of $\mathrm{Et}_{2} \mathrm{Zn}(0.49$ $\mathrm{mmol})$ at $0{ }^{\circ} \mathrm{C}$. $50 \mathrm{mg}(0.36 \mathrm{mmol})$ of anhydride 30 in $1 \mathrm{~mL}$ THF was added via cannula and the reaction was stirred for $3 \mathrm{~h}$ at $0{ }^{\circ} \mathrm{C}$. Upon work-up the crude acid was taken up in $2 \mathrm{~mL}$ of $\mathrm{MeOH} / \mathrm{PhH}(1: 1)$ and $\mathrm{TMSCHN}_{2}\left(2.0 \mathrm{M}\right.$ in $\left.\mathrm{Et}_{2} \mathrm{O}\right)$ was added dropwise until the persistence of yellow color, several drops of AcOH were then added. The reaction was concentrated and purified by column chromotograhpy (9:1 Hex/EtOAc) providing $47 \mathrm{mg}$ (71 \%) of methyl ester 31 as a colorless oil: $\mathrm{R}_{\mathrm{f}}=0.27(4: 1$ Hex/EtOAc); ${ }^{1} \mathrm{H}$ NMR (400 MHz, $\mathrm{CDCl}_{3}$ ) $\delta 3.60$ (s, 3H), 3.15 (q, 1H, J = $7.9 \mathrm{~Hz}$ ), 2.97 (q, $1 \mathrm{H}, J=7.9 \mathrm{~Hz}), 2.47$ (q, 1H, $J=7.1 \mathrm{~Hz}), 2.08-1.76$ (m, 5H), 1.67-1.56 (m, 1H), 1.01 $(\mathrm{t}, 3 \mathrm{H}, J=7.1 \mathrm{~Hz}) ;{ }^{13} \mathrm{C}$ NMR $\left(100 \mathrm{MHz}, \mathrm{CDCl}_{3}\right) \delta 212.0,174.7,53.4,51.5,46.8,35.3$, 28.4, 28.3, 23.9, 7.6; IR (NaCl, neat) 2966, 2952, 2876, 1734, 1710, 1456, 1436, 1363, $1201 \mathrm{~cm}^{-1}$; HRMS (FAB+) calcd for $\mathrm{C}_{10} \mathrm{H}_{17} \mathrm{O}_{3}, 185.1178$. Found 185.1179.<smiles>CCC(=O)[C@H]1CC[C@H]1C(=O)O</smiles>

$\left(1 R^{*}, 2 S^{*}\right)$-2-propinoyl-cyclobutanecarboxylic acid (33). According to the general procedure, $11.4 \mathrm{mg}(0.0414 \mathrm{mmol})$ of $\mathrm{Ni}(\mathrm{COD})_{2}$ and $12.9 \mathrm{mg}$ $(0.0443 \mathrm{mmol})$ of PYPHOS in $1 \mathrm{~mL}$ of THF was treated with $10 \mu \mathrm{L}(0.068$ $\mathrm{mmol})$ of 4-(trifluoromethyl)styrene and $0.5 \mathrm{~mL}(1.0 \mathrm{M}$ solution in hexanes, $0.5 \mathrm{mmol}) \mathrm{Et}_{2} \mathrm{Zn}$ at $0^{\circ} \mathrm{C} .46 \mathrm{mg}(0.37 \mathrm{mmol})$ of anhydride $32 \mathrm{in} 1 \mathrm{~mL} \mathrm{THF}$ was added via cannula and the reaction was stirred $0{ }^{\circ} \mathrm{C}$ for $4 \mathrm{~h}$. Upon work-up $35 \mathrm{mg}$ (61 \%) of desired acid 33 was isolated as an oil: $\mathrm{R}_{\mathrm{f}}=0.28$ (1:1 Hex/EtOAc); ${ }^{1} \mathrm{H}$ NMR (300 MHz, $\left.\mathrm{CDCl}_{3}\right) \delta$ 3.32-3.57 (m, 2H), 2.07-2.49 (m, 6H), 1.03 (dd, 3H, J = 7.3 7.3 Hz); ${ }^{13} \mathrm{C}$ NMR $\left(75 \mathrm{MHz}, \mathrm{CDCl}_{3}\right) \delta 210.5,179.7,47.0,40.7,34.3,21.9,21.8,7.9$; IR (NaCl, neat) 3073, 2741, 1699, $1414 \mathrm{~cm}^{-1}$; HRMS (FAB+) calcd for $\mathrm{C}_{8} \mathrm{H}_{13} \mathrm{O}_{3}, 157.0865$. Found 157.0864 .<smiles>CCC(=O)C(OC(C)=O)C(C(=O)O)C(=O)O</smiles>

(2S*, 3R*)-2,3-diacetoxy-4-oxo-hexanoic acid (35). According to the general procedure, $5.2 \mathrm{mg}(0.019 \mathrm{mmol})$ of $\mathrm{Ni}(\mathrm{COD})_{2}$ and $3.5 \mathrm{mg}$ $(0.022 \mathrm{mmol})$ of bpy in $1 \mathrm{~mL}$ of THF was treated with $5 \mu \mathrm{L}(0.042$ mmol) of 4-fluorostyrene and $50 \mu \mathrm{L}(0.49 \mathrm{mmol})$ of $\mathrm{Et}_{2} \mathrm{Zn}$ at $0{ }^{\circ} \mathrm{C} .77$ $\mathrm{mg}(0.35 \mathrm{mmol})$ of anhydride $34 \mathrm{in} 1 \mathrm{~mL}$ THF was added via cannula and the reaction was stirred $0{ }^{\circ} \mathrm{C}$ for $16 \mathrm{~h}$. Upon work-up $65 \mathrm{mg}$ (74\%) of desired acid 35 was isolated as an oil: $\mathrm{R}_{\mathrm{f}}=0.23\left(95: 5 \mathrm{CH}_{2} \mathrm{Cl}_{2} / \mathrm{MeOH}\right) ;{ }^{1} \mathrm{H} \mathrm{NMR}\left(400 \mathrm{MHz}, \mathrm{CDCl}_{3}\right) \delta 5.71(\mathrm{~d}, 1 \mathrm{H}, \mathrm{J}=$ $2.6 \mathrm{~Hz}$ ), 5.63 (d, 1H, J = 2.6 Hz), 2.62 (dq, 1H, J = 19.1, 7.2 Hz), 2.43 (dq, 1H, J = 19.0, $7.2 \mathrm{~Hz}$ ), 2.21 (s, 3H), 2.15 (s, 3H), 1.06 (t, 3H, J = 7.2 Hz); ${ }^{13} \mathrm{C}$ NMR (100 MHz, $\left.\mathrm{CDCl}_{3}\right)$ 
$\delta$ 204.2, 170.9, 169.8, 169.6, 76.7, 70.8, 32.5, 20.7, 20.5, 6.9; IR (NaCl, neat) 3214, 2982, 2945, 1749, 1375, 1221, 1106, $1049 \mathrm{~cm}^{-1}$; HRMS (FAB+) calcd for $\mathrm{C}_{10} \mathrm{H}_{15} \mathrm{O}_{7}, 247.0818$. Found 247.0827.<smiles>CCC(=O)C(OC(C)=O)C(OC(C)=O)C(=O)O</smiles>

$\left(2 R^{*}, 3 R^{*}\right)$-2,3-diacetoxy-4-oxo-hexanoic acid (37). According to the general procedure, $10.9 \mathrm{mg}(0.0396 \mathrm{mmol})$ of $\mathrm{Ni}(\mathrm{COD})_{2}$ and 6.4 $\mathrm{mg}(0.041 \mathrm{mmol})$ of bpy in $1 \mathrm{~mL}$ of THF was treated with $10 \mu \mathrm{L}$ $(0.068 \mathrm{mmol})$ of 4 -(trifluoromethyl)styrene and $0.5 \mathrm{~mL}$ (1.0M solution in hexane, $0.5 \mathrm{mmol})$ of $\mathrm{Et}_{2} \mathrm{Zn}$ at $0{ }^{\circ} \mathrm{C} .79 \mathrm{mg}(0.36 \mathrm{mmol})$ of anhydride 36 in $1 \mathrm{~mL}$ THF was added via cannula and the reaction was stirred $0{ }^{\circ} \mathrm{C}$ for $5 \mathrm{~h}$. Upon work-up $80 \mathrm{mg}$ (88 \%) of desired acid 37 was isolated as an oil: $\mathrm{R}_{\mathrm{f}}=0.61\left(4: 1 \mathrm{CH}_{2} \mathrm{Cl}_{2} / \mathrm{MeOH}\right) ;{ }^{1} \mathrm{H} \mathrm{NMR}$ $\left(300 \mathrm{MHz}, \mathrm{CDCl}_{3}\right) \delta 5.70(\mathrm{~d}, 1 \mathrm{H}, J=2.5 \mathrm{~Hz}), 5.64$ (d, $\left.1 \mathrm{H}, J=2.6 \mathrm{~Hz}\right), 2.58$ (dq, 1H, $J=$ 18.6, 7.3 Hz) , 2.43 (dq, 1H, $J=18.6,7.3 \mathrm{~Hz}$ ), 2.20 (s, 3H), 2.13 (s, 3H), 1.06 (dd, 3H, $J$ = 7.1, $7.1 \mathrm{~Hz}) ;{ }^{13} \mathrm{C} \mathrm{NMR}\left(75 \mathrm{MHz}, \mathrm{CDCl}_{3}\right) \delta$ 203.6, 170.9, 170.0, 169.6, 76.3, 70.2, 32.3, 20.5, 20.3, 7.7; IR (NaCl, neat) 3196, 2983, 1755, 1713, $1375 \mathrm{~cm}^{-1}$; HRMS (FAB+) calcd for $\mathrm{C}_{10} \mathrm{H}_{15} \mathrm{O}_{7}, 247.0818$. Found 247.0816.<smiles>CCC(=O)C(C)C(C)C(=O)O</smiles>

(2S*, 3R*)-2,3-dimethyl-4-oxo-hexanoic acid (39). According to the general procedure, $10.3 \mathrm{mg}(0.0374 \mathrm{mmol})$ of $\mathrm{Ni}(\mathrm{COD})_{2}$ and $6.0 \mathrm{mg}$ $(0.0384 \mathrm{mmol})$ of bpy in $1 \mathrm{~mL}$ of THF was treated with $10 \mu \mathrm{L}(0.068$ $\mathrm{mmol})$ of 4 -(trifluoromethyl)styrene and $0.5 \mathrm{~mL}(1.0 \mathrm{M}$ solution in hexane, $0.5 \mathrm{mmol})$ of $\mathrm{Et}_{2} \mathrm{Zn}$ at $0{ }^{\circ} \mathrm{C} .46 \mathrm{mg}(0.36 \mathrm{mmol})$ of anhydride $38 \mathrm{in} 1 \mathrm{~mL} \mathrm{THF}$ was added via cannula and the reaction was stirred $0{ }^{\circ} \mathrm{C}$ for $5 \mathrm{~h}$. Upon work-up $53 \mathrm{mg}$ (93\%) of desired acid 39 was isolated as an oil: $\mathrm{R}_{\mathrm{f}}=0.38$ (1:1 Hex/EtOAc); ${ }^{1} \mathrm{H}$ NMR $\left(300 \mathrm{MHz}, \mathrm{CDCl}_{3}\right.$ ) $\delta$ 2.74-2.85 (m, 2H), 2.57 (dq, $1 \mathrm{H}, J=18.0,7.2 \mathrm{~Hz}$ ) , 2.43 (dq, 1H, $J$ = 18.0, $7.2 \mathrm{~Hz}), 1.12-1.17(\mathrm{~m}, 6 \mathrm{H}), 1.05(\mathrm{dd}, 3 \mathrm{H}, J=7.37 .3 \mathrm{~Hz}) ;{ }^{13} \mathrm{C}$ NMR $(75 \mathrm{MHz}$, $\left.\mathrm{CDCl}_{3}\right) \delta 213.2$, 180.9, 48.2, 41.8, 35.3, 15.2, 15.0, 7.7; IR (NaCl, neat) 3093, 2941, 1713, $1381 \mathrm{~cm}^{-1}$; HRMS (FAB+) calcd for $\mathrm{C}_{8} \mathrm{H}_{15} \mathrm{O}_{3}, 159.1021$. Found 159.1026.<smiles>CCOC(=O)CCCC[C@H](CCCC(=O)OCC)C(=O)CC</smiles>

$\left(5 R^{*}, 6 S^{*}\right)$-5-carboxy-6-propionyl-decanedioic acid diethyl ester (41). According to the general procedure, $5.4 \mathrm{mg}(0.020$ $\mathrm{mmol})$ of $\mathrm{Ni}(\mathrm{COD})_{2}$ and $4.3 \mathrm{mg}(0.028 \mathrm{mmol})$ of bpy in $1 \mathrm{~mL}$ of THF was treated with $5 \mu \mathrm{L}(0.042 \mathrm{mmol})$ of 4-fluorostyrene and $50 \mu \mathrm{L}(0.49 \mathrm{mmol})$ of $\mathrm{Et}_{2} \mathrm{Zn}$ at $0{ }^{\circ} \mathrm{C} .116 \mathrm{mg}(0.353 \mathrm{mmol})$ of anhydride 40 in $1.0 \mathrm{~mL}$ THF was added via cannula and the reaction was stirred $0{ }^{\circ} \mathrm{C}$ for $4 \mathrm{~h}$. Upon work-up $95 \mathrm{mg}$ (75 \%) of desired acid 41 was isolated as an oil: $\mathrm{R}_{\mathrm{f}}=0.38$ (1:1 Hex/EtOAc); ${ }^{1} \mathrm{H}$ NMR (400 MHz, $\left.\mathrm{CDCl}_{3}\right) \delta 4.08$ (q, 2H, $J=6.9 \mathrm{~Hz}$ ), 4.07 (q, 2H, $J$ $=7.0 \mathrm{~Hz}$ ), 2.81-2.77 (m, 1H), 2.67-2.62 (m, 1H), 2.47 (q, 2H, $J=7.2 \mathrm{~Hz}), 2.32-2.22(\mathrm{~m}$, 4H), 1.68-1.43 (m, 7H), 1.36-1.29 (m, 1H), 1.21 (t, 6H, J = 7.0 Hz), 1.02 (t, 3H, J = 7.2 $\mathrm{Hz}) ;{ }^{13} \mathrm{C}$ NMR $\left(100 \mathrm{MHz}, \mathrm{CDCl}_{3}\right) \delta 213.0,178.9,173.3,173.2,60.4,53.0,47.2,37.3$, 34.0, 33.7, 29.8, 29.7, 22.8, 22.3, 14.1, 7.3; IR ( $\mathrm{NaCl}$, neat) 3208, 2980, 2941, 1735, 1701, 1459, 1375, 1185, $1030 \mathrm{~cm}^{-1}$; HRMS (FAB+) calcd for $\mathrm{C}_{18} \mathrm{H}_{31} \mathrm{O}_{7}, 359.2070$. Found 359.2070.<smiles>CCC(=O)CC(C)CC(=O)O</smiles>

3-methyl-5-oxo-heptanoic acid (43). According to the general procedure, $11.1 \mathrm{mg}(0.0404 \mathrm{mmol})$ of $\mathrm{Ni}(\mathrm{COD})_{2}$ and $14.0 \mathrm{mg}$ 
(0.0481 mmol) of PYPHOS in $1 \mathrm{~mL}$ of THF was treated with $10 \mu \mathrm{L}(0.0675 \mathrm{mmol})$ of 4 (trifluoromethyl)styrene and $0.5 \mathrm{~mL}(1.0 \mathrm{M}$ solution in hexane, $5.0 \mathrm{mmol})$ of $^{\mathrm{Et}} \mathrm{Zn}_{2} \mathrm{Zn} 0$ ${ }^{\circ} \mathrm{C}$. $49 \mathrm{mg}(0.38 \mathrm{mmol})$ of anhydride $42 \mathrm{in} 1 \mathrm{~mL}$ THF was added via cannula and the reaction was stirred for $10 \mathrm{~h}$ at ambient temperature. Upon work-up $49 \mathrm{mg}$ (81\%) of desired acid 43 was isolated as a colorless oil: ${ }^{1} \mathrm{H}$ NMR $\left(300 \mathrm{MHz}, \mathrm{CDCl}_{3}\right) \delta 11.70$ (br s, 1H), 2.54-2.20 (m, 7H), 1.02 (t, 3H, J = 7.3 Hz), 0.98 (d, 3H, J = 6.3 Hz); ${ }^{13} \mathrm{C}$ NMR (75 $\left.\mathrm{MHz}_{\mathrm{CDCl}}\right) \delta 210.4,178.6,48.4,40.6,36.4,26.2,20.0,7.8$.<smiles>CCC(=O)CC(CC(=O)O)c1ccccc1</smiles>

3-phenyl-5-oxo-heptanoic acid (45). According to the general procedure, $9.5 \mathrm{mg}(0.035 \mathrm{mmol})$ of $\mathrm{Ni}(\mathrm{COD})_{2}$ and $13.1 \mathrm{mg}(0.0450$ $\mathrm{mmol})$ of PYPHOS in $1 \mathrm{~mL}$ of THF was treated with $10 \mu \mathrm{L}(0.068$ mmol) of 4-fluorostyrene and $50 \mu \mathrm{L}$ of Et $2 \mathrm{Zn}(0.49 \mathrm{mmol})$ at $0{ }^{\circ} \mathrm{C} .69 \mathrm{mg}(0.36 \mathrm{mmol})$ of anhydride 44 in $1 \mathrm{~mL}$ THF was added via cannula and the reaction was stirred for $4 \mathrm{~h}$ at $0{ }^{\circ} \mathrm{C}$. Upon work-up $62 \mathrm{mg}$ (78 \%) of desired acid 45 was isolated as a white solid: $\mathrm{mp}=82-84{ }^{\circ} \mathrm{C}(\mathrm{EtOAc}) ; \mathrm{R}_{\mathrm{f}}=0.21$ (1:1 EtOAc/Hex); ${ }^{1} \mathrm{H}$ NMR $\left(400 \mathrm{MHz}, \mathrm{CDCl}_{3}\right) \delta 7.35-$ 7.31 (m, 2H), 7.26-7.24 (m, 3H), 3.72 (dddd, 1H, $J=7.2,7.2,7.2,7.2 \mathrm{~Hz}$ ), 2.84-2.82 (m, 2H), 2.77 (dd, $1 \mathrm{H}, J=16.0,7.0 \mathrm{~Hz}$ ), 2.68 (dd, $1 \mathrm{H}, J=16.0,7.7 \mathrm{~Hz}), 2.39$ (dq, $1 \mathrm{H}, J=$ 17.7, $7.3 \mathrm{~Hz}$ ), 2.31 (dq, $1 \mathrm{H}, J=17.9,7.3 \mathrm{~Hz}), 0.99$ (t, 3H, $J=7.3 \mathrm{~Hz}) ;{ }^{13} \mathrm{C}$ NMR (100 $\left.\mathrm{MHz} \mathrm{CDCl}_{3}\right) \delta 209.6,177.4,142.9,128.7,127.2,126.9,48.1,40.2$, 37.0, 36.5, 7.5; IR (NaCl, dep from $\mathrm{CHCl}_{3}$ ) 3032, 2982, 2943, 1713, 1416, 1269, 1115, $960 \mathrm{~cm}^{-1}$; HRMS (FAB+) calcd for $\mathrm{C}_{13} \mathrm{H}_{17} \mathrm{O}_{3}, 221.1178$. Found 221.1178.<smiles>CCC(=O)CC(CC(=O)O)OC(=O)CC</smiles>

3-benzyloxy-5-oxo-heptanoic acid (47). According to the general procedure, $5.0 \mathrm{mg}(0.018 \mathrm{mmol})$ of $\mathrm{Ni}(\mathrm{COD})_{2}$ and $6.1 \mathrm{mg}(0.021$ mmol) of PYPHOS in $1 \mathrm{~mL}$ of THF was treated with $5 \mu \mathrm{L}(0.042$ mmol) of 4-fluorostyrene and $45 \mu \mathrm{L}$ of $\mathrm{Et}_{2} \mathrm{Zn}(0.44 \mathrm{mmol})$ at $0{ }^{\circ} \mathrm{C} .80 \mathrm{mg}(0.36 \mathrm{mmol})$ of anhydride 46 in $1 \mathrm{~mL}$ THF was added via cannula and the reaction was stirred for $4 \mathrm{~h}$ at $0{ }^{\circ} \mathrm{C}$. Upon work-up $47 \mathrm{mg}$ (52\%) of desired acid 47 was isolated as a colorless oil: $\mathrm{R}_{\mathrm{f}}=0.21$ (1:1 Hex/EtOAc); ${ }^{1} \mathrm{H}$ NMR (400 MHz, $\left.\mathrm{CDCl}_{3}\right) \delta$ 7.31-7.24 (m, 5H), 4.58 (d, $1 \mathrm{H}, \mathrm{J}=11.1 \mathrm{~Hz}$ ), 4.51 (d, 1H, J = 11.1 Hz), 4.35 (dddd, 1H, J = 6.0, 6.0, 6.0, $6.0 \mathrm{~Hz}$ ), 2.82 (dd, 1H, J = 16.4, $6.8 \mathrm{~Hz}$ ), 2.67-2.62 (m, 3H), 2.41 (q, 2H, J = 7.2 Hz), 1.02 (t, 3H, J $=7.2 \mathrm{~Hz}) ;{ }^{13} \mathrm{C}$ NMR $\left(100 \mathrm{MHz}, \mathrm{CDCl}_{3}\right) \delta 209.6,176.7,138.0,128.6,128.1,128.0,72.5$, 72.2, 47.0, 39.4, 37.2, 7.7; IR (NaCl, neat) 3163, 3032, 2978, 2939, 1713, 1454, 1408, 1377, 1211, 1092, $1065 \mathrm{~cm}^{-1}$; HRMS (FAB+) calcd for $\mathrm{C}_{14} \mathrm{H}_{19} \mathrm{O}_{4}, 251.1283$. Found 251.1284 .<smiles>CCC(=O)CC(N)CC(=O)O</smiles>

5-oxo-3-(toluene-4-sulfonylamino)-heptanoic acid (49).

According to the general procedure, $5.0 \mathrm{mg}(0.018 \mathrm{mmol})$ of $\mathrm{Ni}(\mathrm{COD})_{2}$ and $6.1 \mathrm{mg}(0.021 \mathrm{mmol})$ of PYPHOS in $1 \mathrm{~mL}$ of THF was treated with $5 \mu \mathrm{L}(0.042 \mathrm{mmol})$ of 4 -fluorostyrene and $50 \mu \mathrm{L}$ of $\mathrm{Et}_{2} \mathrm{Zn}(0.49 \mathrm{mmol})$ at $0{ }^{\circ} \mathrm{C}$. $87 \mathrm{mg}$ ( $\left.0.36 \mathrm{mmol}\right)$ of anhydride $48 \mathrm{in} 1 \mathrm{~mL}$ THF was added via cannula and the reaction was stirred for $6 \mathrm{~h}$ at $0{ }^{\circ} \mathrm{C}$ then warmed to ambient temperature and stirred an additional $18 \mathrm{~h}$. Work-up afforded the crude acid that was purified by column chromatography (95:5 $\left.\mathrm{CH}_{2} \mathrm{Cl}_{2} / \mathrm{MeOH}\right)$ providing $55 \mathrm{mg}$ (57\%) of the desired acid 49 was isolated as a white solid: $\mathrm{mp}=138-140{ }^{\circ} \mathrm{C}\left(\mathrm{CHCl}_{3} / \mathrm{MeOH}\right) ; \mathrm{R}_{\mathrm{f}}=0.13(1: 1 \mathrm{EtOAc} / \mathrm{Hex})$; ${ }^{1} \mathrm{H}$ NMR (400 MHz, CD $\left.{ }_{3} \mathrm{OD}\right) \delta 7.72$ (d, 2H, J = 8.3 Hz), 7.36 (d, 2H, J = 8.1 Hz), 3.98 
(m, 1H), 2.67 (dd, 1H, $J=16.8,6.2 \mathrm{~Hz}$ ), 2.59 (dd, 1H, $J=16.8,6.4 \mathrm{~Hz}$ ), 2.42 (s, 3H), 2.41-2.40 (m, 2H), 2.33 (q, 2H, $J=7.3 \mathrm{~Hz}), 0.91$ (t, 3H, $J=7.3 \mathrm{~Hz}) ;{ }^{13} \mathrm{C}$ NMR $(100$ $\left.\mathrm{MHz}, \mathrm{CD}_{3} \mathrm{OD}\right) \delta 210.9,174.3,144.9,139.9,130.9,128.3,47.7,40.4,37.1,21.6,7.9$; IR $\left(\mathrm{NaCl}\right.$, dep. $\left.\mathrm{CHCl}_{3}\right)$ 3163, 3032, 2978, 2939, 1713, 1454, 1408, 1377, 1211, 1092, 1065 $\mathrm{cm}^{-1}$; HRMS (FAB+) calcd for $\mathrm{C}_{14} \mathrm{H}_{20} \mathrm{NO}_{5} \mathrm{~S}$, 314.1062. Found 314.1069.<smiles>CCC(=O)CC(C)(CC(=O)O)OC(=O)CC</smiles>

3-acetoxy-3-methyl-5-oxo-heptanoic acid (51). According to the general procedure, $5.0 \mathrm{mg}(0.018 \mathrm{mmol})$ of $\mathrm{Ni}(\mathrm{COD})_{2}$ and $6.1 \mathrm{mg}$ (0.021 mmol) of PYPHOS in $1 \mathrm{~mL}$ of THF was treated with $5 \mu \mathrm{L}$ $(0.042 \mathrm{mmol})$ of 4 -fluorostyrene and $50 \mu \mathrm{L}$ of $\mathrm{Et}_{2} \mathrm{Zn}(0.49 \mathrm{mmol})$ at $0{ }^{\circ} \mathrm{C} .34 \mathrm{mg}(0.18$ mmol) of anhydride 50 in $1 \mathrm{~mL}$ THF was added via cannula and the reaction was stirred for $4 \mathrm{~h}$ at $0{ }^{\circ} \mathrm{C}$. Work-up afforded the $29 \mathrm{mg}$ (75\%) of the desired acid 51 as a colorless oil: $\mathrm{R}_{\mathrm{f}}=0.26$ (1:1 EtOAc/Hex); ${ }^{1} \mathrm{H}$ NMR (400 MHz, $\left.\mathrm{CDCl}_{3}\right) \delta 3.25$ (d, $1 \mathrm{H}, J=16.8$ $\mathrm{Hz}), 3.18$ (d, 1H, $J=17.2 \mathrm{~Hz}$ ), 3.11 (s, 2H), 2.44 (q, 2H, $J=7.3 \mathrm{~Hz}$ ), 2.00 ( s, 3H), 1.64 (s, 3H), 1.04 (t, 3H, $J=7.3 \mathrm{~Hz}) ;{ }^{13} \mathrm{C}$ NMR $\left(100 \mathrm{MHz}, \mathrm{CDCl}_{3}\right) \delta 208.6,174.9,170.5$, 79.5, 48.6, 41.9, 37.4, 24.9, 22.2, 7.5; IR (NaCl, neat) 3243, 2979, 2941, 1734, 1718, 1372, $1251 \mathrm{~cm}^{-1}$; HRMS (FAB+) calcd for $\mathrm{C}_{10} \mathrm{H}_{17} \mathrm{O}_{5}, 217.1076$. Found 217.1069.<smiles>CCC(=O)C(C)CC(C)C(=O)O</smiles>

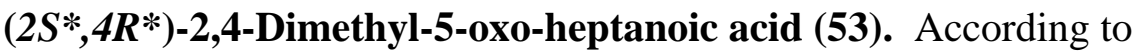
the general procedure, $9.8 \mathrm{mg}(0.036 \mathrm{mmol})$ of $\mathrm{Ni}(\mathrm{COD})_{2}$ and 13.5 $\mathrm{mg}(0.0463 \mathrm{mmol})$ of PYPHOS in $1 \mathrm{~mL}$ of THF was treated with 10 $\mu \mathrm{L}(0.084 \mathrm{mmol})$ of 4 -fluorostyrene and $50 \mu \mathrm{L}$ of $\mathrm{Et}_{2} \mathrm{Zn}(0.49$ $\mathrm{mmol})$ at $0{ }^{\circ} \mathrm{C} .52 \mathrm{mg}(0.37 \mathrm{mmol})$ of anhydride 52 in $0.4 \mathrm{~mL}$ THF was added via syringe and the reaction was stirred for $14 \mathrm{~h}$ at $0{ }^{\circ} \mathrm{C}$. Upon work-up $53 \mathrm{mg}$ (85\%) of desired acid 53 was isolated as a colorless oil: $\mathrm{R}_{\mathrm{f}}=0.21$ (1:1 EtOAc/Hex); ${ }^{1} \mathrm{H}$ NMR (300 $\mathrm{MHz} \mathrm{CDCl}_{3}$ ) $\delta 10.49$ (br s, 1H), 2.68-2.58 (m, 1H), 2.55-2.38 (m, 2H), 2.07 (ddd, 1H, $J$ = 13.9, 8.9, $6.2 \mathrm{~Hz}$ ), 1.27 (ddd, $1 \mathrm{H}, J=14.2,7.9,6.0 \mathrm{~Hz}$ ), 1.19 (d, 3H, $J=7.1 \mathrm{~Hz}$ ), 1.09 (d, 3H, $J=6.9 \mathrm{~Hz}), 1.03$ (dd, 3H, $J=7.1,7.1 \mathrm{~Hz}) ;{ }^{13} \mathrm{C}$ NMR $\left(75 \mathrm{MHz}, \mathrm{CDCl}_{3}\right) \delta 214.3$, 182.3, 43.8, 37.3, 36.2, 34.1, 17.7, 16.9, 7.8; IR (NaCl, neat) 3093, 2976, 2939, 1737, 1713, 1464, $1379 \mathrm{~cm}^{-1}$; HRMS (FAB+) calcd for $\mathrm{C}_{9} \mathrm{H}_{17} \mathrm{O}_{3}, 172.1099$. Found 172.1097.

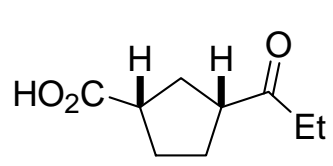

$\left(1 S^{*}, 3 R^{*}\right)$-3-Propionyl-cyclopentanecarboxylic acid (55).

According to the general procedure, $24.5 \mathrm{mg}(0.0891 \mathrm{mmol})$ of $\mathrm{Ni}(\mathrm{COD})_{2}$ and $28.1 \mathrm{mg}(0.0965 \mathrm{mmol})$ of PYPHOS in $4 \mathrm{~mL}$ of THF was treated with $20 \mu \mathrm{L}(0.17 \mathrm{mmol})$ of 4-fluorostyrene and $250 \mu \mathrm{L}$ of $\mathrm{Et}_{2} \mathrm{Zn}(2.44 \mathrm{mmol})$ at $0{ }^{\circ} \mathrm{C} .264 \mathrm{mg}(1.88 \mathrm{mmol})$ of anhydride $54 \mathrm{in} 2 \mathrm{~mL}$ THF was added via cannula and the reaction was stirred for $14 \mathrm{~h}$ at $0{ }^{\circ} \mathrm{C}$. Upon work-up $288 \mathrm{mg}$ (90\%) of the desired acid 55 was isolated as a colorless oil: $\mathrm{R}_{\mathrm{f}}=0.42$ (1:1 EtOAc/Hex); ${ }^{1} \mathrm{H}$ NMR (400 MHz, $\mathrm{CDCl}_{3}$ ) $\delta 2.94$ (dddd, 1H, J = 7.9, 7.9, 7.9, $7.9 \mathrm{~Hz}$ ), 2.85 (dddd, 1H, $\mathrm{J}=7.97 .97 .97 .9 \mathrm{~Hz}$ ), 2.48 (q, 2H, J = 7.2 Hz), 2.21-2.14 (m, 1H), 2.11-2.03 (m, 1H), 1.99-1.84 (m, 4H), 1.05 (t, 2H, J = 7.2 Hz); ${ }^{13} \mathrm{C} \mathrm{NMR} \mathrm{(100} \mathrm{MHz,} \mathrm{CDCl}_{3}$ ) $\delta$ 212.6, 181.1, 51.0, 43.8, 34.7, 32.1, 29.1, 28.4, 7.8; IR (NaCl, neat) 3095, 2973, 2943, 2879, 1734, 1709, 1452, 1414, 1377, $1240 \mathrm{~cm}^{-1}$; HRMS (FAB+) calcd for $\mathrm{C}_{9} \mathrm{H}_{15} \mathrm{O}_{3}, 171.1021$. Found 171.1027. 


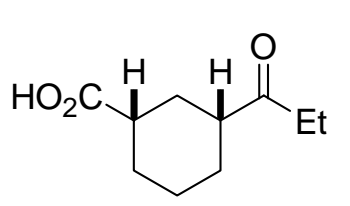

\section{$\left(1 S^{*}, 3 R^{*}\right)$-3-Propionyl-cyclohexanecarboxylic acid (57).}

According to the general procedure, $5.4 \mathrm{mg}(0.020 \mathrm{mmol})$ of

$\mathrm{Ni}(\mathrm{COD})_{2}$ and $7.0 \mathrm{mg}(0.024 \mathrm{mmol})$ of PYPHOS in $1 \mathrm{~mL}$ of THF was treated with $5.0 \mu \mathrm{L}(0.042 \mathrm{mmol})$ of 4 -fluorostyrene and $45 \mu \mathrm{L}$ of Et $2 \mathrm{Zn}(0.44 \mathrm{mmol})$ at $0{ }^{\circ} \mathrm{C} .55 \mathrm{mg}(0.36 \mathrm{mmol})$ of anhydride 56

in $1 \mathrm{~mL}$ THF was added via syringe and the reaction was stirred for $4 \mathrm{~h}$ at $0{ }^{\circ} \mathrm{C}$. Upon work-up $58 \mathrm{mg}$ (88 \%) of the desired acid 57 was isolated as a colorless oil: $\mathrm{R}_{\mathrm{f}}=0.24$ (1:1 Hex/EtOAc); ${ }^{1} \mathrm{H}$ NMR (400 MHz, $\left.\mathrm{CDCl}_{3}\right) \delta 2.45$ (q, 2H, $J=7.3 \mathrm{~Hz}$ ), 2.41-2.29 (m, 2H), 2.13-2.09 (m, 1H), 1.90-1.84 (m, 2H), 1.46 (q, 1H, J = 12.5 Hz), 1.35-1.22 (m, 3H), 1.00 (t, 3H, $J=7.3 \mathrm{~Hz}) ;{ }^{13} \mathrm{C}$ NMR $\left(100 \mathrm{MHz}, \mathrm{CDCl}_{3}\right) \delta 213.4,181.4,49.4,42.4,33.8$, 30.2, 28.1, 27.8, 24.8, 7.7; IR ( NaCl, neat) 3180, 2937, 2861, 1735, 1707, 1448, 1413, 1378, 1264, $1218 \mathrm{~cm}^{-1}$; HRMS (FAB+) calcd for $\mathrm{C}_{10} \mathrm{H}_{17} \mathrm{O}_{3}, 185.1178$. Found 185.1181.

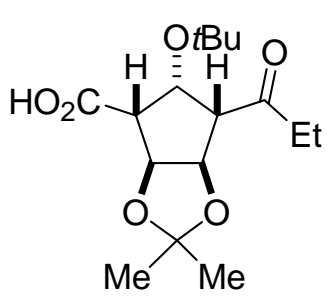

$\left(1 S^{*}, 3 R^{*}\right)$-5-tert-Butoxy-2,2-dimethyl-6-propionyl-tetrahydrocyclopenta[1,3]dioxole-4-carboxylic acid (59). According to the general procedure, $4.7 \mathrm{mg}(0.017 \mathrm{mmol})$ of $\mathrm{Ni}(\mathrm{COD})_{2}$ and $6.1 \mathrm{mg}$ $(0.021 \mathrm{mmol})$ of PYPHOS in $1 \mathrm{~mL}$ of THF was treated with $5 \mu \mathrm{L}$ $(0.042 \mathrm{mmol})$ of 4 -fluorostyrene and $45 \mu \mathrm{L}$ of $\mathrm{Et}_{2} \mathrm{Zn}(0.440 \mathrm{mmol})$ at $0{ }^{\circ} \mathrm{C}$. $50 \mathrm{mg}(0.176 \mathrm{mmol})$ of anhydride $58 \mathrm{in} 1 \mathrm{~mL}$ THF was added via syringe and the reaction was stirred for $19 \mathrm{~h}$ at $0{ }^{\circ} \mathrm{C}$. A modified work-up was used. The reaction was diluted with $\mathrm{Et}_{2} \mathrm{O}(10 \mathrm{~mL})$ washed with $1 \mathrm{M}$ aq. citric acid. The aqueous layer was separated and extracted with $\mathrm{Et}_{2} \mathrm{O}(2 \mathrm{X} 10$ $\mathrm{mL})$. Organics were combined and extracted with $1 \mathrm{M}$ aq. $\mathrm{Na}_{2} \mathrm{CO}_{3}(2 \mathrm{X} 5 \mathrm{~mL})$. Basic layer were combined and acidified with solid citric acid ( $\sim 1.3 \mathrm{~g})$. The acidified aqueous layer was extracted with $\mathrm{Et}_{2} \mathrm{O}(3 \mathrm{X} 10 \mathrm{~mL})$. Organics were combined, washed with $\mathrm{H}_{2} \mathrm{O}$ (3 X $10 \mathrm{~mL}$ ), brine, dried over $\mathrm{MgSO}_{4}$, filtered and concentrated to provide $58 \mathrm{mg}(88 \%)$ of the desired acid 59 was isolated as a colorless oil: $\mathrm{R}_{\mathrm{f}}=0.44(1: 1 \mathrm{Hex} / \mathrm{EtOAc}) ;{ }^{1} \mathrm{H}$ NMR (300 MHz, $\mathrm{CDCl}_{3}$ ) $\delta 5.23$ (dd, $1 \mathrm{H}, J=6.2,1.2 \mathrm{~Hz}$ ), 4.72 (dd, $1 \mathrm{H}, J=7.7,7.7 \mathrm{~Hz}$ ), 4.63 (d, 1H, $J=6.2 \mathrm{~Hz}$ ), 3.30 (d, 1H, $J=7.4 \mathrm{~Hz}$ ), 2.92 (dd, 1H, $J=8.2,1.0 \mathrm{~Hz}$ ), 2.60 (dq, $1 \mathrm{H}, J=18.3,7.2 \mathrm{~Hz}$ ), 2.49 (dq, 1H, $J=18.5,7.2 \mathrm{~Hz}$ ), 1.44 (s, 3H), 1.32 (s, 9H), 1.27 (s, 3H), 1.02 (t, 3H, $J=7.2 \mathrm{~Hz}) ;{ }^{13} \mathrm{C}$ NMR $\left(75 \mathrm{MHz}, \mathrm{CDCl}_{3}\right) \delta 210.0,170.5,110.0,80.6$, 78.4, 73.1, 59.7, 52.2, 38.7, 27.6, 26.5, 23.8, 7.2; IR (NaCl, neat) 3417, 2979, 2939, 1770, 1714, 1548, 1252, 1214, $1007 \mathrm{~cm}^{-1}$; HRMS (FAB+) calcd for $\mathrm{C}_{16} \mathrm{H}_{27} \mathrm{O}_{6}, 315.1808$. Found 315.1801.

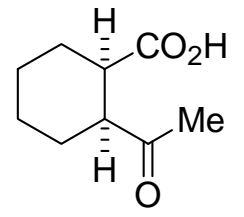

$\left(1 R^{*}, 2 S^{*}\right)$-2-acetyl-cyclohexanecarboxylic acid (S11). According to the general procedure, $11.2 \mathrm{mg}(0.0407 \mathrm{mmol})$ of $\mathrm{Ni}(\mathrm{COD})_{2}$ and $15.6 \mathrm{mg}$ $(0.0535 \mathrm{mmol})$ of PYPHOS in $1 \mathrm{~mL}$ of THF was treated with $10 \mu \mathrm{L}$ $(0.068 \mathrm{mmol})$ of 4 -(trifluoromethyl)styrene and $0.5 \mathrm{~mL}(1.0 \mathrm{M}$ solution in hexane, $0.5 \mathrm{mmol})$ of $\mathrm{Me}_{2} \mathrm{Zn}$ at $0{ }^{\circ} \mathrm{C}$. $56.0 \mathrm{mg}(0.36 \mathrm{mmol})$ of anhydride 1 in $1 \mathrm{~mL}$ THF was added via cannula and the reaction was stirred for $15 \mathrm{~min}$. at $0{ }^{\circ} \mathrm{C}$. Upon work-up $53 \mathrm{mg}$ (86\%) of desired acid $\mathbf{S 1 1}$ was isolated as a white solid: $\mathrm{mp}=71$ $73{ }^{\circ} \mathrm{C}\left(\mathrm{Et}_{2} \mathrm{O}\right)$; ${ }^{1} \mathrm{H}$ NMR (300 MHz, $\left.\mathrm{CDCl}_{3}\right) \delta$ 2.72-2.82 (m, 2H), 2.15 (s, 3H), 1.94-2.10 (m, 2H), 1.71-1.85 (m, 2H), 1.53 (m, 1H), 1.33-1.45 (m, 3H); ${ }^{13} \mathrm{C}$ NMR (75 MHz, $\left.\mathrm{CDCl}_{3}\right) \delta 209.7,180.1,50.0,42.3,27.9,26.1,25.9,23.8,23.7 ; \mathrm{IR}\left(\mathrm{NaCl}, \mathrm{CDCl}_{3}\right)$ 3084, 
2937, 1770, 1705, $1223 \mathrm{~cm}^{-1}$; HRMS (FAB+) calcd for $\mathrm{C}_{9} \mathrm{H}_{15} \mathrm{O}_{3}, 171.1021$. Found 171.1018.<smiles>O=C(O)[C@H]1CCCC[C@H]1C(=O)O</smiles>

$\left(1 R^{*}, 2 S^{*}\right)$-2-benzoyl-cyclohexanecarboxylic acid (S12). According to the general procedure, $9.5 \mathrm{mg}(0.035 \mathrm{mmol})$ of $\mathrm{Ni}(\mathrm{COD})_{2}$ and $12.2 \mathrm{mg}$ $(0.0419 \mathrm{mmol})$ of PYPHOS in $1 \mathrm{~mL}$ of THF was treated with $10 \mu \mathrm{L}$ $(0.068 \mathrm{mmol})$ of 4 -(trifluoromethyl)styrene and $86 \mathrm{mg}(0.39 \mathrm{mmol})$ of $\mathrm{Ph}_{2} \mathrm{Zn}$ in $1 \mathrm{~mL}$ THF at $0{ }^{\circ} \mathrm{C}$. $56 \mathrm{mg}(0.36 \mathrm{mmol})$ of anhydride $1 \mathrm{in} 1 \mathrm{~mL}$ THF was added via cannula and the reaction was stirred for $2 \mathrm{~h}$ at $0{ }^{\circ} \mathrm{C}$ then warmed to room temperature and stirred an additional $11 \mathrm{~h}$. Upon work-up $74 \mathrm{mg}$ (88\%) of desired acid S12 was isolated as a white solid. The acid was characterized as the corresponding methyl ester: $\mathrm{R}_{\mathrm{f}}=0.23$ (4:1 Hex/EtOAc); ${ }^{1} \mathrm{H} \mathrm{NMR}\left(300 \mathrm{MHz}, \mathrm{CDCl}_{3}\right) \delta 7.85-7.88(\mathrm{~m}$, 2H), 7.53 (m, 1H), 7.41-7.47 (m, 2H), 3.89 (m, 1H), 3.61 (s, 3H), 2.73 (ddd, 1H, $J=9.0$, 4.3, 4.3), $2.20(\mathrm{~m}, 1 \mathrm{H}), 2.07(\mathrm{~m}, 1 \mathrm{H}), 1.95(\mathrm{~m}, 1 \mathrm{H}), 1.71-1.86(\mathrm{~m}, 2 \mathrm{H}), 1.31-1.50(\mathrm{~m}$, $3 \mathrm{H}) ;{ }^{13} \mathrm{C}$ NMR (75 MHz, $\left.\mathrm{CDCl}_{3}\right) \delta$ 202.3, 174.3, 136.6, 132.4, 128.4, 128.0, 51.6, 44.4, 42.9, 27.5, 25.6, 24.3, 22.8; IR (NaCl, $\left.\mathrm{CDCl}_{3}\right)$, 2945, 1734, 1682, $1448 \mathrm{~cm}^{-1}$; HRMS (FAB+) calcd for $\mathrm{C}_{15} \mathrm{H}_{19} \mathrm{O}_{3}, 247.1334$. Found 247.1339.

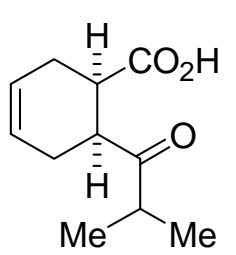

$\left(1 R^{*}, 6 S^{*}\right)-6$-Isobutyryl-cyclohex-3-enecarboxylic acid (S13).

According to the general procedure, $5.4 \mathrm{mg}(0.020 \mathrm{mmol})$ of $\mathrm{Ni}(\mathrm{COD})_{2}$ and $4.4 \mathrm{mg}(0.028 \mathrm{mmol})$ of bpy in $1 \mathrm{~mL}$ of THF was treated with $5 \mu \mathrm{L}$ (0.042 mmol) of 4-fluorostyrene and $0.4 \mathrm{~mL}(1.0 \mathrm{M}$ in hexanes, 0.400 $\mathrm{mmol})$ of $\mathrm{\imath}-\mathrm{Pr}_{2} \mathrm{Zn}$ at $0{ }^{\circ} \mathrm{C} .50 \mathrm{mg}(0.33 \mathrm{mmol})$ of anhydride 8 in $1 \mathrm{~mL}$ THF was added via cannula and the reaction was stirred for $1 \mathrm{~h}$ at $0{ }^{\circ} \mathrm{C}$. Upon work-up $51 \mathrm{mg}$ (77\%) of desired acid S13 was isolated as a colorless oil: $\mathrm{R}_{\mathrm{f}}=0.29(1: 1$ EtOAc/hex); ${ }^{1} \mathrm{H}$ NMR (400 MHz, $\left.\mathrm{CDCl}_{3}\right) \delta 5.71-5.64$ (m, 2H), 3.15 (ddd, $1 \mathrm{H}, J=6.4$, 6.4, 3.6 Hz), 2.95 (ddd, 1H, $J=6.8,6.8,3.6 \mathrm{~Hz}$ ), 2.97-2.82 (m, 1H), 2.67-2.61 (m, 1H), 2.47-2.32 (m, 3H), 1.10 (d, 3H, $J=6.8 \mathrm{~Hz}), 1.04$ (d, 3H, $J=6.8) ;{ }^{13} \mathrm{C}$ NMR (100 MHz, $\left.\mathrm{CDCl}_{3}\right) \delta 214.9,179.8,125.9,124.2$, 44.5, 39.3, 37.4, 25.7, 25.5, 19.0, 18.3; IR (NaCl, neat) 3277, 3028, 2973, 2930, 1704, 1436, 1251, $1212 \mathrm{~cm}^{-1}$; HRMS (FAB+) calcd for $\mathrm{C}_{11} \mathrm{H}_{17} \mathrm{O}_{3}, 197.1178$. Found 197.1177.<smiles>O=C(O)[C@H]1CCCC[C@H]1C(=O)Br</smiles>

$\left(1 R^{*}, 2 S^{*}\right)$-2-pentanoyl-cyclohexanecarboxylic acid methyl ester (S14). According to the general procedure, $11.4 \mathrm{mg}(0.0414 \mathrm{mmol})$ of $\mathrm{Ni}(\mathrm{COD})_{2}$ and $19.9 \mathrm{mg}$ (0.0499 mmol) of 1,2-bis(diphenylphosphino)ethane (DPPE) in $1 \mathrm{~mL}$ of THF was treated with $10 \mu \mathrm{L}(0.068 \mathrm{mmol})$ of $4-$ (trifluoromethyl)styrene and $1.0 \mathrm{~mL}(0.5 \mathrm{M}$ solution in THF, $0.5 \mathrm{mmol})$ of BuZnBr at $0{ }^{\circ} \mathrm{C} .56 \mathrm{mg}(0.36 \mathrm{mmol})$ of anhydride 1 in $0.32 \mathrm{~mL}$ THF was added via syringe and the reaction was stirred from $0{ }^{\circ} \mathrm{C}$ to room temperature for $14 \mathrm{~h}$. Work-up (1M HCl (aq.) quench followed by extraction with $\mathrm{Et}_{2} \mathrm{O}(3 \mathrm{X} 10 \mathrm{~mL})$ ) yielded $75 \mathrm{mg}$ of crude acid which was esterified with $\mathrm{CH}_{2} \mathrm{~N}_{2}$ in $\mathrm{Et}_{2} \mathrm{O}$ at $0{ }^{\circ} \mathrm{C}$. The crude methyl ester was purified via flash column chromotography (9:1 Hex/EtOAc) to yield $55 \mathrm{mg}$ (67\%) of desired ester S14 as a colorless oil: $\mathrm{R}_{\mathrm{f}}=0.40$ (4:1 Hex/EtOAc); ${ }^{1} \mathrm{H}$ NMR (300 MHz, $\left.\mathrm{CDCl}_{3}\right) \delta 3.62(\mathrm{~s}, 3 \mathrm{H}), 2.78-2.71(\mathrm{~m}, 2 \mathrm{H}), 2.44$ (dd, 2H, $\left.J=7.7,6.9 \mathrm{~Hz}\right), 2.06-1.93(\mathrm{~m}$, 2H), 1.83-1.71 (m, 2H), 1.57-1.35 (m, 6H), 1.27 (tq, 2H, $J=9.5,7.3 \mathrm{~Hz}), 0.87$ (t, 3H, $J=$ 
7.3 Hz); ${ }^{13} \mathrm{C}$ NMR (75 MHz, $\left.\mathrm{CDCl}_{3}\right) \delta 211.7,174.3$, 51.5, 49.5, 42.4, 39.9, 26.2, 26.0, 25.8, 23.9, 23.7, 22.4, 14.0; IR (NaCl, neat) 2935, 2860, 1734, 1709,1450, 1434, 1196 $\mathrm{cm}^{-1}$; HRMS (FAB+) calcd for $\mathrm{C}_{13} \mathrm{H}_{23} \mathrm{O}_{3}, 227.1647$. Found 227.1643.<smiles>CCOC(=O)CCC(=O)[C@H]1CCCC[C@H]1C(=O)O</smiles>

$\left(1 R^{*}, 2 S^{*}\right)$-2-(3-ethoxycarbonyl-propionyl)cyclohexanecarboxylic acid methyl ester (S15). According to the general procedure, $9.7 \mathrm{mg}(0.035 \mathrm{mmol})$ of $\mathrm{Ni}(\mathrm{COD})_{2}$ and $17.3 \mathrm{mg}$ ( $0.0434 \mathrm{mmol})$ of 1,2-bis(diphenylphosphino)ethane (DPPE) in $1 \mathrm{~mL}$ of THF was treated with $10 \mu \mathrm{L}(0.068 \mathrm{mmol})$ of 4-(trifluoromethyl)styrene and $1.0 \mathrm{~mL}(0.5 \mathrm{M}$ solution in THF, $0.5 \mathrm{mmol})$ of 3-ethoxy-3oxopropylxinc bromide at $0{ }^{\circ} \mathrm{C} .56 \mathrm{mg}(0.36 \mathrm{mmol})$ of anhydride $1 \mathrm{in} 0.21 \mathrm{~mL}$ THF was added via syringe and the reaction was stirred from $0{ }^{\circ} \mathrm{C}$ to room temperature for $14 \mathrm{~h}$. Work-up (1M HCl (aq.) quench followed by extraction with $\mathrm{Et}_{2} \mathrm{O}$ (3 X10 mL)) yielded $69.0 \mathrm{mg}$ of crude acid which was esterified with $\mathrm{CH}_{2} \mathrm{~N}_{2}$ in $\mathrm{Et}_{2} \mathrm{O}$ at $0{ }^{\circ} \mathrm{C}$. The crude methyl ester was purified via flash column chromotography (17:3 Hex/EtOAc) to yield $50 \mathrm{mg}$ (53\%) of desired ester $\mathbf{S 1 5}$ as a colorless oil: $\mathrm{R}_{\mathrm{f}}=0.21$ (4:1 Hex/EtOAc); ${ }^{1} \mathrm{H}$ NMR (300 MHz, $\left.\mathrm{CDCl}_{3}\right) \delta 4.10$ (q, 2H, $J=7.1 \mathrm{~Hz}$ ), 3.62 (s, 3H), 2.89-2.72 (m, 4H), 2.55 (ddd, 2H, $J=6.5,6.3,2.7 \mathrm{~Hz}$ ), 2.08-1.95 (m, 2H), 1.88-1.69 (m, 2H), 1.54-1.35 (m, 4H), 1.23 (t, 3H, $J=7.1 \mathrm{~Hz}$ ); ${ }^{13} \mathrm{C}$ NMR $\left(75 \mathrm{MHz}, \mathrm{CDCl}_{3}\right) \delta$ 209.6, 174.2, 172.7, 60.5, 51.6, 49.4, 42.5, 34.9, 28.0, 26.4, 25.8, 23.8, 23.7, 14.2; IR (NaCl, neat) 2937, 2858, 1732, $1713,1450,1373,1198 \mathrm{~cm}^{-1}$; HRMS (FAB+) calcd for $\mathrm{C}_{14} \mathrm{H}_{23} \mathrm{O}_{5}, 271.1545$. Found 271.1544 .

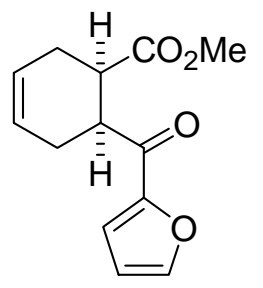

$(1 R, 6 S)$ 6-(Furan-2-carbonyl)-cyclohex-3-enecarboxylic acid methyl ester (S16). Preparation of difurylzinc: A flame dried round bottom flask was charged with $0.160 \mathrm{~mL}(2.20 \mathrm{mmol})$ of freshly distilled furan in $1 \mathrm{~mL}$ of THF. The vessel was cooled to $0{ }^{\circ} \mathrm{C}$ and $0.63 \mathrm{~mL}(1.0 \mathrm{mmol})$ of $n \mathrm{BuLi}(1.6 \mathrm{M}$ in hexanes) was added via syringe. After stirring for 30 min., $136 \mathrm{mg}$ (1.00 mmol) of $\mathrm{ZnCl}_{2}$ in $1 \mathrm{~mL}$ of $\mathrm{THF}$ was added via cannula. The resulting solution was stirred an additional $30 \mathrm{~min}$. before use providing a $0.38 \mathrm{M}$ solution of difurylzinc. According to the general procedure, $4.5 \mathrm{mg}(0.016 \mathrm{mmol})$ of $\mathrm{Ni}(\mathrm{COD})_{2}$ and $3.2 \mathrm{mg}(0.021 \mathrm{mmol})$ of bpy in $1 \mathrm{~mL}$ of THF was treated with $5 \mu \mathrm{L}$ ( $0.042 \mathrm{mmol})$ 4-fluorostyrene, nucleophile solution was added followed by addition of 50 $\mathrm{mg}(0.33 \mathrm{mmol})$ of anhydride 8 in $0.25 \mathrm{~mL}$ THF. The reaction was stirred for $4 \mathrm{~h}$ at $0{ }^{\circ} \mathrm{C}$. Upon work-up the crude acid was converted corresponding methyl ester. Purification (9:1 Hex/EtOAc) yielded $47 \mathrm{mg}(61 \%)$ of product ester $\mathbf{S 1 6}$ as a colorless oil. $\mathrm{R}_{\mathrm{f}}=0.17$ (4:1 Hex/EtOAc); ${ }^{1} \mathrm{H}$ NMR (300 MHz, $\mathrm{CDCl}_{3}$ ) $\delta 7.54$ (d, 1H, J = $1.8 \mathrm{~Hz}$ ), 7.18 (d, 1H, J $=4.0 \mathrm{~Hz}), 6.52(\mathrm{dd}, 1 \mathrm{H}, \mathrm{J}=3.7,1.8 \mathrm{~Hz}), 5.71-5.77(\mathrm{~m}, 1 \mathrm{H}), 5.65-5.69(\mathrm{~m}, 1 \mathrm{H}), 3.75$ (ddd, $1 \mathrm{H}, \mathrm{J}=6.6,6.6,4.0 \mathrm{~Hz}$ ), 3.62 (s, 3H), 3.06 (ddd, 1H, J = 6.6, 6.6, 3.7), 2.66-2.77 (m, 1H), 2.39-2.61 (m, 3H); $\left.{ }^{13} \mathrm{C} \mathrm{NMR} \mathrm{(75} \mathrm{MHz,} \mathrm{CDCl}_{3}\right) \delta$ 189.7, 173.7, 152.3, 145.6, 125.4, 123.9, 116.8, 112.1, 51.7, 42.0, 39.6, 26.2, 25.8; IR (NaCl, neat) 3134, 3028, 2951, 2918, 1736, 1676, 1568, 1468, 1435, 1202, $1016 \mathrm{~cm}^{-1}$; HRMS (FAB+) calcd for $\mathrm{C}_{13} \mathrm{H}_{15} \mathrm{O}_{4}, 235.0970$. Found 235.0980. 


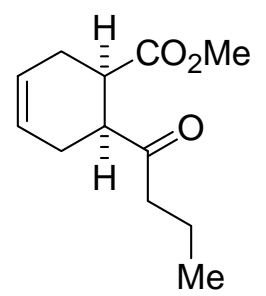

$\left(1 R^{*}, 6 S^{*}\right)$ 6-Butyryl-cyclohex-3-enecarboxylic acid methyl ester

(S17). Preparation of dipropylzinc: A flame dried round bottom flask was charged with $0.44 \mathrm{~mL}\left(2.0 \mathrm{M}\right.$ in $\left.\mathrm{Et}_{2} \mathrm{O}, 0.880 \mathrm{mmol}\right)$ of $n-$ propylmagnisium bromide in $1 \mathrm{~mL}$ of THF. Upon cooling to $0{ }^{\circ} \mathrm{C}, 62.0$ $\mathrm{mg}$ of $\mathrm{ZnCl}_{2}(0.440 \mathrm{mmol})$ in $1 \mathrm{~mL}$ of THF was added via cannula and reaction stirred for $0.5 \mathrm{~h}$ before warming to ambient temperature and stirring an additional $1.5 \mathrm{~h}$ before use. According to the general procedure, $5.0 \mathrm{mg}(0.018$ $\mathrm{mmol})$ of $\mathrm{Ni}(\mathrm{COD})_{2}$ and $3.4 \mathrm{mg}(0.022 \mathrm{mmol})$ of bpy in $1 \mathrm{~mL}$ of THF was treated with 5 $\mu \mathrm{L}(0.042 \mathrm{mmol}) 4$-fluorostyrene, nucleophile solution was added via cannula followed by addition of $55 \mathrm{mg}(0.36 \mathrm{mmol})$ of anhydride 8 in $1.0 \mathrm{~mL}$ THF. The reaction was stirred for $4 \mathrm{~h}$ at $0{ }^{\circ} \mathrm{C}$. Upon work-up the crude acid was converted corresponding methyl ester by treatment with $\mathrm{TMSCHN}_{2}$. Purification (9:1 Hex/EtOAc) yielded $47 \mathrm{mg}(62 \%)$ of product ester $\mathrm{S17}$ as a colorless oil: $\mathrm{R}_{\mathrm{f}}=0.26$ (4:1 Hex/EtOAc); ${ }^{1} \mathrm{H}$ NMR (400 MHz, $\mathrm{CDCl}_{3}$ ) $\delta 5.66$ (s, 2H), 3.64 (s, 3H), 3.02 (ddd, $1 \mathrm{H}, J=6.2,6.2,3.6 \mathrm{~Hz}$ ), 2.89 (ddd, $1 \mathrm{H}, J$ = 6.6, 6.6, 3.6 Hz), 2.60-2.51 (m, 2H), 2.46 (t, 2H, $J=7.2 \mathrm{~Hz}), 2.42-2.31(\mathrm{~m}, 2 \mathrm{H}), 1.63-$ 1.54 (m, 2H), 0.89 (t, 3H, $J=7.5 \mathrm{~Hz}) ;{ }^{13} \mathrm{C} \mathrm{NMR}\left(100 \mathrm{MHz}, \mathrm{CDCl}_{3}\right) \delta 210.8,174.0$, 125.7, 124.5, 51.7, 46.5, 41.8, 39.3, 26.1, 25.2, 17.0, 13.7; IR (NaCl, neat) 3031, 2963, $2875,1734,1711,1437,1368,1202,1026 \mathrm{~cm}^{-1}$; HRMS (FAB+) calcd for $\mathrm{C}_{12} \mathrm{H}_{19} \mathrm{O}_{3}$, 211.1334 Found 211.1338.

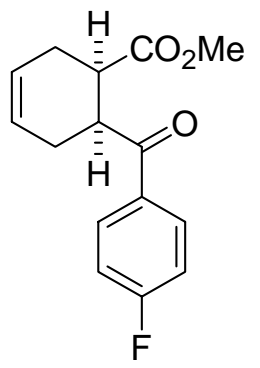

$\left(1 R^{*}, 6 S^{*}\right)$ 6-(4-Fluoro-benzoyl)-cyclohex-3-enecarboxylic acid methyl ester (S18). Preparation of di(4-fluoropheny)zinc: A flame dried round bottom flask was charged with $0.44 \mathrm{~mL}\left(2.0 \mathrm{M}\right.$ in $\mathrm{Et}_{2} \mathrm{O}$, $0.880 \mathrm{mmol}$ ) of 4-fluorophenylmagnisium bromide in $1 \mathrm{~mL}$ of THF. Upon cooling to $0{ }^{\circ} \mathrm{C}, 100 \mathrm{mg}$ of $\mathrm{ZnBr}_{2}(0.440 \mathrm{mmol})$ in $1 \mathrm{~mL}$ of $\mathrm{THF}$ was added via cannula and reaction stirred for $0.5 \mathrm{~h}$ before warming to ambient temperature and stirring an additional $1.5 \mathrm{~h}$ before use.

According to the general procedure, $5.0 \mathrm{mg}(0.018 \mathrm{mmol})$ of $\mathrm{Ni}(\mathrm{COD})_{2}$ and $3.4 \mathrm{mg}(0.022 \mathrm{mmol})$ of bpy in $1 \mathrm{~mL}$ of THF was treated with $5 \mu \mathrm{L}(0.042 \mathrm{mmol}) 4-$ fluorostyrene, nucleophile solution was added via cannula followed by addition of $55 \mathrm{mg}$ ( $0.36 \mathrm{mmol})$ of anhydride $8 \mathrm{in} 1.0 \mathrm{~mL}$ THF. The reaction was stirred for $4 \mathrm{~h}$ at $0{ }^{\circ} \mathrm{C}$. Upon work-up the crude acid was converted corresponding methyl ester by treatment with TMSCHN 2 . Purification (9:1 Hex/EtOAc) yielded $64 \mathrm{mg}(68 \%)$ of product ester S18 as a colorless solid: $\mathrm{mp}=68-71{ }^{\circ} \mathrm{C} ; \mathrm{R}_{\mathrm{f}}=0.19$ (4:1 Hex/EtOAc); ${ }^{1} \mathrm{H}$ NMR (400 $\left.\mathrm{MHz} \mathrm{CDCl}_{3}\right) \delta$ 7.92-7.88 (m, 2H), 7.15-7.11 (m, 2H), 5.79-5.75 (m, 1H), 5.66-5.62 (m, 1H), 3.93 (ddd, 1H, $J=6.2,6.2,4.1 \mathrm{~Hz}$ ), 3.63 (s, 3H), 3.00 (ddd, 1H, $J=6.6,6.6,4.1$ $\mathrm{Hz}), 2.79-2.72(\mathrm{~m}, 1 \mathrm{H}), 2.49-2.44(\mathrm{~m}, 3 \mathrm{H}) ;{ }^{13} \mathrm{C} \mathrm{NMR}\left(100 \mathrm{MHz}, \mathrm{CDCl}_{3}\right) \delta 200.0,174.0$, $165.4\left(\mathrm{~d}, J_{C-F}=254.7 \mathrm{~Hz}\right), 132.9$ (d, $\left.J_{C-F}=3.7 \mathrm{~Hz}\right), 130.8$ (d, $\left.J_{C-F}=9.2 \mathrm{~Hz}\right), 124.8\left(\mathrm{~d}, J_{C-}\right.$ $\left.F_{F}=192.4 \mathrm{~Hz}\right), 115.8,115.6,51.8,41.3$, 39.8, 26.4, 25.9; IR $\left(\mathrm{NaCl}\right.$, dep. $\left.\mathrm{CHCl}_{3}\right)$ 3028, 2951, 2920, 1732, 1686, 1596, 1435, 1223, $1157 \mathrm{~cm}^{-1}$; HRMS (FAB+) calcd for $\mathrm{C}_{15} \mathrm{H}_{16} \mathrm{FO}_{3}, 263.1083$. Found 263.1084. 
<smiles>CC(=O)C1CCCCC1C(=O)c1ccccc1C</smiles>

$\left(1 R^{*}, 2 S^{*}\right)$ 2-(2-Methyl-benzoyl)-cyclohexanecarboxylic acid methyl ester (S19). Preparation of di(o-tolyl)zinc: A flame dried round bottom flask was charged with $0.12 \mathrm{~mL}$ of 2-bromotoluene $(1.0 \mathrm{mmol})$ in $3 \mathrm{~mL}$ of THF. Upon cooling to $-78^{\circ} \mathrm{C}, 0.66 \mathrm{~mL}(1.6 \mathrm{M}$ in hexanes, $1.05 \mathrm{mmol}$ ) were added dropwise via syringe. After $30 \mathrm{~min}, 114 \mathrm{mg}$ of $\mathrm{ZnBr}_{2}(0.510 \mathrm{mmol})$ in $1 \mathrm{~mL}$ of THF was added via cannula and reaction stirred for $0.5 \mathrm{~h}$ before warming to ambient temperature and stirring an additional $1.5 \mathrm{~h}$ before use. According to the general procedure, $5.8 \mathrm{mg}(0.021$ $\mathrm{mmol})$ of $\mathrm{Ni}(\mathrm{COD})_{2}$ and $4.3 \mathrm{mg}(0.028 \mathrm{mmol})$ of bpy in $1 \mathrm{~mL}$ of THF was treated with 5 $\mu \mathrm{L}(0.042 \mathrm{mmol})$ 4-fluorostyrene, nucleophile solution was added via cannula followed by addition of $56 \mathrm{mg}(0.36 \mathrm{mmol})$ of anhydride 1 in $1.0 \mathrm{~mL}$ THF. The reaction was stirred for $2 \mathrm{~h}$ at $0{ }^{\circ} \mathrm{C}$. Upon work-up the crude acid was converted corresponding methyl ester by treatment with $\mathrm{TMSCHN}_{2}$. Purification (3:1 $\left.\mathrm{CH}_{2} \mathrm{Cl}_{2} / \mathrm{Hex}\right)$ yielded $60 \mathrm{mg}(63 \%)$ of product ester S19 as a colorless oil: $\mathrm{R}_{\mathrm{f}}=0.17\left(\mathrm{CH}_{2} \mathrm{Cl}_{2}\right) ;{ }^{1} \mathrm{H} \mathrm{NMR}\left(400 \mathrm{MHz}, \mathrm{CDCl}_{3}\right)$ $\delta 7.48(\mathrm{~d}, 1 \mathrm{H}, J=7.3 \mathrm{~Hz}$ ), 7.32 (t, $1 \mathrm{H}, J=8.3 \mathrm{~Hz}), 7.24-7.20(\mathrm{~m}, 2 \mathrm{H}), 3.65$ (s, 3H), 3.633.61 (m, 1H), 2.79-2.74 (m, 1H), 2.41 (s, 3H), 2.18-2.10 (m, 1H), 1.98-1.89 (m, 2H), 1.75-1.63 (m, 2H), 1.45-1.34 (m, 3H); $\left.{ }^{13} \mathrm{C} \mathrm{NMR} \mathrm{(100} \mathrm{MHz,} \mathrm{CDCl}_{3}\right) \delta 206.8,174.5$, 138.3, 137.3, 131.6, 130.3, 127.2, 125.4, 51.6, 47.5, 42.5, 26.5, 25.8, 24.2, 23.5, 20.2; IR (NaCl, neat) 2945, 2858, 1742, 1691, 1450, 1296, 1219, 1040, $968 \mathrm{~cm}^{-1}$; HRMS (FAB+) calcd for $\mathrm{C}_{16} \mathrm{H}_{21} \mathrm{O}_{3}$, 261.1491. Found 261.1492.<smiles>COc1cc(C(=O)C(C)C(C)C(=O)O)cc(OC)c1OC</smiles>

(2S*, 3R*)-2,3-Dimethyl-4-oxo-4-(3,4,5-trimethoxyphenyl)-butyric acid (S20). A flame-dried round bottom flask charged with $2.04 \mathrm{~g}(8.26 \mathrm{mmol})$ of aryl bromide $\mathbf{x x}$ in $25 \mathrm{~mL}$ of THF was cooled to $-78^{\circ} \mathrm{C}$ and $5.44 \mathrm{~mL}$ of $n$-BuLi (1.6 $\mathrm{M}$ in hexanes, $8.70 \mathrm{mmol}$ ) was added dropwise via syringe. The mixture was stirred for $0.5 \mathrm{~h}$ at $-78^{\circ} \mathrm{C}$ before the addition of $608 \mathrm{mg}$ of $\mathrm{ZnCl}_{2}$ (4.46 mmol) in $8 \mathrm{~mL}$ of THF via cannula and warming to room temperature over $0.5 \mathrm{~h}$. In a separate flask, a solution of $52 \mathrm{mg}$ of $\mathrm{Ni}(\mathrm{COD})_{2}(0.19 \mathrm{mmol}), 35 \mathrm{mg}$ of 2,2'bipyridyl $(0.22 \mathrm{mmol})$ in $5 \mathrm{~mL}$ of THF were stirred for $15 \mathrm{~min}$. at room temperature before the addition of $50 \mu \mathrm{L}(0.42 \mathrm{mmol})$ of 4 -fluorostyrene via syringe. The solution of diarylzinc reagent was cooled to $0^{\circ} \mathrm{C}$ before the addition of the deep purple catalyst solution via cannula. A solution of $490 \mathrm{mg}$ of meso dimethylsuccinic anhydride (3.82 $\mathrm{mmol}$ ) in $5 \mathrm{~mL}$ of THF was then added via cannula. The resulting reaction mixture was allowed to stir at $0{ }^{\circ} \mathrm{C}$ for $4 \mathrm{~h}$. The reaction mixture was partitioned between $\mathrm{Et}_{2} \mathrm{O}$ (50 $\mathrm{mL})$ and $1 \mathrm{M}$ aq. $\mathrm{HCl}(50 \mathrm{~mL})$ and transferred to a sepratory funnel where the layers were separated. The aqueous layer was extracted with $\mathrm{Et}_{2} \mathrm{O}(2 \mathrm{X} 10 \mathrm{~mL})$, the organics were combined and extracted with $1 \mathrm{M} \mathrm{NaCO}_{3}(4 \mathrm{X} 15 \mathrm{~mL})$. The basic aqueous layers were combined and brought to $\mathrm{pH} \sim 1$ with conc. $\mathrm{HCl}$. The acidified aqueous layer was extracted with $\mathrm{Et}_{2} \mathrm{O}$ (4 X $50 \mathrm{~mL}$ ), organics were combined, washed with brine, dried over $\mathrm{MgSO}_{4}$, filtered, and concentrated in vacuo to provide $1.02 \mathrm{~g}(3.44 \mathrm{mmol}, 90 \%)$ of the desired product as a white solid: $\mathrm{mp}=115-117^{\circ} \mathrm{C} . \mathrm{R}_{\mathrm{f}}=0.26(1: 1 \mathrm{Hex} / \mathrm{EtOAc}) ;{ }^{1} \mathrm{H}$ NMR (400 MHz, $\mathrm{CDCl}_{3}$ ) $\delta 7.23$ (s, 2H); 3.93 (s, 9H); 3.67 (dq, 1H, J = 7.2, 7.2 Hz); 2.99 (dq, $1 \mathrm{H}, J=7.2,7.2 \mathrm{~Hz}) ; 1.27$ (d, 3H, $J=7.0 \mathrm{~Hz}) ; 1.21$ (d, 3H, $J=7.0 \mathrm{~Hz}) ;{ }^{13} \mathrm{C}$ NMR $\left(100 \mathrm{MHz}, \mathrm{CDCl}_{3}\right) \delta$ 201.7, 180.6, 153.2, 143.0, 131.2, 106.0, 61.0, 56.3, 43.1, 42.1, 
42.4, 16.8, 16.1; IR (NaCl, neat), 3302, 2978, 2941, 1703, 1672, 1581, 1414, $1128 \mathrm{~cm}^{-1}$; HRMS (FAB+) calcd for $\mathrm{C}_{15} \mathrm{H}_{21} \mathrm{O}_{6}, 297.1338$. Found 297.1332.<smiles>COc1cc(C(=O)C(C)C(C)C(=O)O)cc2c1OCO2</smiles>

(2S*, 3R*)-4-(7-Methoxy-benzo[1,3]dioxol-5-yl)-2,3dimethyl-4-oxo-butyric acid (S21). A flame-dried round bottom flask charged with $1.91 \mathrm{~g}(8.27 \mathrm{mmol})$ of aryl bromide $\mathbf{x x}$ in $25 \mathrm{~mL}$ of $\mathrm{THF}$ was cooled to $-78{ }^{\circ} \mathrm{C}$ and 5.45 $\mathrm{mL}$ of $n$-BuLi (1.6 M in hexanes, $8.72 \mathrm{mmol}$ ) was added dropwise via syringe. The mixture was stirred for $0.5 \mathrm{~h}$ at $-78^{\circ} \mathrm{C}$ before the addition of $606 \mathrm{mg}$ of $\mathrm{ZnCl}_{2}$ (4.45 mmol) in $8 \mathrm{~mL}$ of THF via cannula and warming to room temperature over $0.5 \mathrm{~h}$. In a separate flask, a solution of $53 \mathrm{mg}$ of $\mathrm{Ni}(\mathrm{COD})_{2}(0.19$ mmol), $37 \mathrm{mg}$ of 2,2'-bipyridyl ( $0.24 \mathrm{mmol})$ in $5 \mathrm{~mL}$ of THF were stirred for $15 \mathrm{~min}$. at room temperature before the addition of $50 \mu \mathrm{L}(0.42 \mathrm{mmol})$ of 4 -fluorostyrene via syringe. The solution of diarylzinc reagent was cooled to $0^{\circ} \mathrm{C}$ before the addition of the deep purple catalyst solution via cannula. A solution of $484 \mathrm{mg}$ of meso dimethylsuccinic anhydride ( $3.78 \mathrm{mmol}$ ) in $5 \mathrm{~mL}$ of THF was then added via cannula. The resulting reaction mixture was allowed to stir at $0{ }^{\circ} \mathrm{C}$ for $15 \mathrm{~h}$. The reaction mixture was partitioned between $\mathrm{Et}_{2} \mathrm{O}(50 \mathrm{~mL})$ and $1 \mathrm{M}$ aq. $\mathrm{HCl}(50 \mathrm{~mL})$ and transferred to a sepratory funnel where the layers were separated. The aqueous layer was extracted with $\mathrm{Et}_{2} \mathrm{O}(2 \mathrm{X} 10 \mathrm{~mL})$, the organics were combined and extracted with $1 \mathrm{M} \mathrm{NaCO}_{3}(4 \mathrm{X} 15$ $\mathrm{mL}$ ). The basic aqueous layers were combined and brought to $\mathrm{pH} \sim 1$ with conc. HCl. The acidified aqueous layer was extracted with $\mathrm{Et}_{2} \mathrm{O}(4 \mathrm{X} 50 \mathrm{~mL})$, organics were combined, washed with brine, dried over $\mathrm{MgSO}_{4}$, filtered, and concentrated in vacuo to provide $1.02 \mathrm{~g}$ (3.64 mmol, 96\%) of the desired product as a viscous oil that solidified upon standing: $93-95{ }^{\circ} \mathrm{C} . \mathrm{R}_{\mathrm{f}}=0.30$ (1:1 Hex/EtOAc); ${ }^{1} \mathrm{H} \mathrm{NMR}\left(400 \mathrm{MHz}, \mathrm{CDCl}_{3}\right) \delta$ 7.90 (d, 1H, $J=1.3 \mathrm{~Hz}$ ); 7.17 (d, 1H, $J=1.3 \mathrm{~Hz}$ ); 6.08 (s, 2H); 3.96 (s, 3H); 3.60 (dq, $1 \mathrm{H}, J=7.0,7.0 \mathrm{~Hz}$ ); 2.96 (dq, $1 \mathrm{H}, J=7.0,7.0 \mathrm{~Hz}) ; 1.25$ (d, 3H, $J=7.0 \mathrm{~Hz}) ; 1.20$ (d, 3H, $J=7.0 \mathrm{~Hz}) ;{ }^{13} \mathrm{C}$ NMR $\left(100 \mathrm{MHz}, \mathrm{CDCl}_{3}\right) \delta 201.0,180.6,149.1,143.7,140.2,131.0$, 109.3, 103.0, 102.5, 56.7, 43.2, 42.4, 16.7, 16.1; IR (NaCl, neat), 3174, 2978, 2941, 1707, 1674, 1628, 1429, 1319, 1140, $1097 \mathrm{~cm}^{-1}$; HRMS (FAB+) calcd for $\mathrm{C}_{14} \mathrm{H}_{17} \mathrm{O}_{6}, 281.1025$. Found 281.1022.

\section{Nickel (II) Precatalyst}

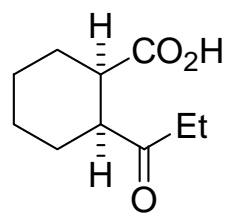

$\left(1 R^{*}, 2 S^{*}\right)$-2-propionyl-cyclohexanecarboxylic acid (2). A flame-dried round bottom flask equipped with a magnetic stir bar was charged with 39 $\mathrm{mg}(0.15 \mathrm{mmol})$ of anhydrous $\mathrm{Ni}(\mathrm{acac})_{2}$ and $29 \mathrm{mg}(0.18 \mathrm{mmol})$ of bpy. The reaction flask was then placed under vacuum for five minutes and then refilled with dry argon. After 3 vacuum/argon cycles the flask was placed under a static argon atmosphere. $10 \mathrm{~mL}$ of THF were added via syringe and the reaction mixture was cooled to $0{ }^{\circ} \mathrm{C}$ before adding $1.70 \mathrm{~mL}$ (16.6 mmol) of $\mathrm{Et}_{2} \mathrm{Zn}$ dropwise via syringe followed by addition of $44 \mu \mathrm{L}(0.30 \mathrm{mmol})$ of 4 -(trifluoromethyl)styrene. After $15 \mathrm{~min}$., an additional $30 \mathrm{~mL}$ of THF were added followed by the addition of $2.31 \mathrm{~g}$ (15.0 mmol) of anhydride 1 in $10 \mathrm{~mL}$ of THF via cannula to the deep green reaction mixture. 
The reaction was allowed to stir at $0{ }^{\circ} \mathrm{C}$ for $20 \mathrm{~h}$ (no SM by TLC). The reaction was then diluted with $\mathrm{Et}_{2} \mathrm{O}(50 \mathrm{~mL})$ and washed with $50 \mathrm{~mL}$ of $1 \mathrm{M}$ aq. $\mathrm{HCl}$. The aqueous layer was separated and extracted with $\mathrm{Et}_{2} \mathrm{O}(2 \mathrm{X} 25 \mathrm{~mL})$. Organic extracts were combined and extracted with $1 \mathrm{M}$ aq. $\mathrm{Na}_{2} \mathrm{CO}_{3}(5 \mathrm{X} 10 \mathrm{~mL})$. Basic aqueous layers were combined and acidified with conc. HCl. The resulting heterogeneous solution was extracted with $\mathrm{Et}_{2} \mathrm{O}$ (3 X $50 \mathrm{~mL}$ ). The organic extracts were combined, washed with brine, dried over $\mathrm{MgSO}_{4}$, filtered, and concentrated in vacuuo to yield $2.65 \mathrm{~g}$ (96 \%) of the desired acid 2 as a white solid identical to material derived from the standard procedure.<smiles>CCC(=O)[C@H]1CC=CC[C@H]1C(=O)O</smiles>

$\left(1 R^{*}, 2 S^{*}\right)$-2-propionyl-cyclohexanecarboxylic acid (9). A flame-dried round bottom flask equipped with a magnetic stir bar was charged with 39 $\mathrm{mg}(0.15 \mathrm{mmol})$ of anhydrous $\mathrm{Ni}(\mathrm{acac})_{2}$ and $29 \mathrm{mg}(0.18 \mathrm{mmol})$ of bpy. The reaction flask was then placed under vacuum for five minutes and then refilled with dry argon. After 3 vacuum/argon cycles the flask was placed under a static argon atmosphere. $10 \mathrm{~mL}$ of THF were added via syringe and the reaction mixture was cooled to $0{ }^{\circ} \mathrm{C}$ before adding $1.70 \mathrm{~mL}$ (16.6 mmol) of $\mathrm{Et}_{2} \mathrm{Zn}$ dropwise via syringe followed by addition of $44 \mu \mathrm{L}(0.30 \mathrm{mmol})$ of 4 -(trifluoromethyl)styrene. After $15 \mathrm{~min}$., an additional $30 \mathrm{~mL}$ of THF were added followed by the addition of $2.28 \mathrm{~g}$ (15.0 mmol) of anhydride 8 in $10 \mathrm{~mL}$ of THF via cannula to the deep green reaction mixture. The reaction was allowed to stir at $0{ }^{\circ} \mathrm{C}$ for $20 \mathrm{~h}$ (no SM by TLC). The reaction was then diluted with $\mathrm{Et}_{2} \mathrm{O}(50 \mathrm{~mL})$ and washed with $50 \mathrm{~mL}$ of $1 \mathrm{M}$ aq. $\mathrm{HCl}$. The aqueous layer was separated and extracted with $\mathrm{Et}_{2} \mathrm{O}(2 \mathrm{X} 25 \mathrm{~mL})$. Organic extracts were combined and extracted with $1 \mathrm{M}$ aq. $\mathrm{Na}_{2} \mathrm{CO}_{3}(5 \times 10 \mathrm{~mL})$. Basic aqueous layers were combined and acidified with conc. $\mathrm{HCl}$. The resulting heterogeneous solution was extracted with $\mathrm{Et}_{2} \mathrm{O}$ (3 X $50 \mathrm{~mL}$ ). The organic extracts were combined, washed with brine, dried over $\mathrm{MgSO}_{4}$, filtered, and concentrated in vacuuo to yield $2.61 \mathrm{~g}$ (95 \%) of the desired acid 9 as a white solid identical to material derived from the standard procedure.<smiles>CCC(=O)CC(C)CC(=O)O</smiles>

3-methyl-5-oxo-heptanoic acid (43). A flame-dried round bottom flask equipped with a magnetic stir bar was charged with $50 \mathrm{mg}$ ( $0.20 \mathrm{mmol})$ of anhydrous $\mathrm{Ni}(\text { acac })_{2}$ and $65 \mathrm{mg}(0.22 \mathrm{mmol})$ of bpy. The reaction flask was then placed under vacuum for five minutes and then refilled with dry argon. After 3 vacuum/argon cycles the flask was placed under a static argon atmosphere. $5 \mathrm{~mL}$ of THF were added via syringe and the reaction mixture was cooled to $0{ }^{\circ} \mathrm{C}$ before adding $0.48 \mathrm{~mL}(4.7 \mathrm{mmol})$ of $\mathrm{Et}_{2} \mathrm{Zn}$ dropwise via syringe followed by addition of $50 \mu \mathrm{L}(0.42 \mathrm{mmol})$ of 4-(trifluoromethyl)styrene. After $15 \mathrm{~min}$., an additional $5 \mathrm{~mL}$ of THF were added followed by the addition of $505 \mathrm{mg}$ (4.00 mmol) of anhydride 42 in $3 \mathrm{~mL}$ of THF via cannula to the deep green reaction mixture. The reaction was allowed to stir at $0{ }^{\circ} \mathrm{C}$ for $4 \mathrm{~h}$ (no SM by TLC). The reaction was then diluted with $\mathrm{Et}_{2} \mathrm{O}$ $(20 \mathrm{~mL})$ and washed with $20 \mathrm{~mL}$ of $1 \mathrm{M}$ aq. $\mathrm{HCl}$. The aqueous layer was separated and extracted with $\mathrm{Et}_{2} \mathrm{O}$ ( 2 X $\left.10 \mathrm{~mL}\right)$. Organic extracts were combined and extracted with $1 \mathrm{M}$ aq. $\mathrm{Na}_{2} \mathrm{CO}_{3}(2 \mathrm{X} 10 \mathrm{~mL})$. Basic aqueous layers were combined and acidified with conc. $\mathrm{HCl}$. The resulting heterogeneous solution was extracted with $\mathrm{Et}_{2} \mathrm{O}(3 \mathrm{X} 20 \mathrm{~mL})$. The organic extracts were combined, washed with brine, dried over $\mathrm{MgSO}_{4}$, filtered, and 
concentrated in vacuuo to yield $600 \mathrm{mg}$ (96\%) of the desired acid 43 as a colorless oil identical to material derived from the standard procedure. 
${ }^{1} \mathrm{H}$ and ${ }^{13} \mathrm{C}$ sprectra for $\mathbf{3 4}$ :
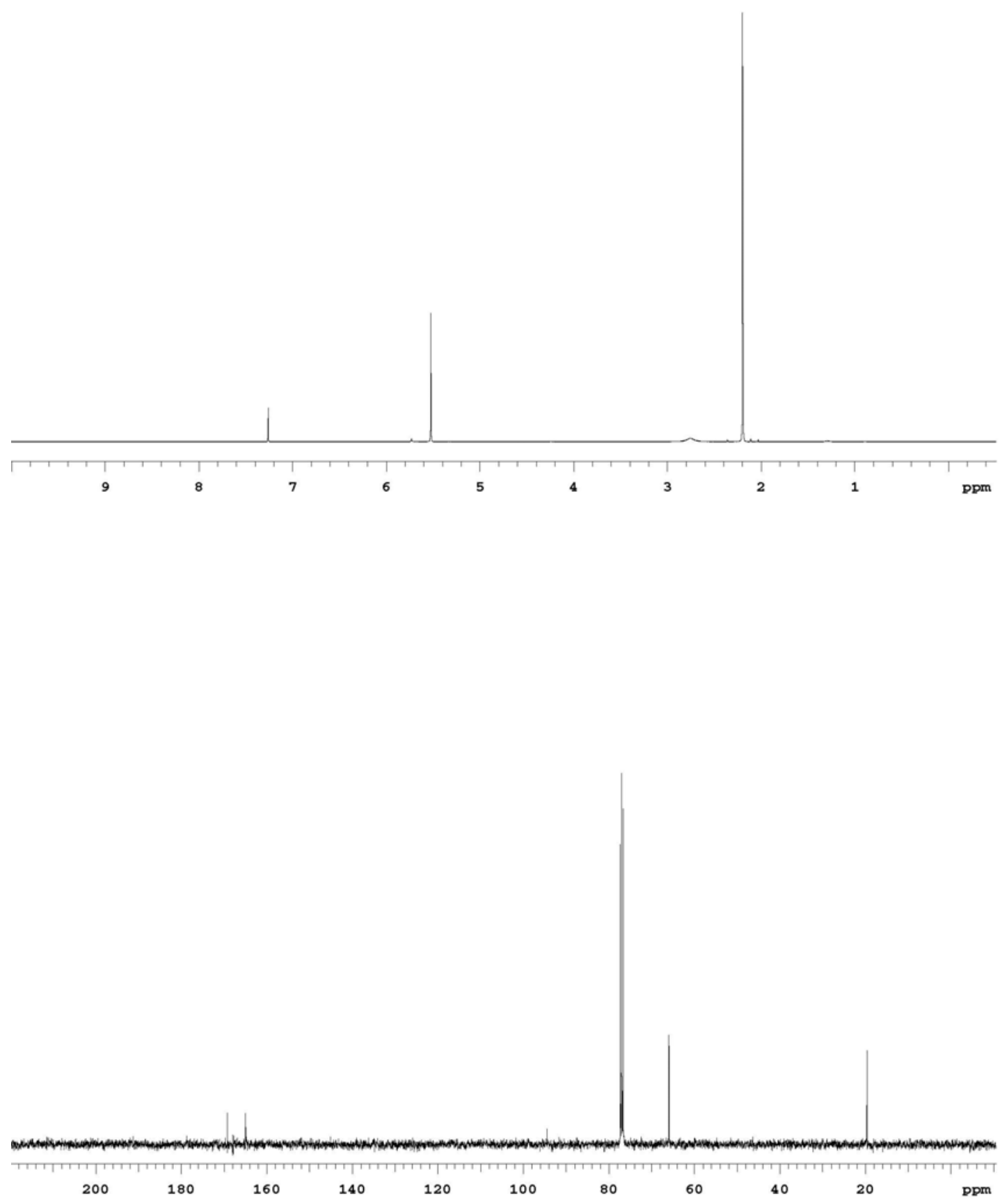
${ }^{1} \mathrm{H}$ and ${ }^{13} \mathrm{C}$ sprectra for $\mathbf{4 0}$ :
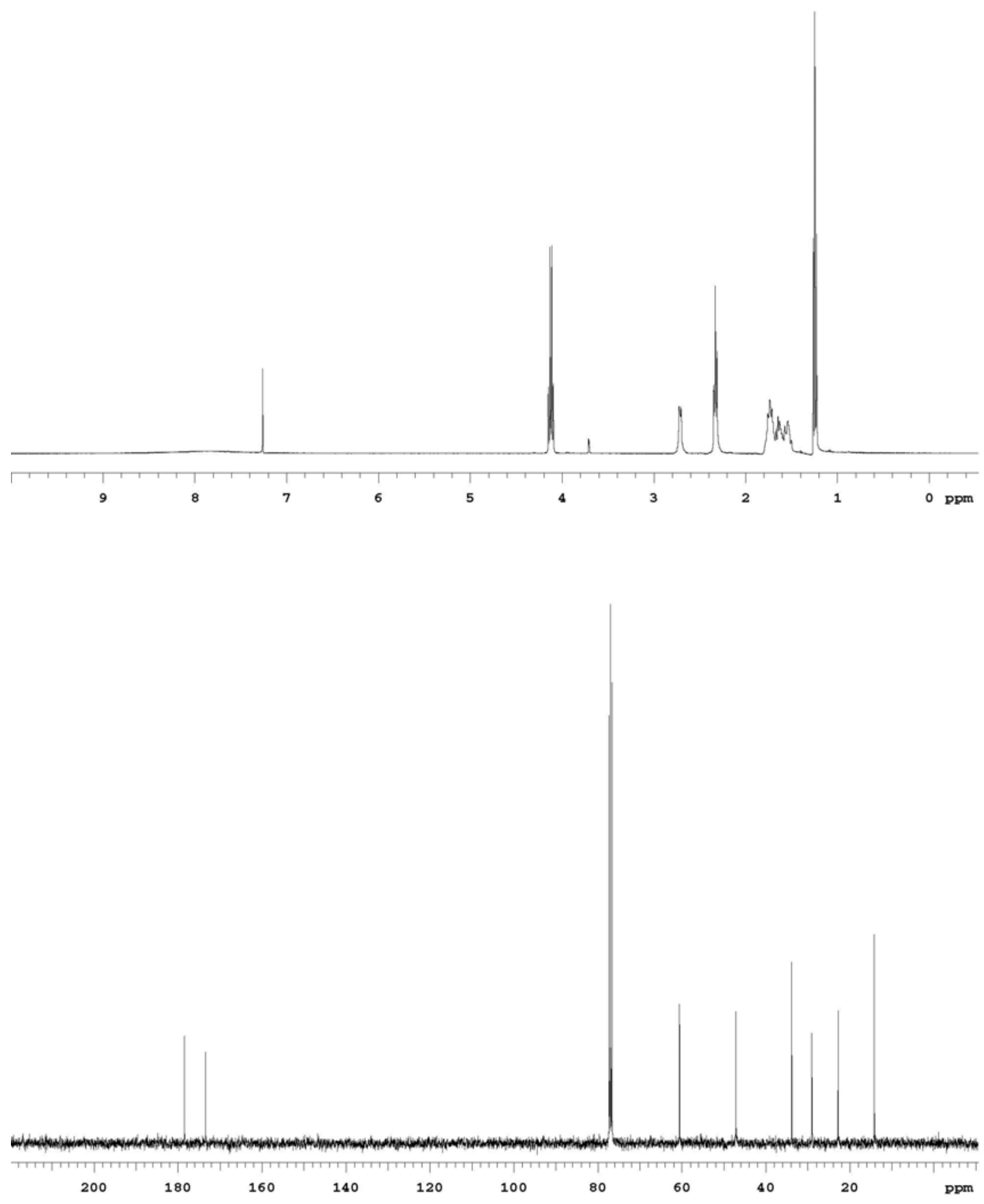
${ }^{1} \mathrm{H}$ and ${ }^{13} \mathrm{C}$ sprectra for $\mathbf{4 6}$ :
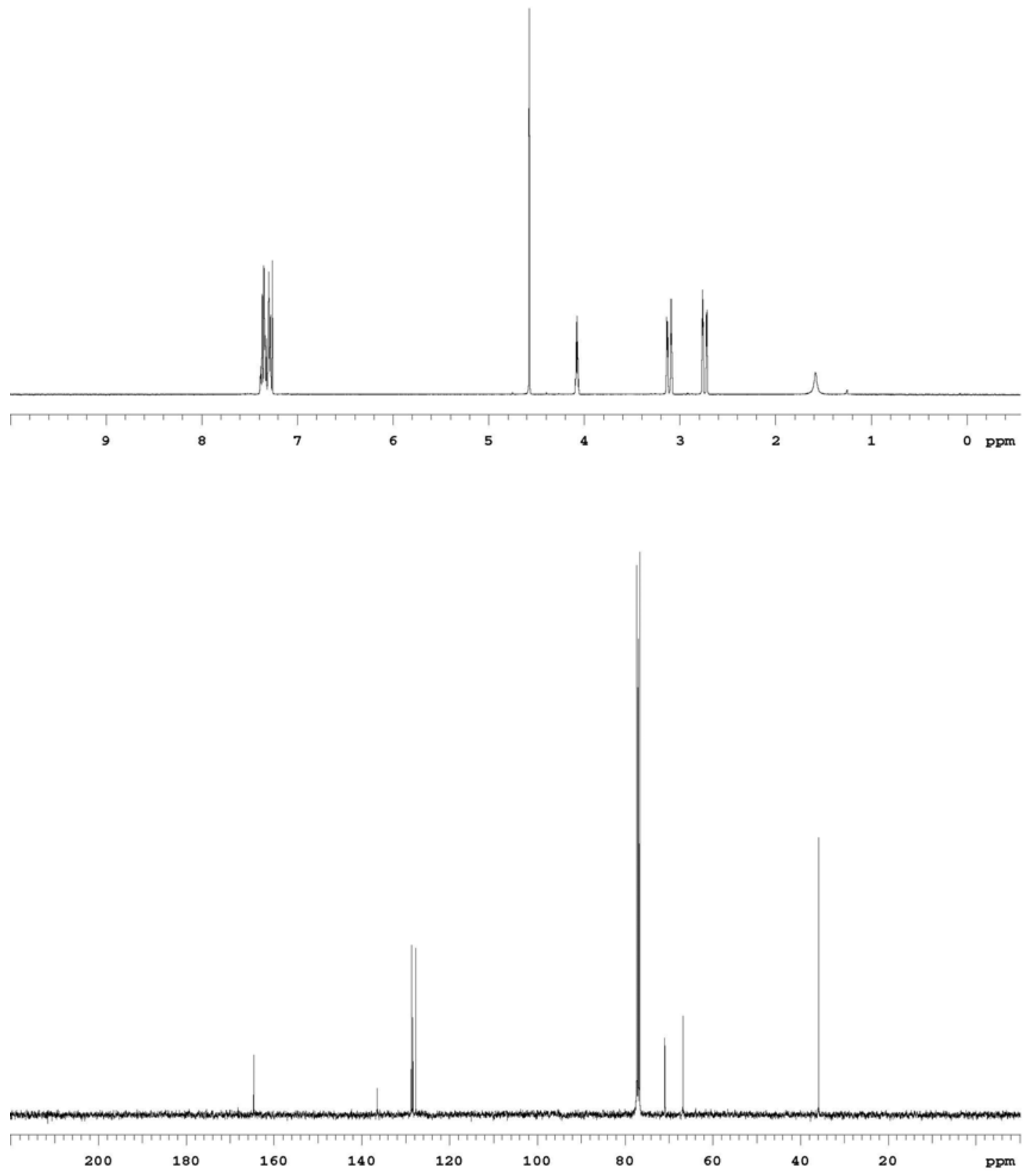
${ }^{1} \mathrm{H}$ and ${ }^{13} \mathrm{C}$ sprectra for $\mathbf{4 8}$ :
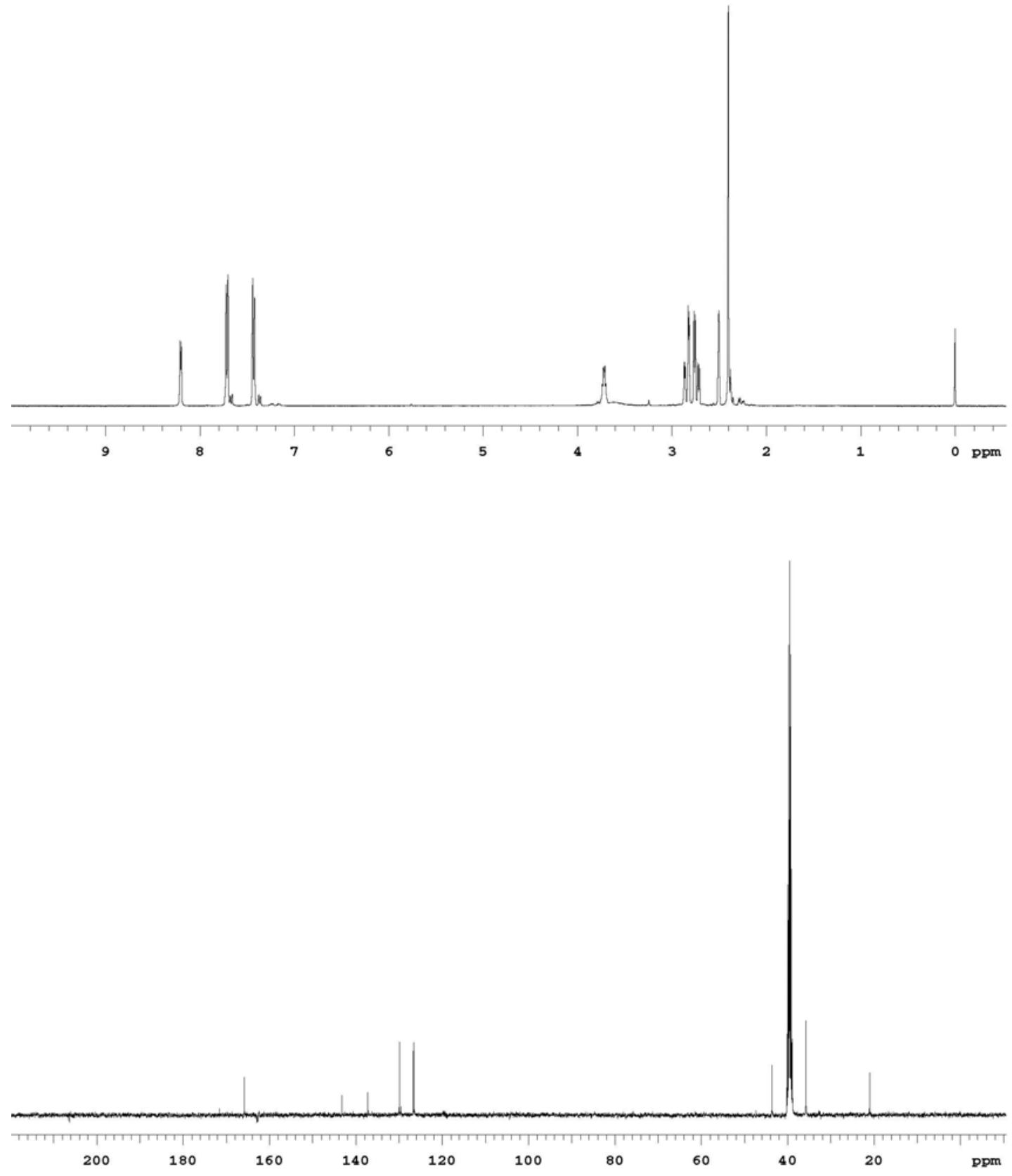
${ }^{1} \mathrm{H}$ and ${ }^{13} \mathrm{C}$ sprectra for $\mathbf{5 8}$ :
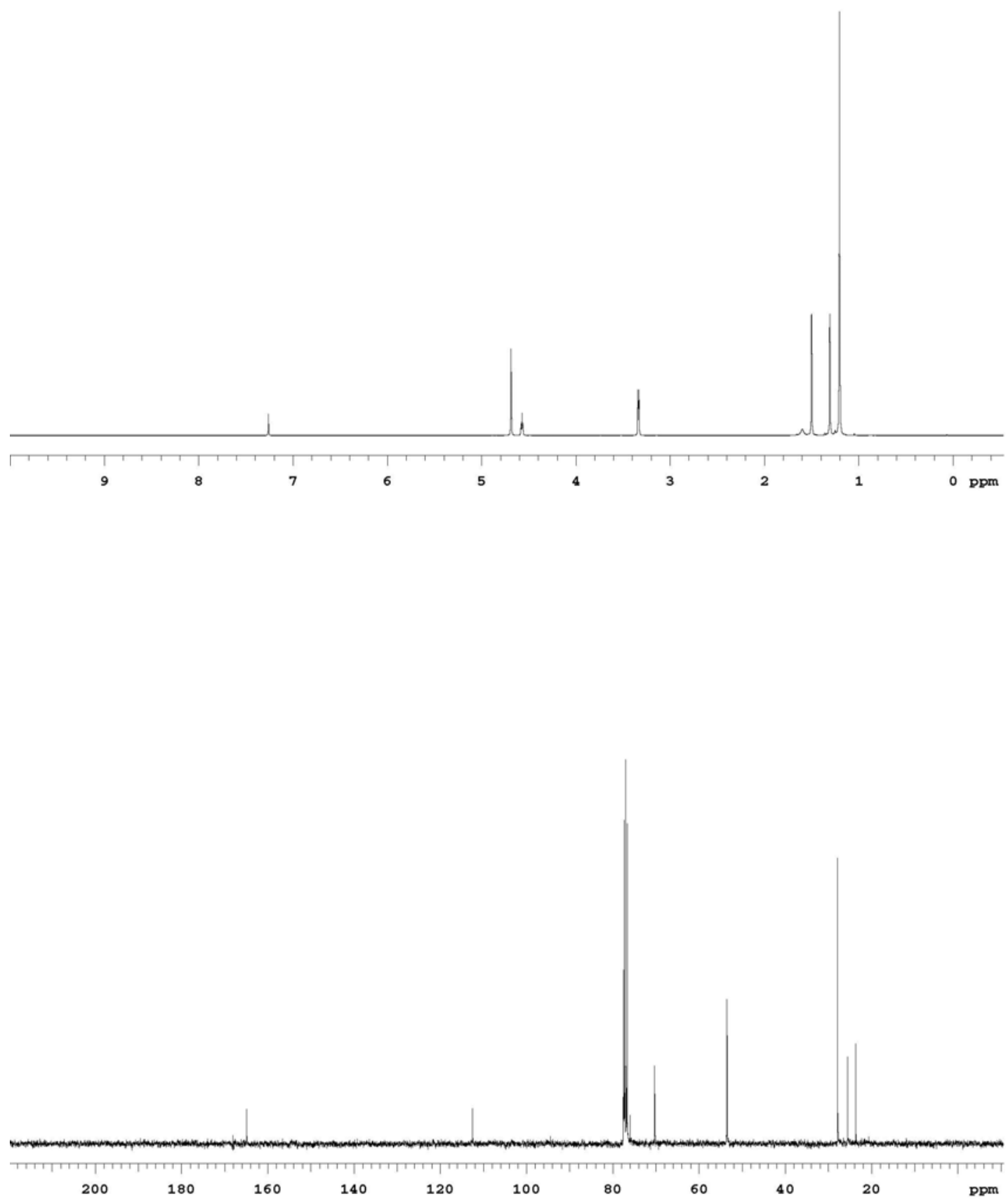
${ }^{1} \mathrm{H}$ and ${ }^{13} \mathrm{C}$ sprectra for $\mathbf{1 0}$ :
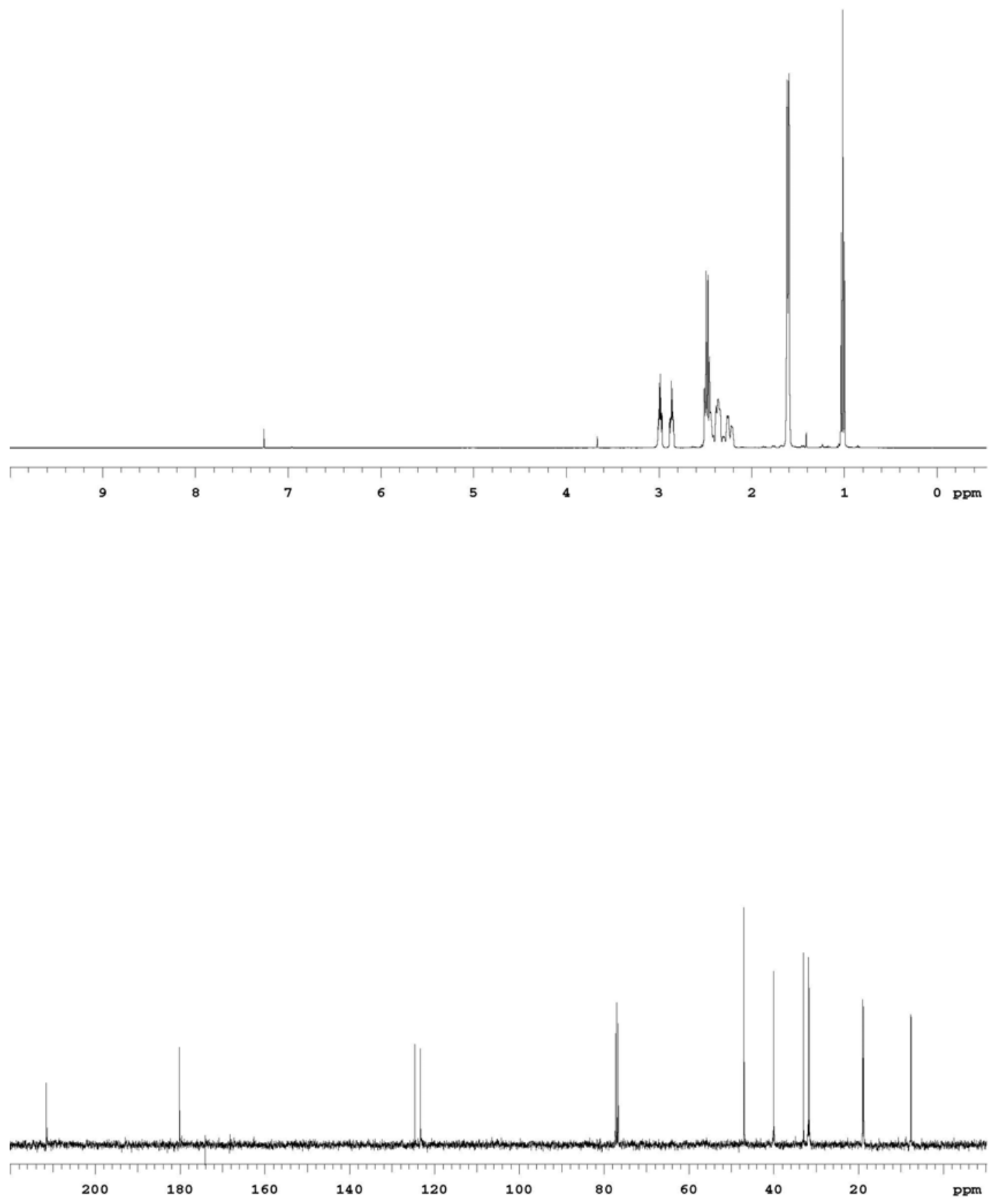
${ }^{1} \mathrm{H}$ and ${ }^{13} \mathrm{C}$ sprectra for $\mathbf{1 3}$ :
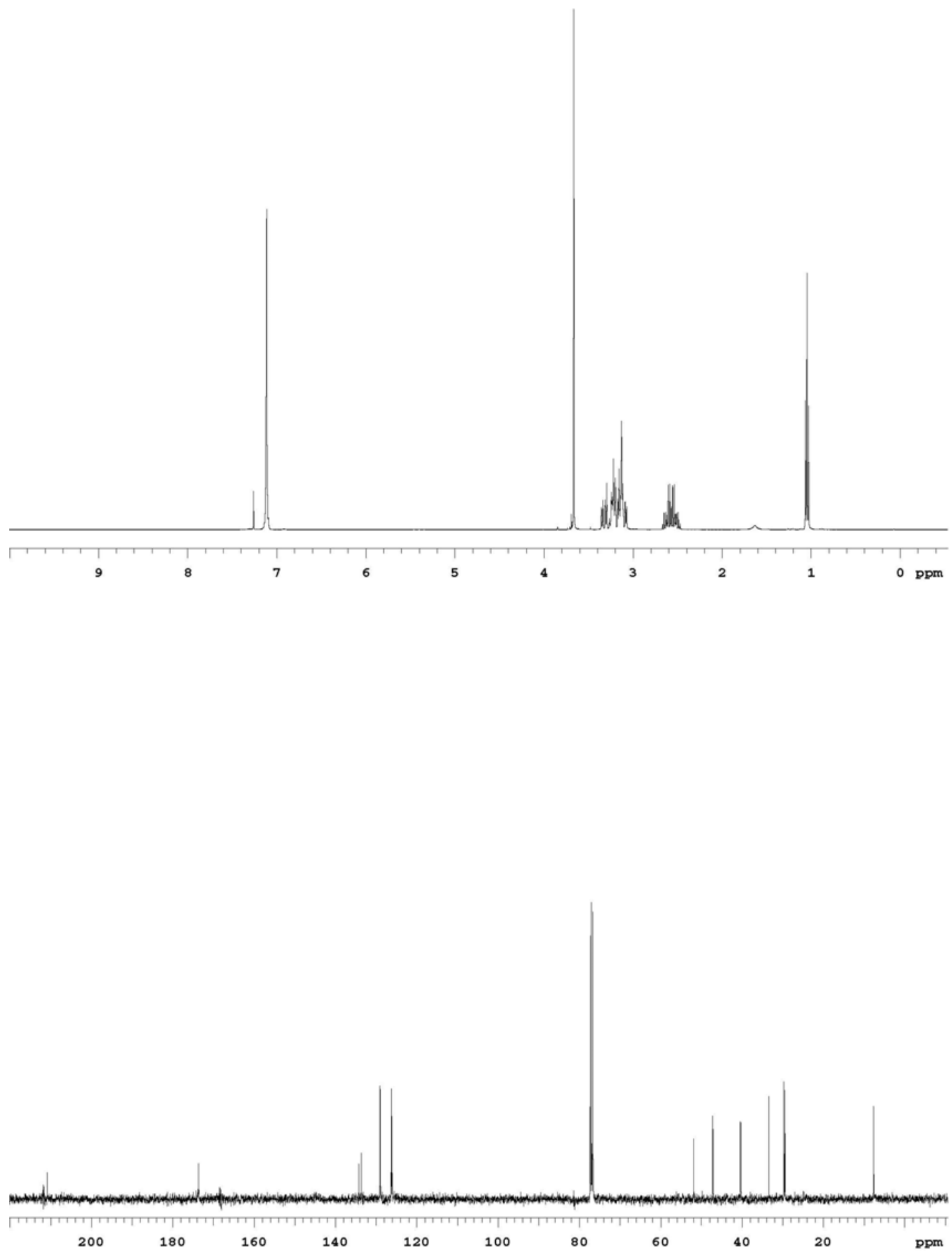
${ }^{1} \mathrm{H}$ and ${ }^{13} \mathrm{C}$ sprectra for $\mathbf{1 5}$ :
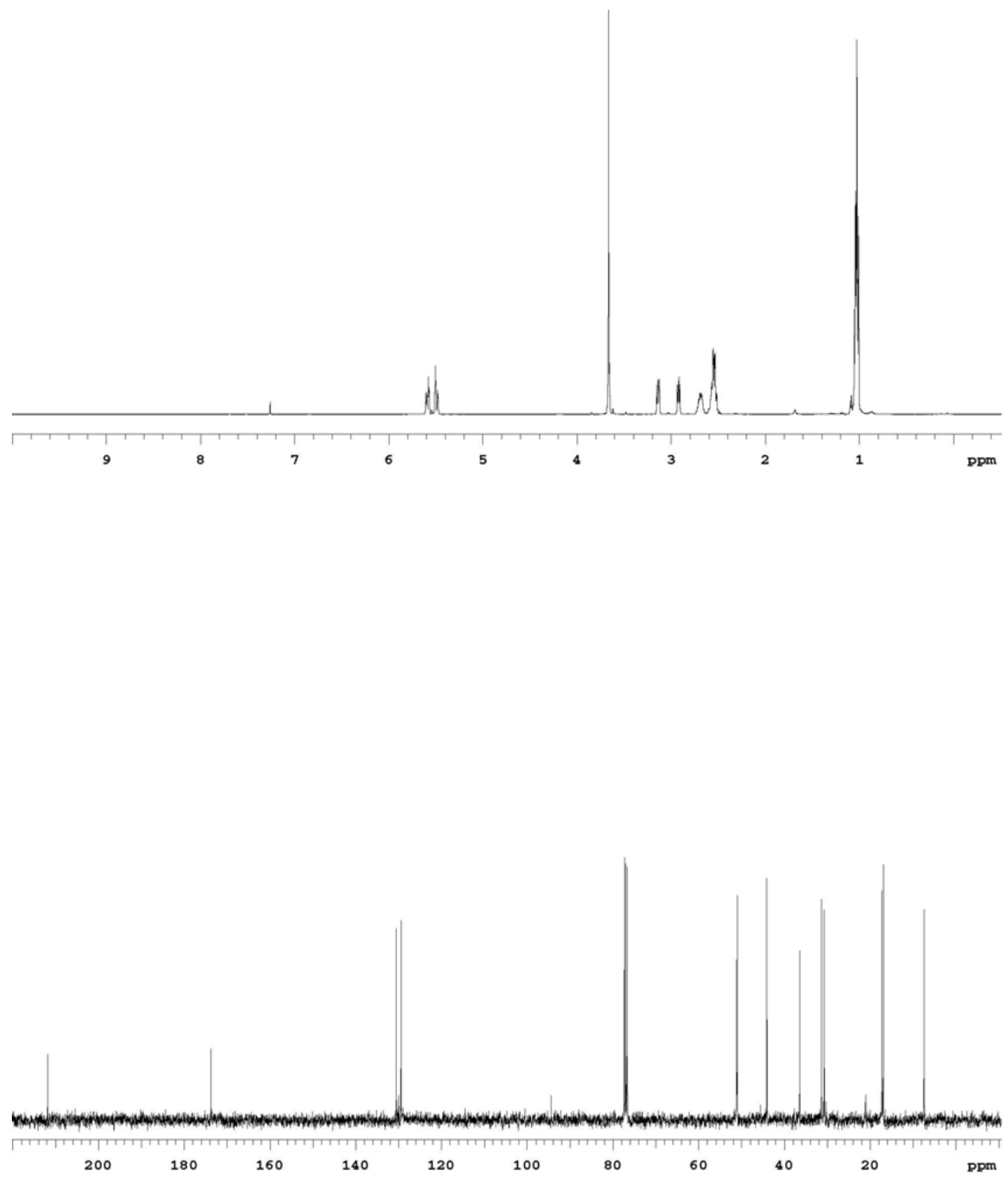
${ }^{1} \mathrm{H}$ and ${ }^{13} \mathrm{C}$ sprectra for $\mathbf{1 7}$ :
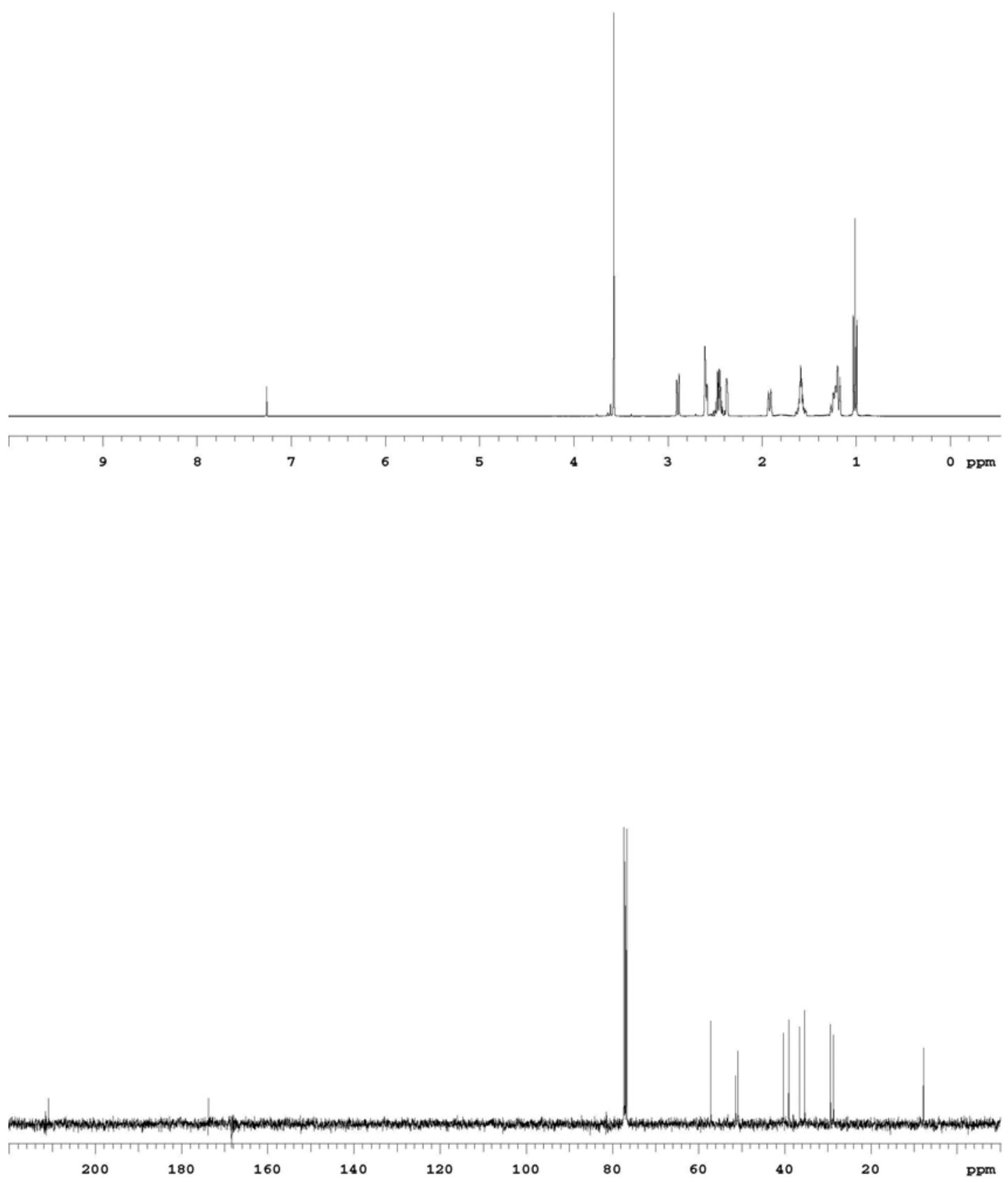
${ }^{1} \mathrm{H}$ and ${ }^{13} \mathrm{C}$ sprectra for $\mathbf{2 5}$ :
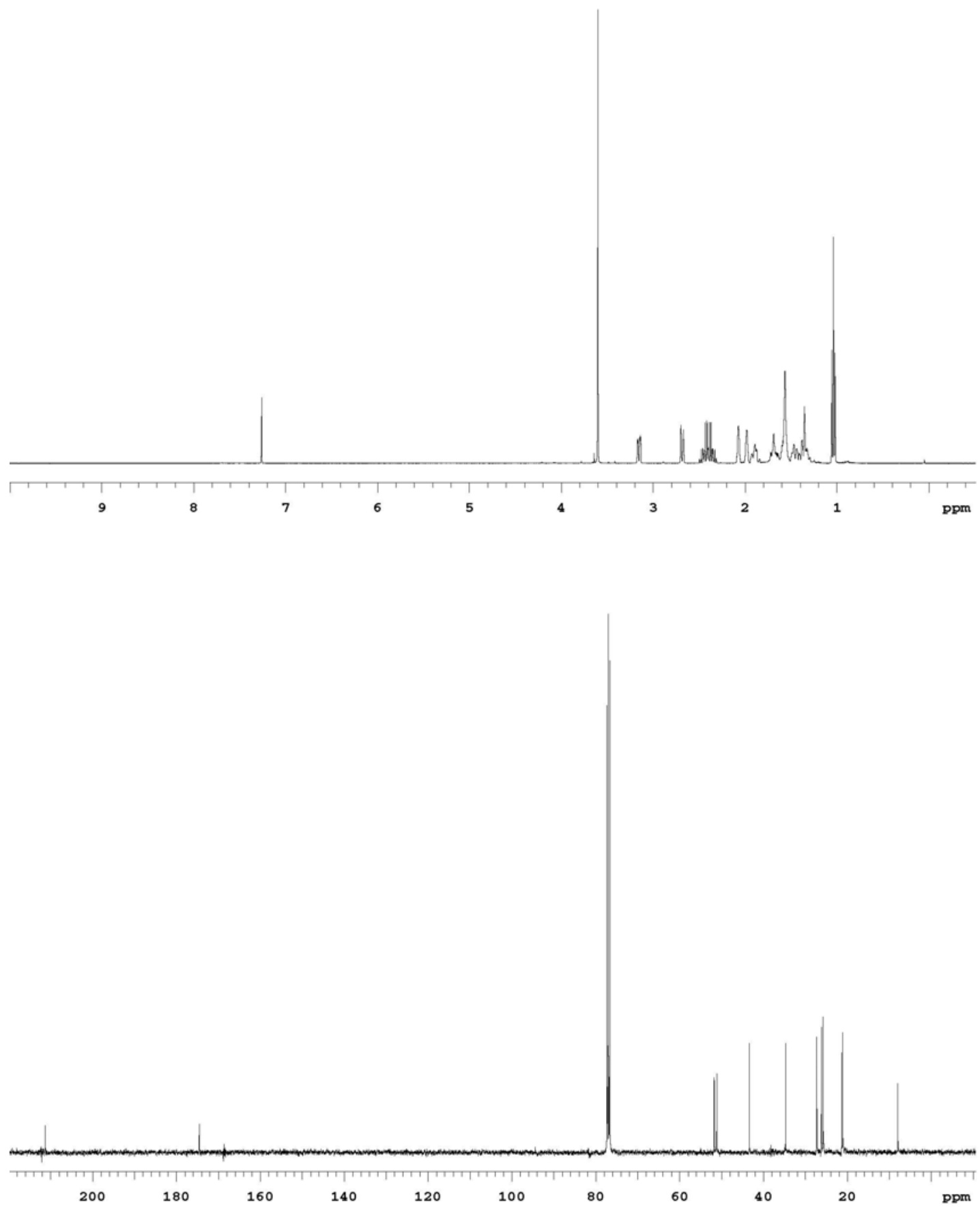
${ }^{1} \mathrm{H}$ and ${ }^{13} \mathrm{C}$ sprectra for $\mathbf{2 7}$ :
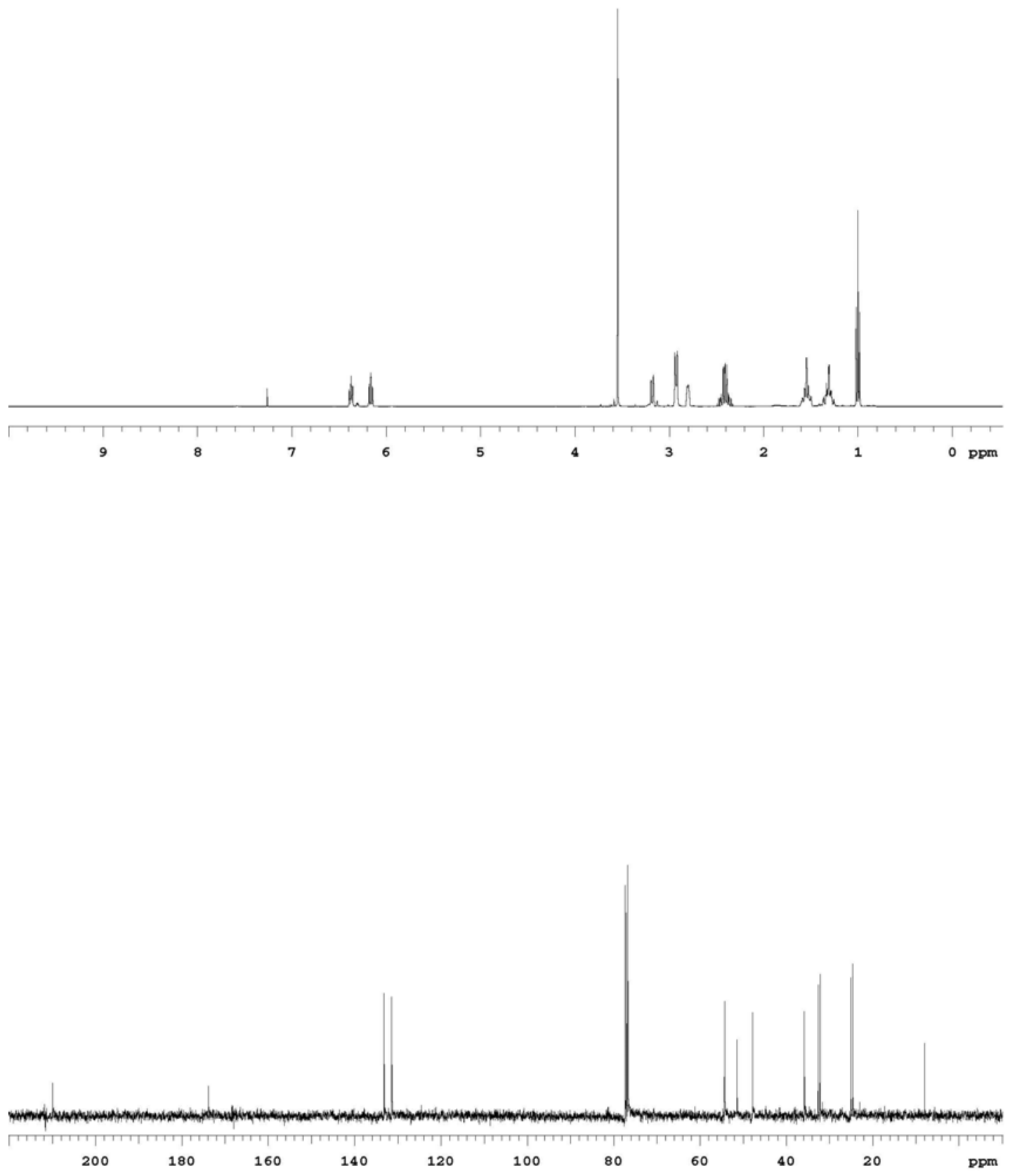
${ }^{1} \mathrm{H}$ and ${ }^{13} \mathrm{C}$ sprectra for $\mathbf{2 9}$ :
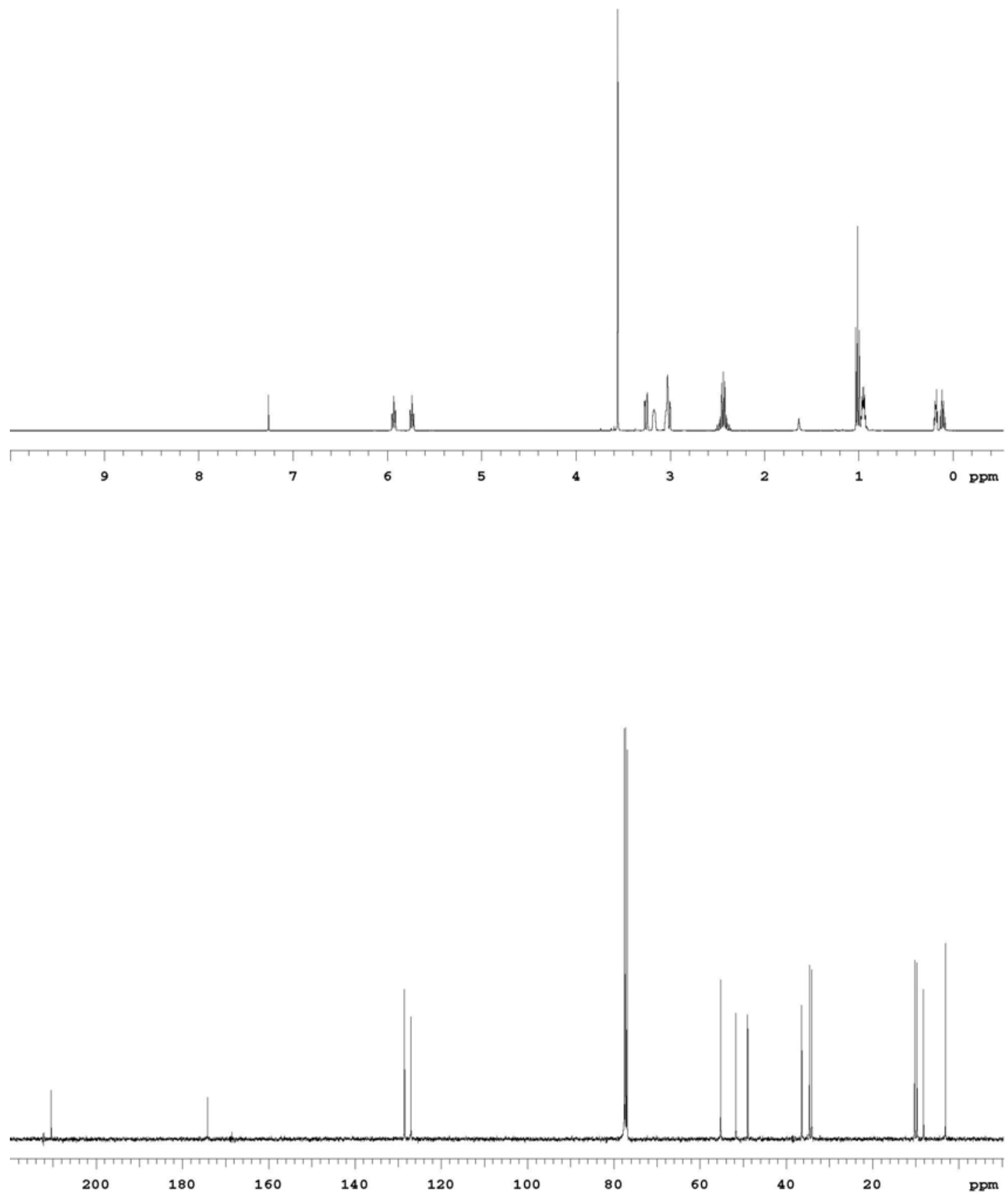
${ }^{1} \mathrm{H}$ and ${ }^{13} \mathrm{C}$ sprectra for $\mathbf{3 1}$ :
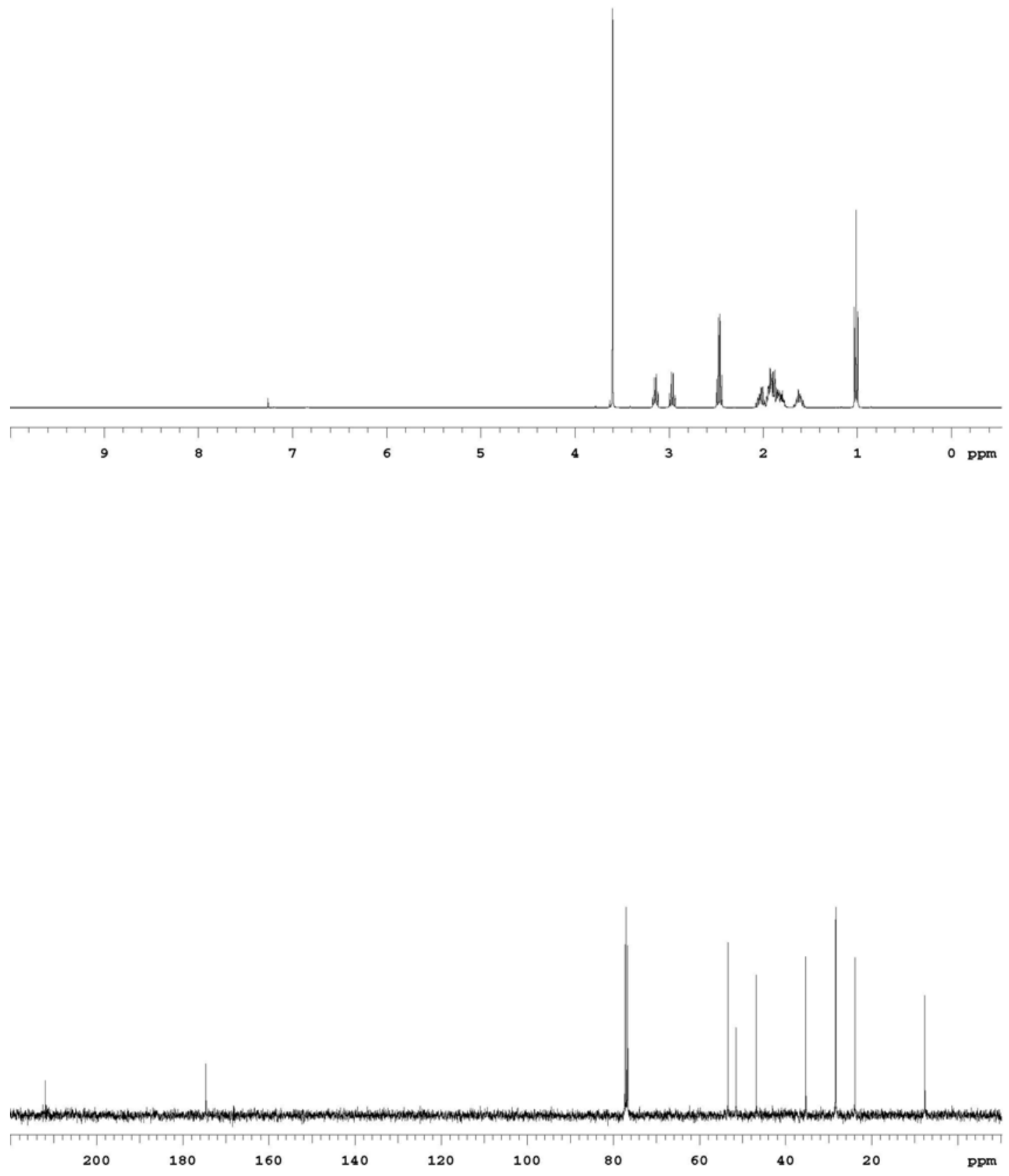
${ }^{1} \mathrm{H}$ and ${ }^{13} \mathrm{C}$ sprectra for $\mathbf{3 5 :}$
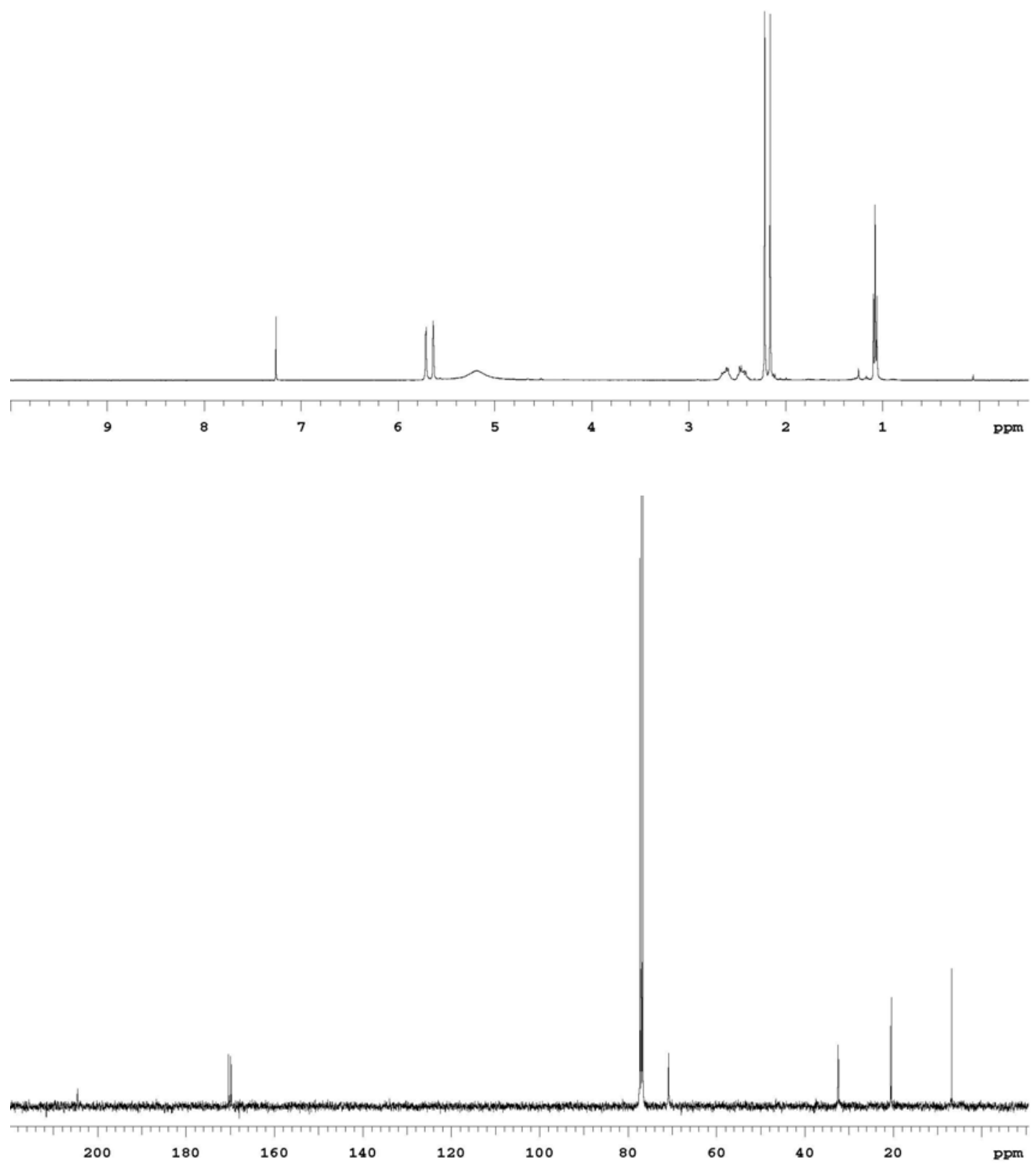
${ }^{1} \mathrm{H}$ and ${ }^{13} \mathrm{C}$ sprectra for $\mathbf{4 1}$ :
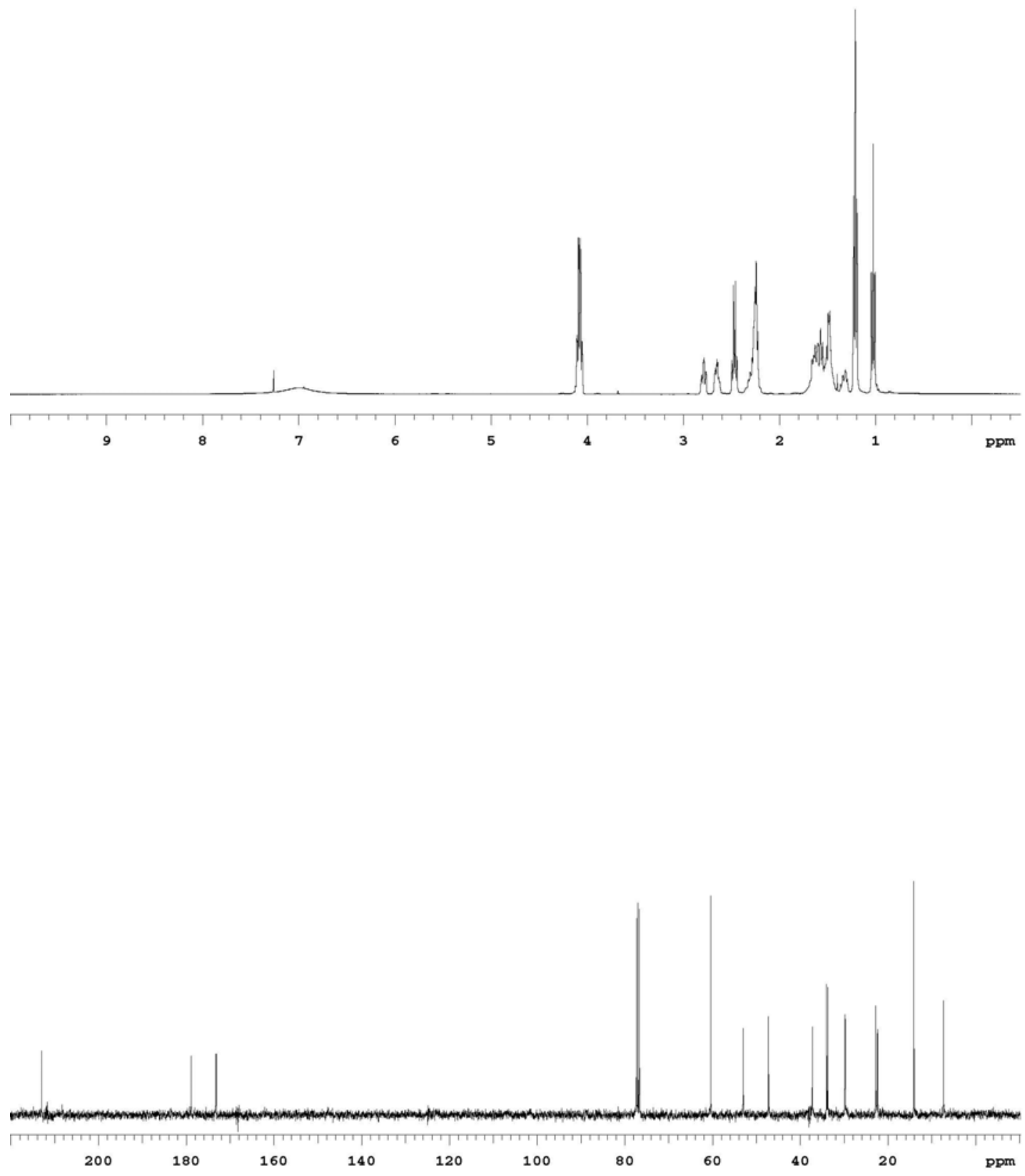
${ }^{1} \mathrm{H}$ and ${ }^{13} \mathrm{C}$ sprectra for $\mathbf{4 5}$ :
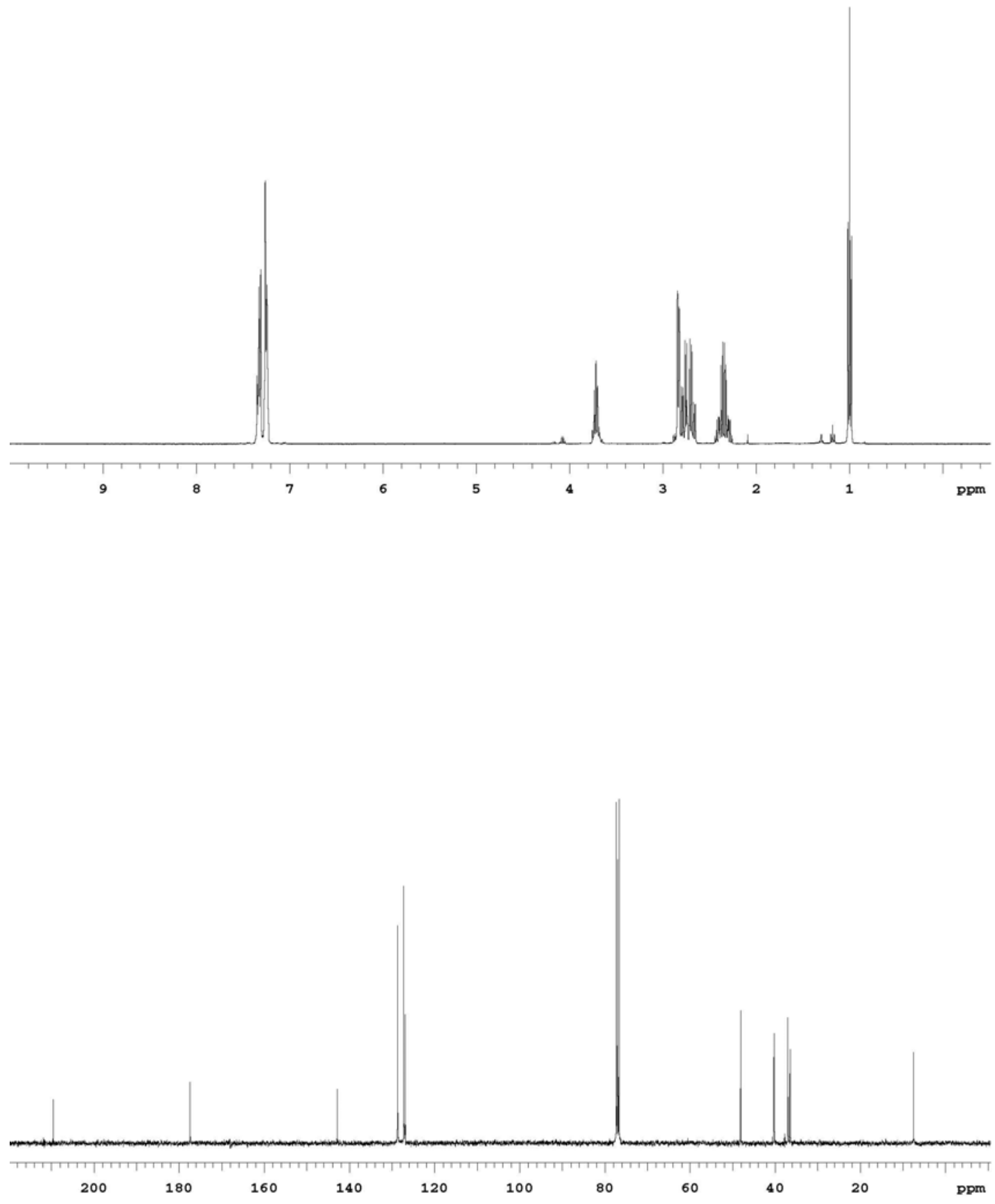
${ }^{1} \mathrm{H}$ and ${ }^{13} \mathrm{C}$ sprectra for $\mathbf{4 7}$ :
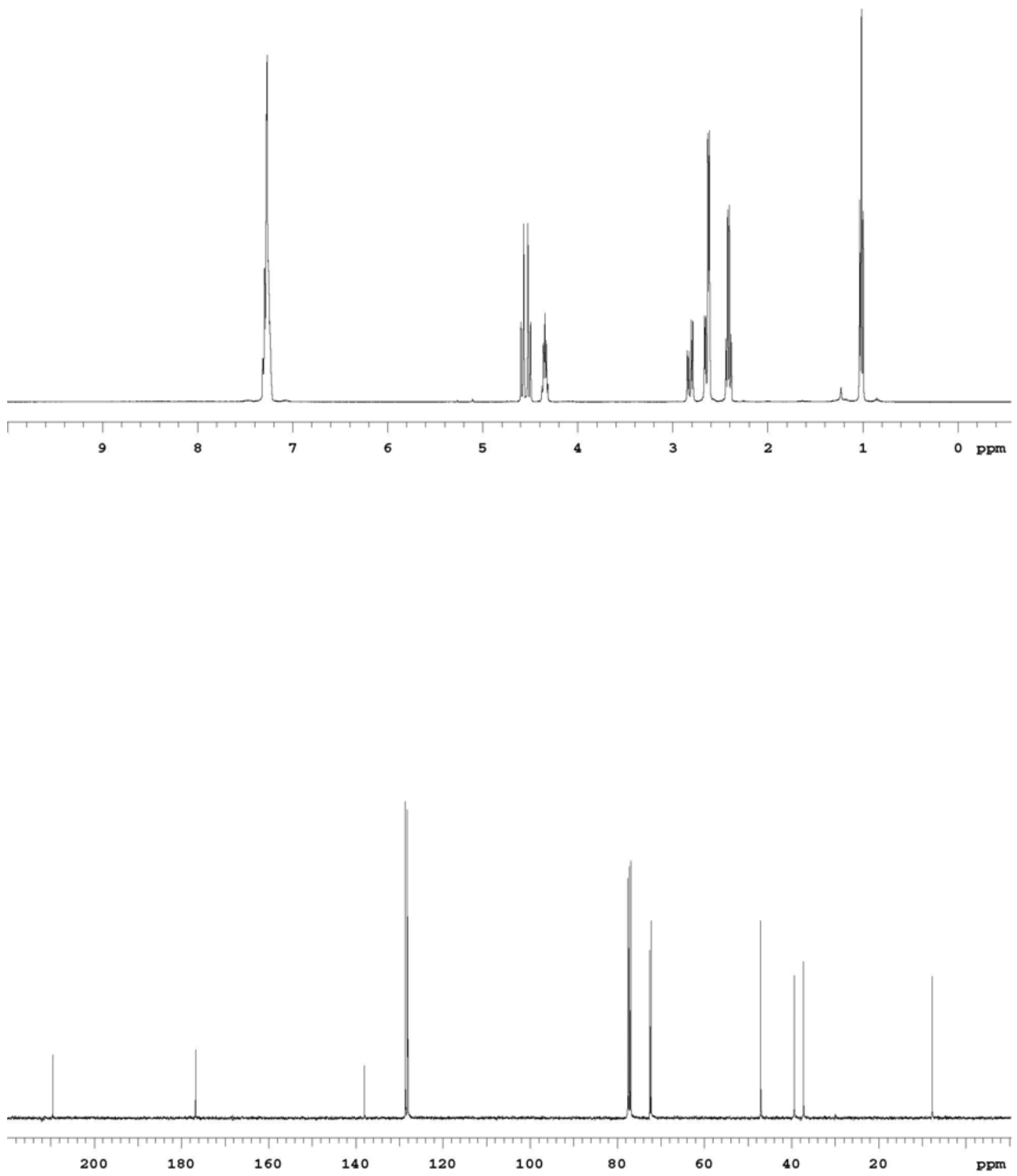
${ }^{1} \mathrm{H}$ and ${ }^{13} \mathrm{C}$ sprectra for $\mathbf{4 9}$ :
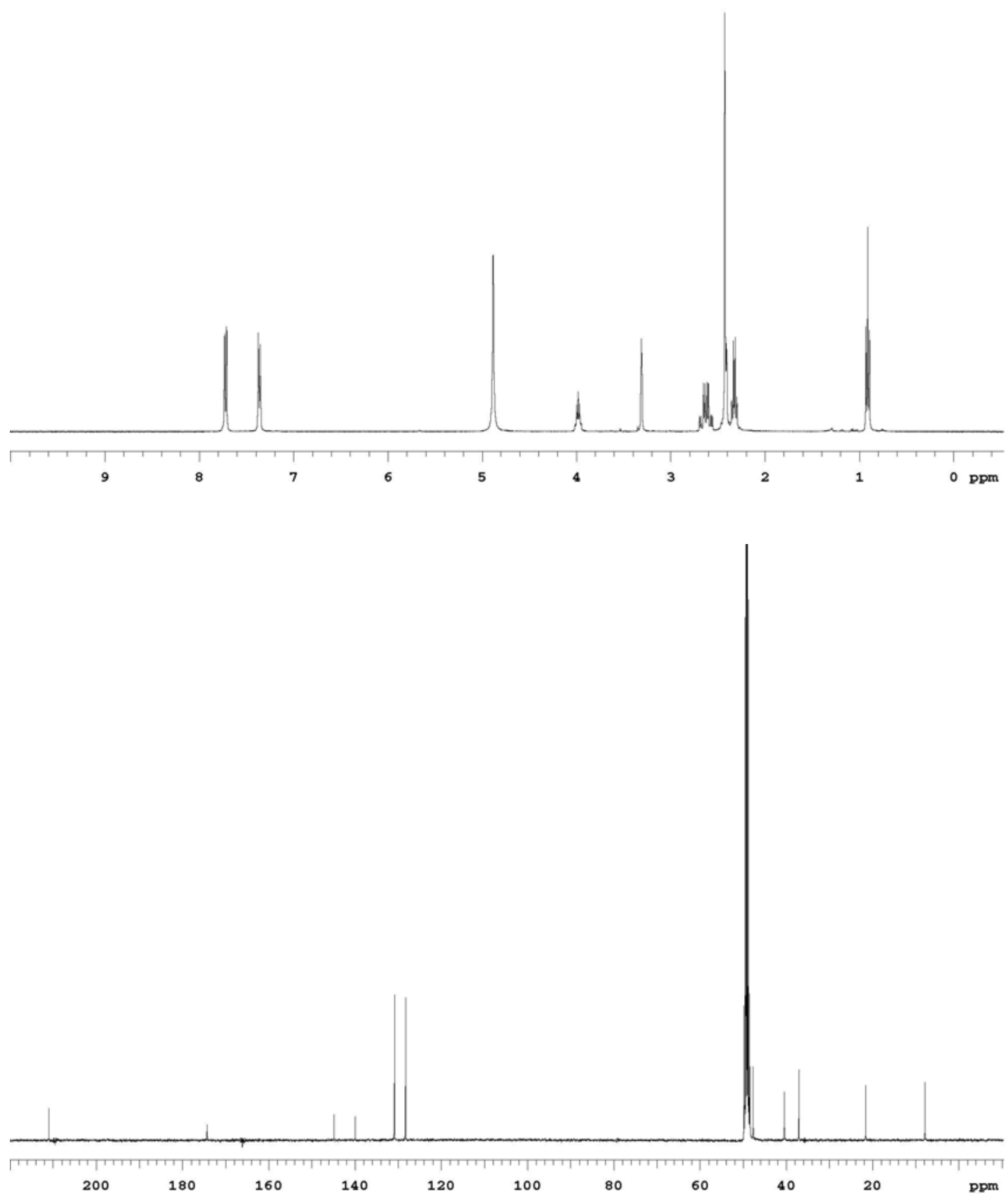
${ }^{1} \mathrm{H}$ and ${ }^{13} \mathrm{C}$ sprectra for $\mathbf{5 1}$ :
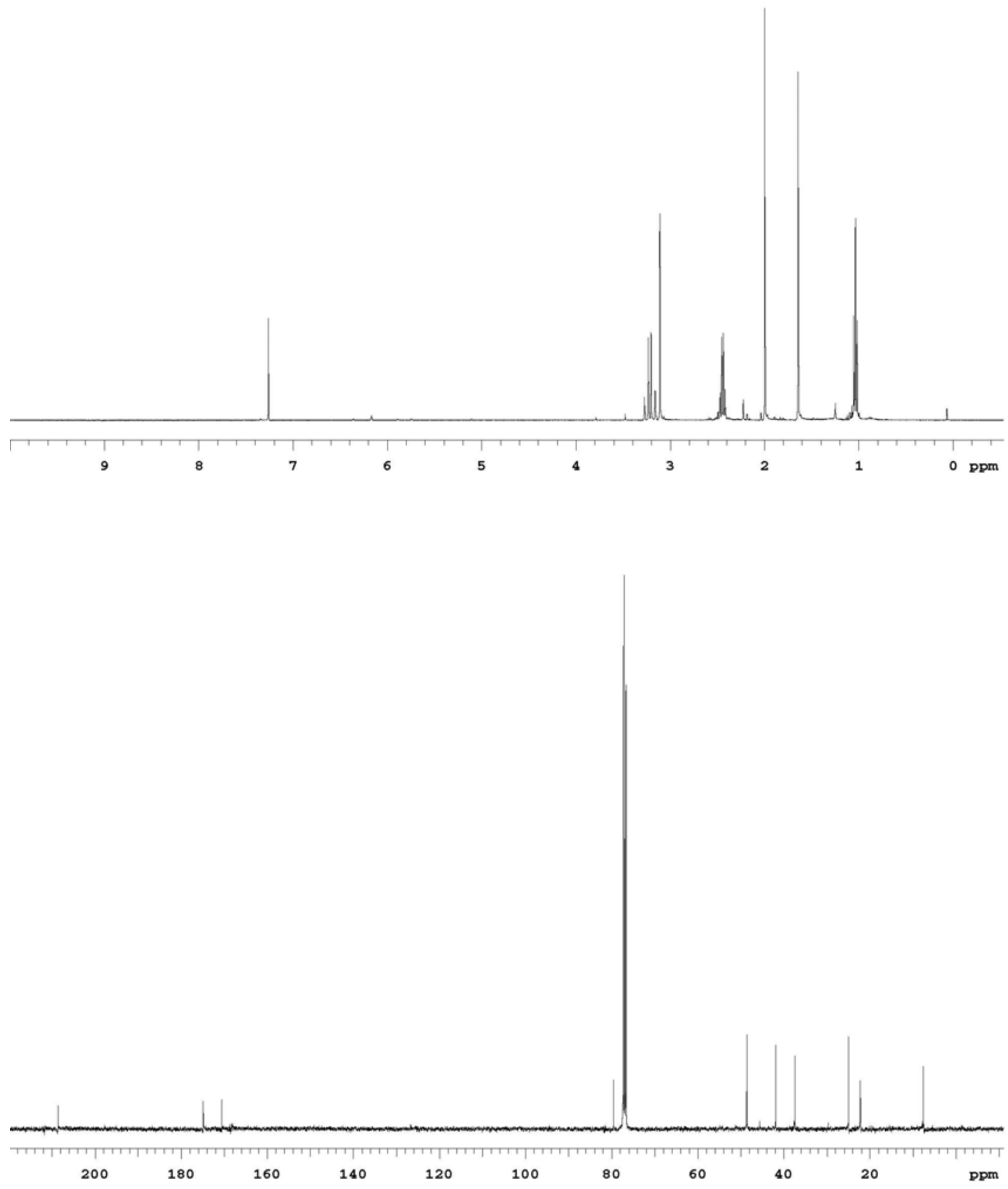
${ }^{1} \mathrm{H}$ and ${ }^{13} \mathrm{C}$ sprectra for $\mathbf{5 3}$ :
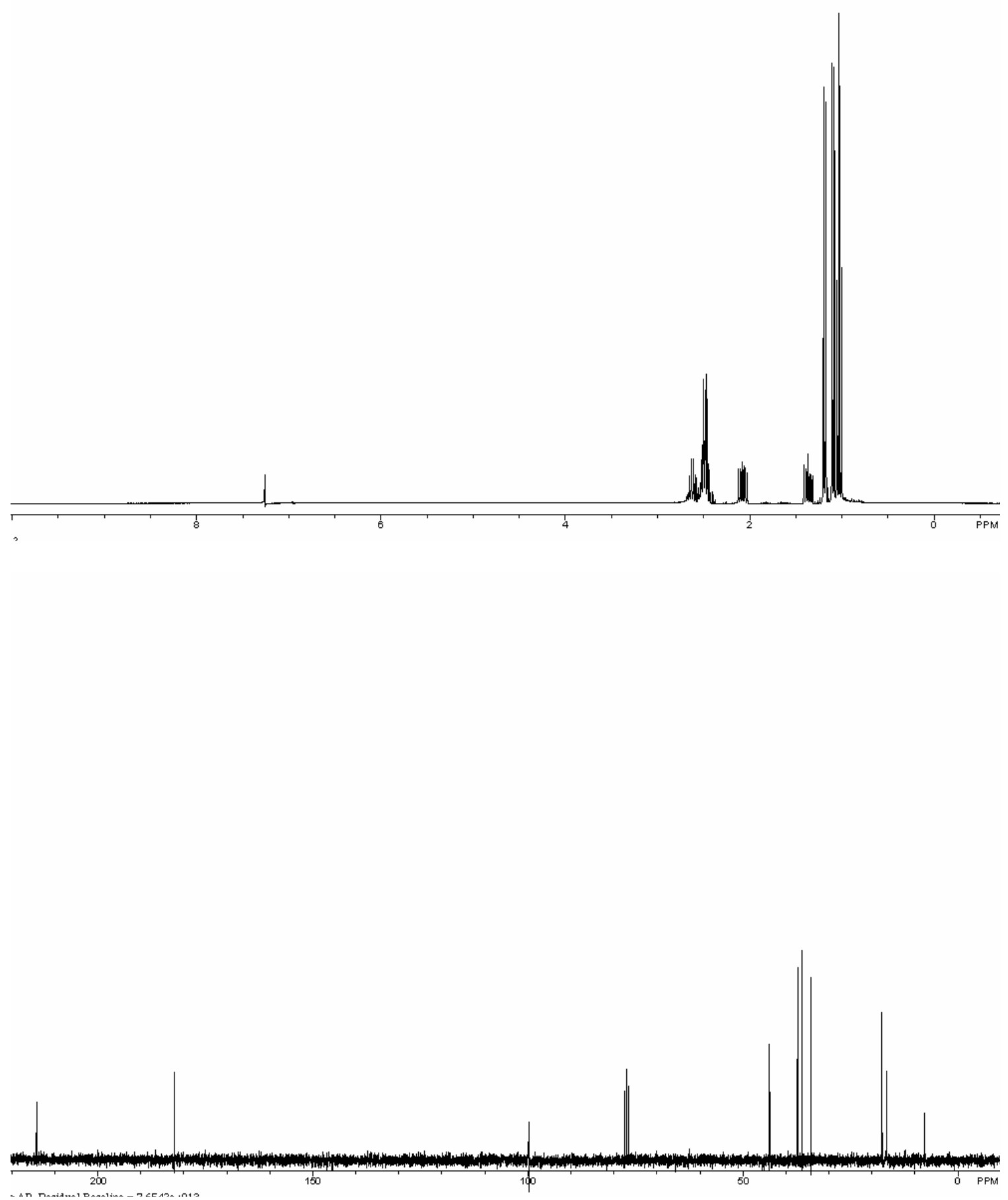
${ }^{1} \mathrm{H}$ and ${ }^{13} \mathrm{C}$ sprectra for $\mathbf{5 5}$ :
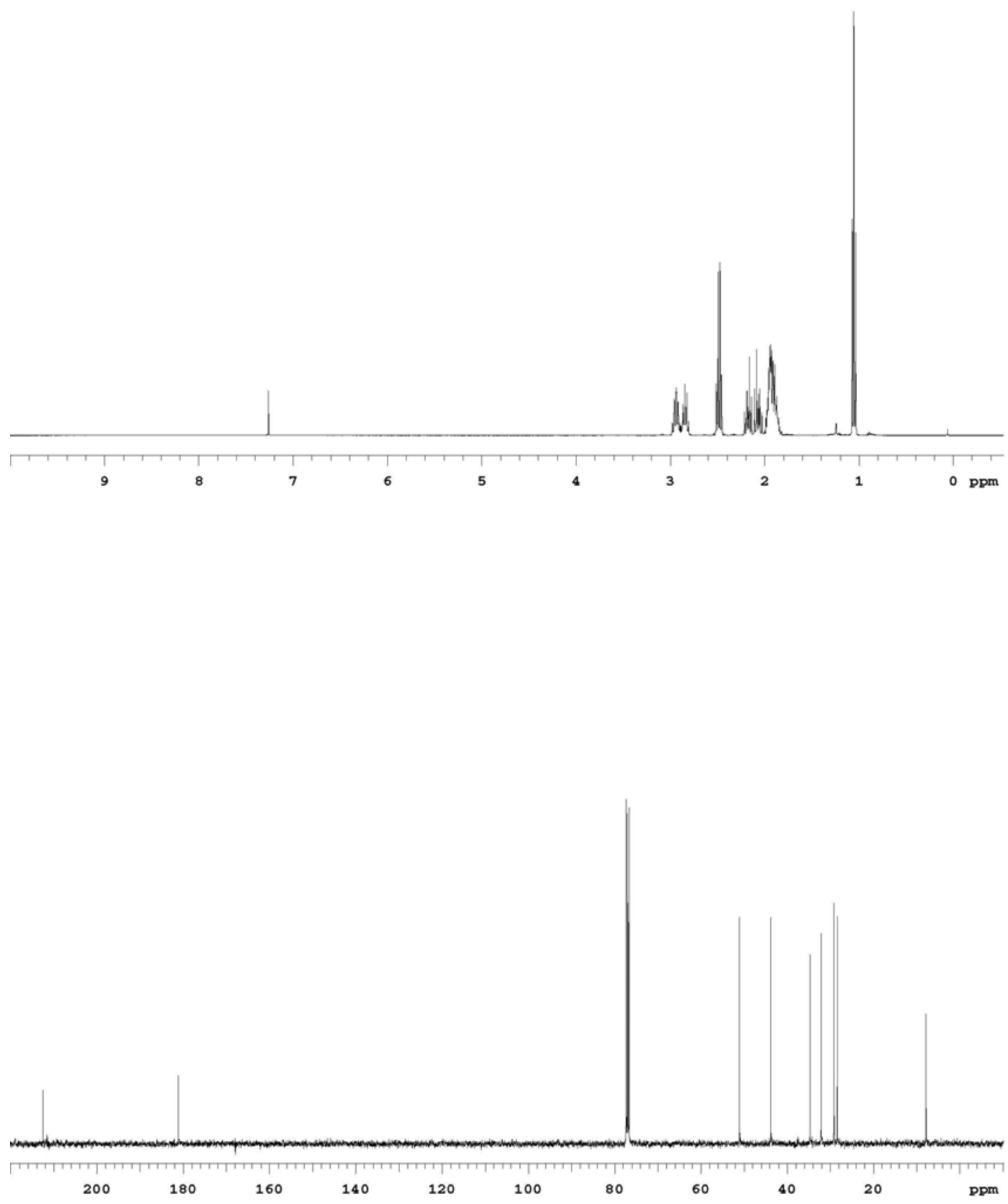
${ }^{1} \mathrm{H}$ and ${ }^{13} \mathrm{C}$ sprectra for $\mathbf{5 7}$ :
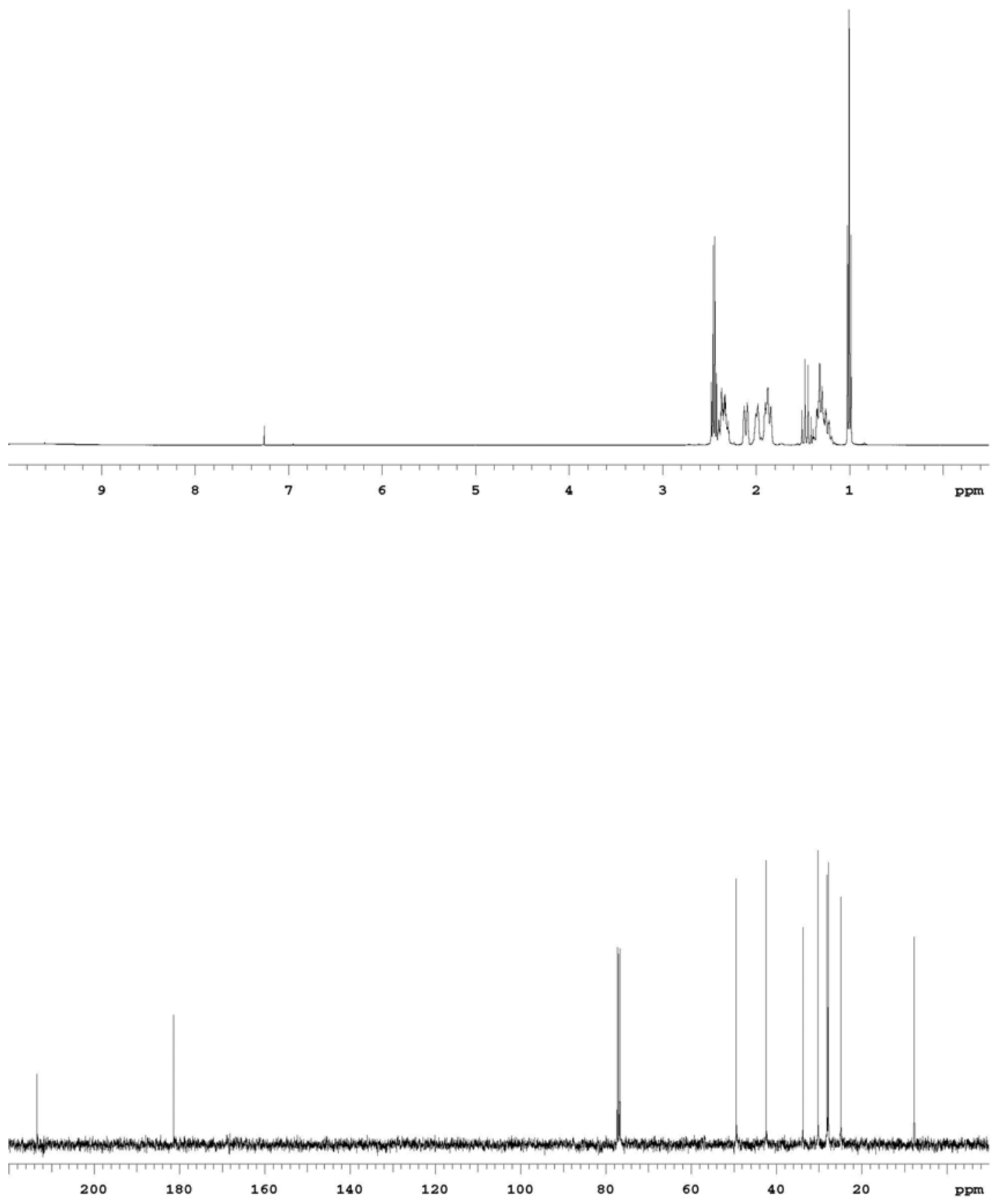
${ }^{1} \mathrm{H}$ and ${ }^{13} \mathrm{C}$ sprectra for $\mathbf{5 9}$ :
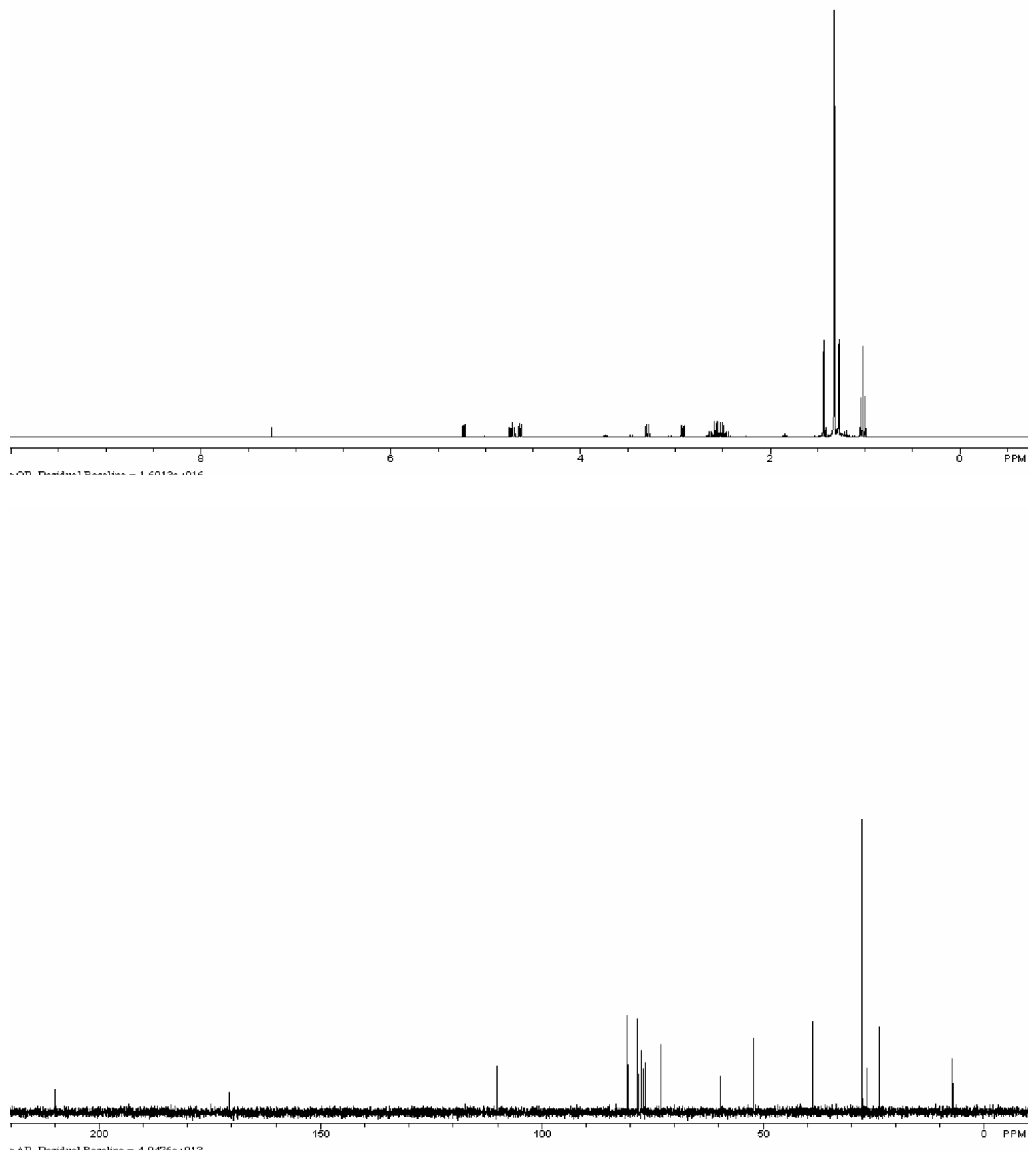
${ }^{1} \mathrm{H}$ and ${ }^{13} \mathrm{C}$ sprectra for $\mathbf{S 1 1}$ :
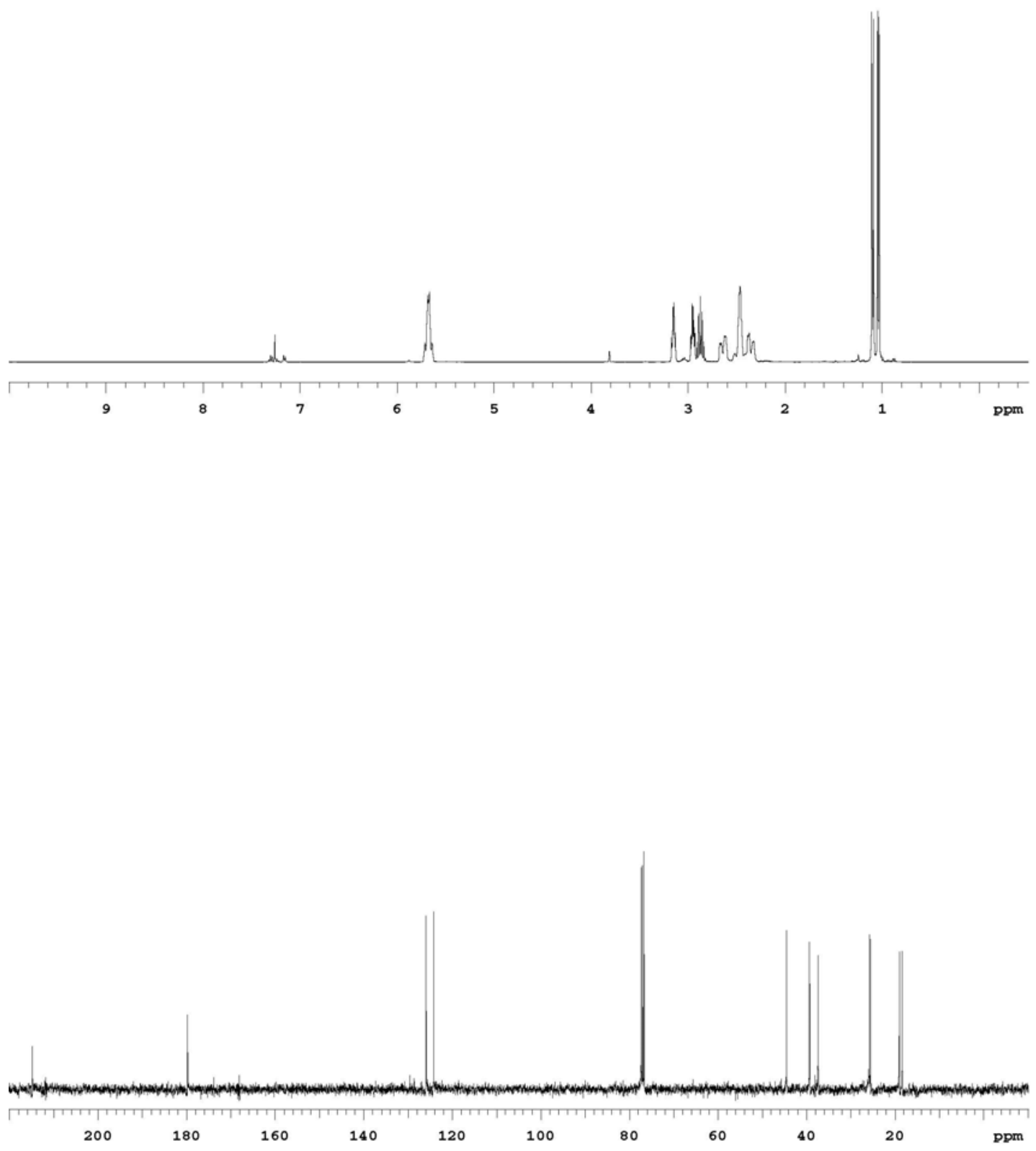
${ }^{1} \mathrm{H}$ and ${ }^{13} \mathrm{C}$ sprectra for S16:
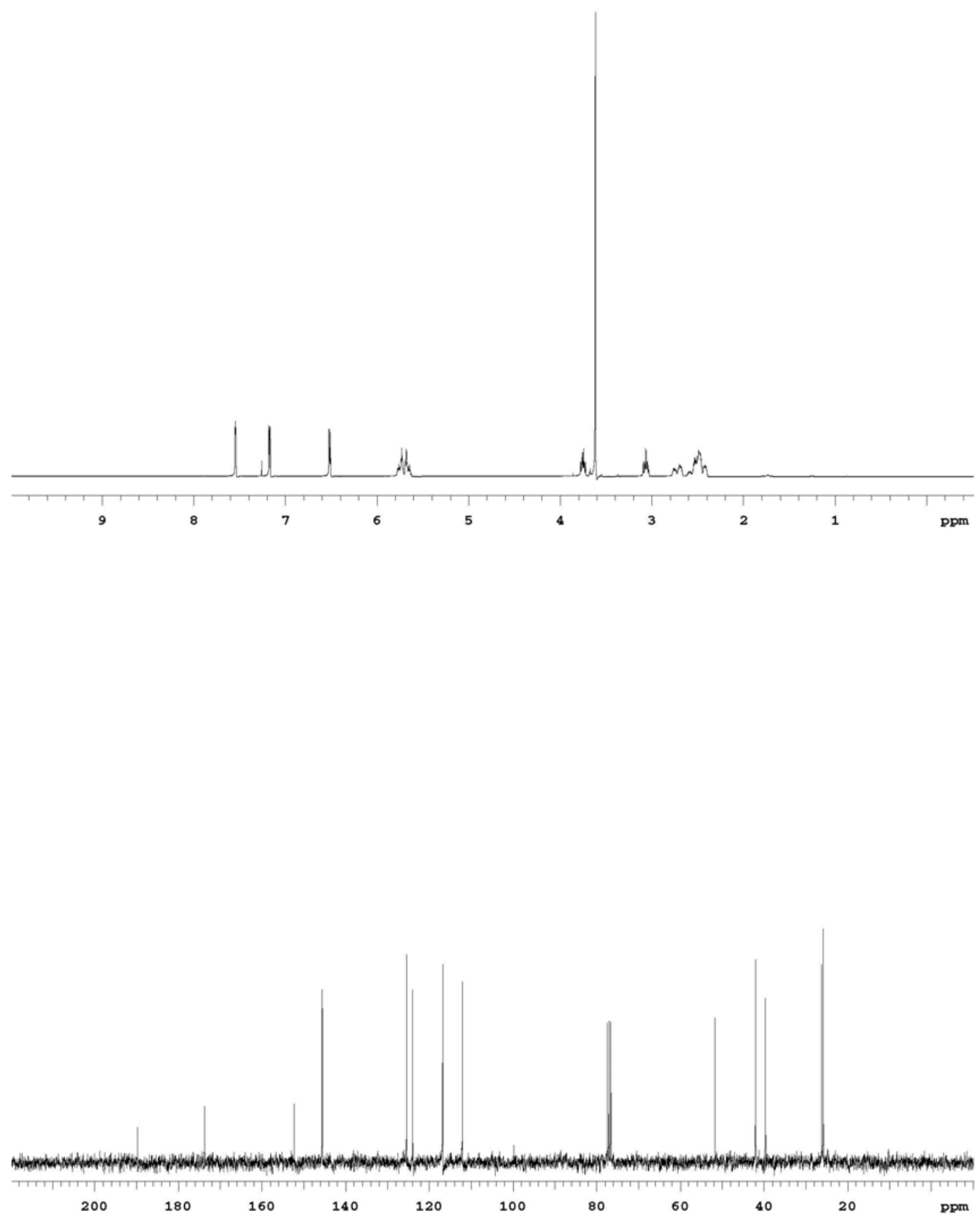
${ }^{1} \mathrm{H}$ and ${ }^{13} \mathrm{C}$ sprectra for S17:
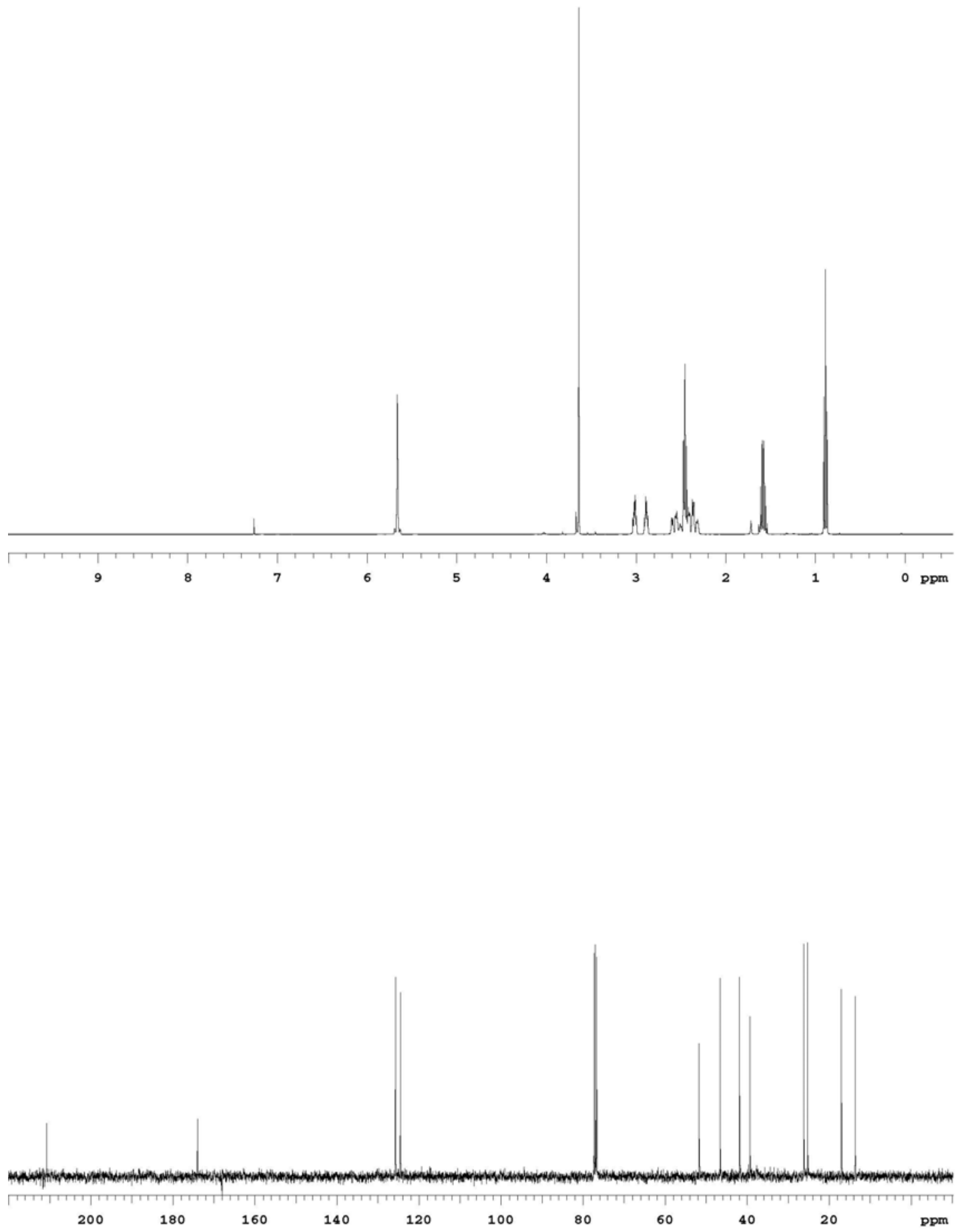
${ }^{1} \mathrm{H}$ and ${ }^{13} \mathrm{C}$ sprectra for S18:
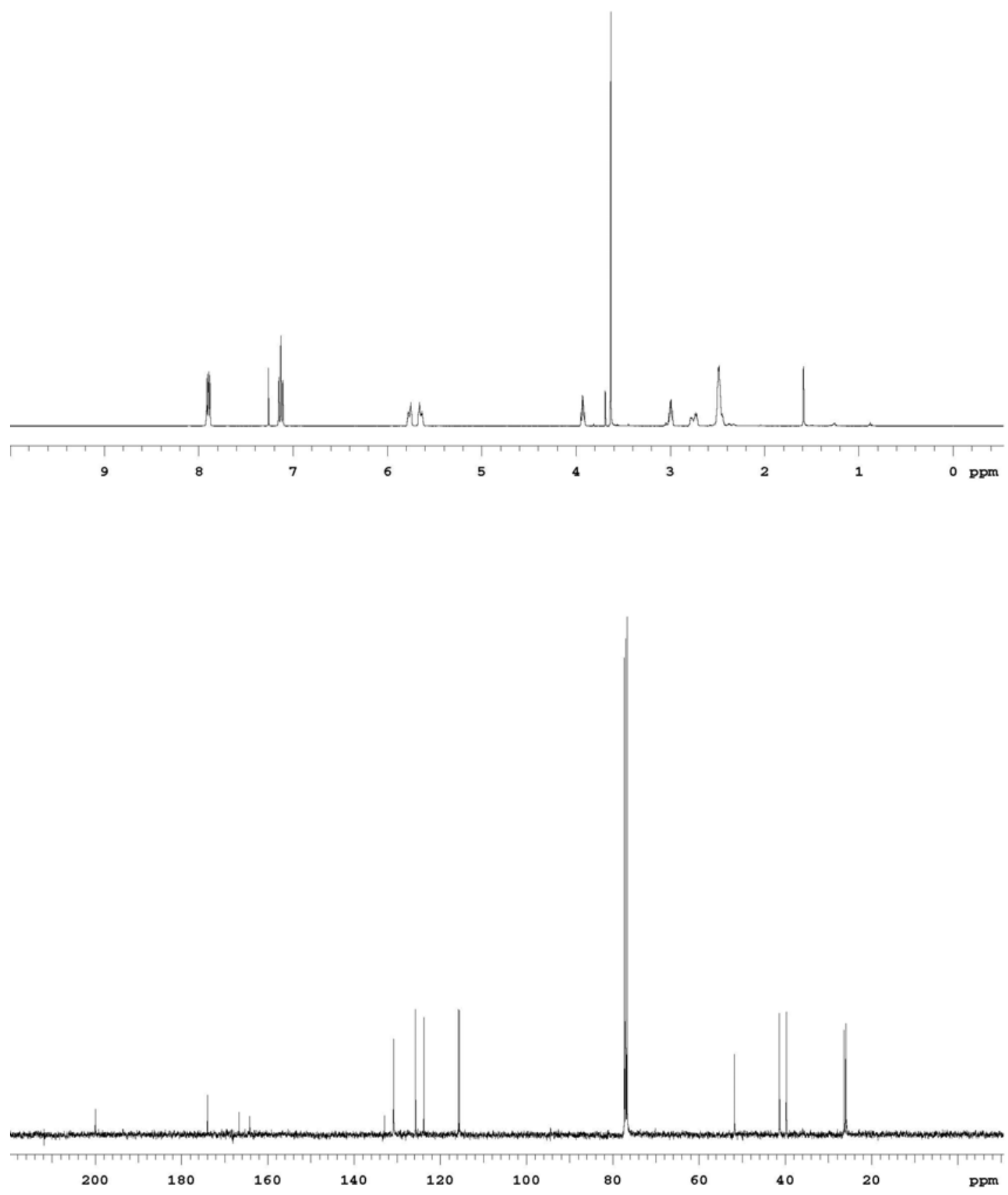
${ }^{1} \mathrm{H}$ and ${ }^{13} \mathrm{C}$ sprectra for S19:
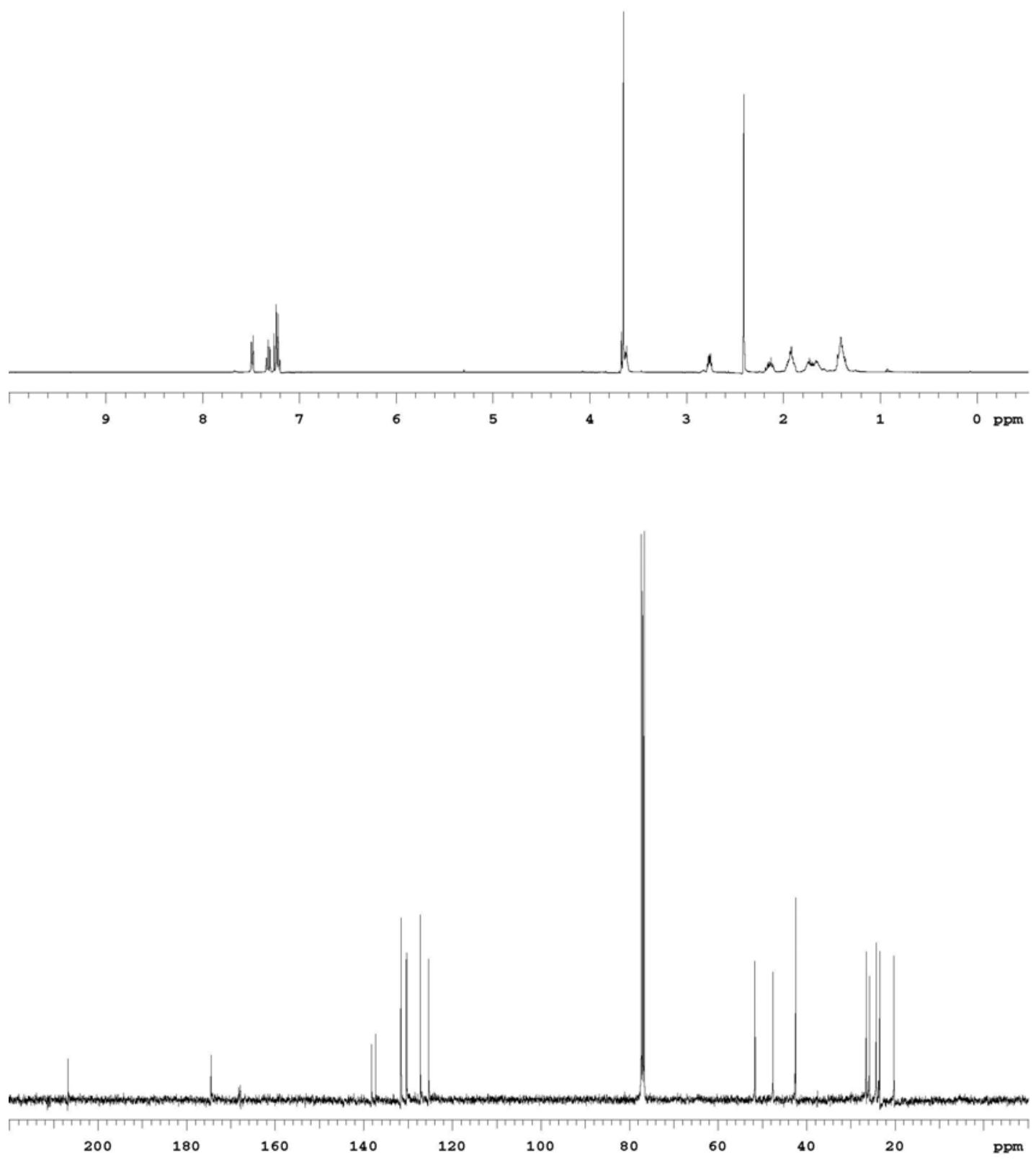
${ }^{1} \mathrm{H}$ and ${ }^{13} \mathrm{C}$ sprectra for $\mathbf{S 2 0}$ :
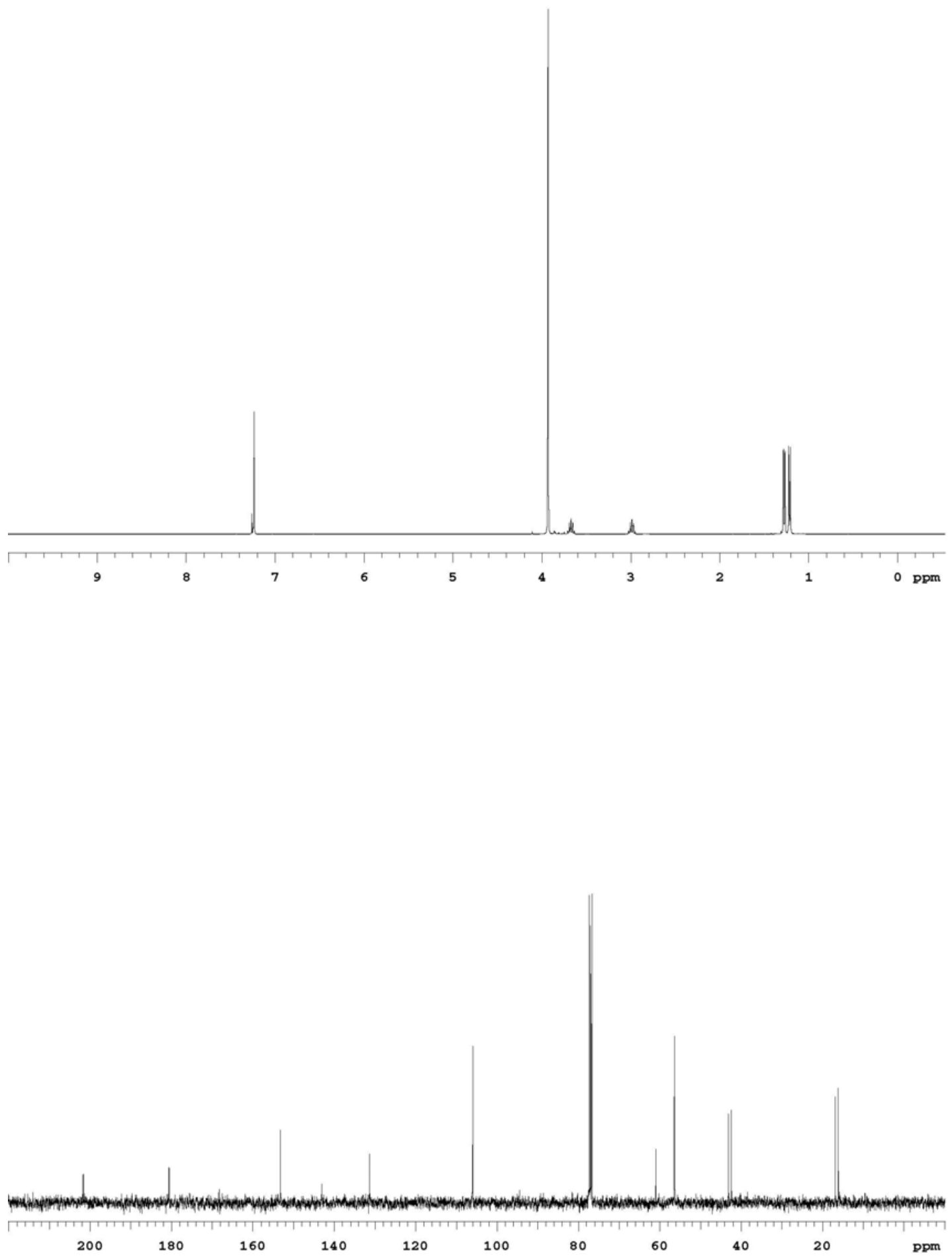
${ }^{1} \mathrm{H}$ and ${ }^{13} \mathrm{C}$ sprectra for $\mathbf{S 2 1 :}$
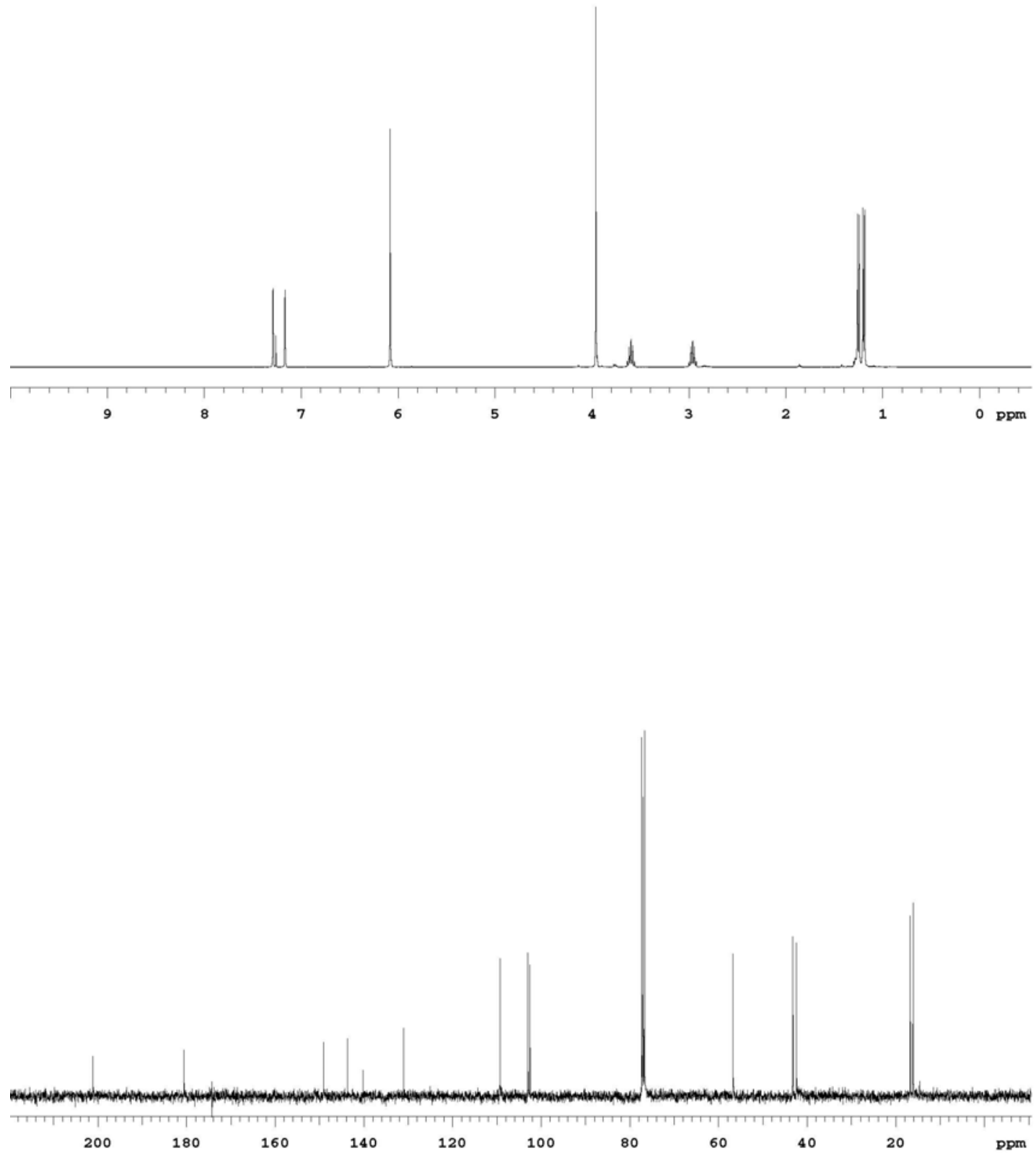